ORNL/TM-2005/xx

\title{
MATERIALS FABRICATED FOR FUTURIX-MI EXPERIMENT
}

Yutai Katoh, Thak-Sang Byun and Randy K. Nanstad

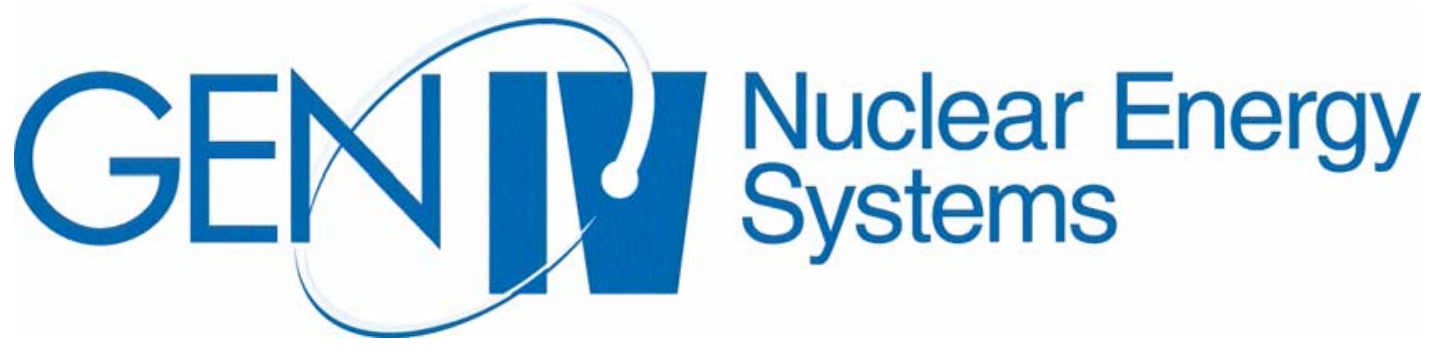

May 1, 2005 


\section{MATERIALS FABRICATED FOR FUTURIX-MI EXPERIMENT}

Yutai Katoh, Thak-Sang Byun and Randy K. Nanstad

May 1, 2005

Prepared for

Office of Nuclear Energy Science and Technology

Prepared by

OAK RIDGE NATIONAL LABORATORY

Oak Ridge, Tennessee 37831

managed by

UT-BATTELLE, LLC

for the

U.S. DEPARTMENT OF ENERGY

Under DOE Contract No. DE-AC05-00OR22725 


\section{TABLE OF CONTENTS}

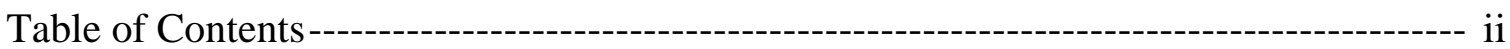

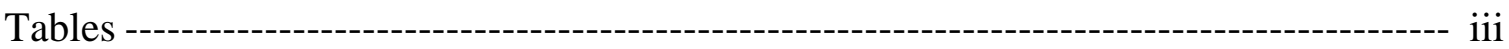

Acronyms---------------------------------------------------------------------------------- iv

Acknowledgments ---------------------------------------------------------------------- v

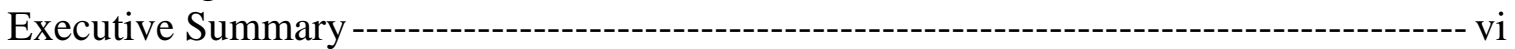

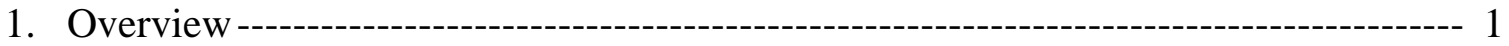

2. Key Schedule ----o- 1

3. ORNL Specimen Matrix ------------------------------------------------------ 2

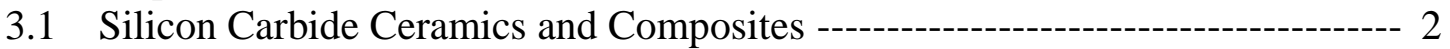

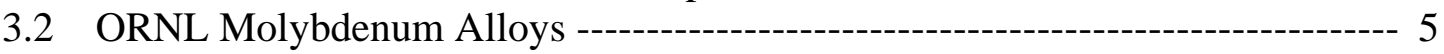

4. References ------- 7

Attachment 1: Futurix-MI Status Report as of 08/04/2004 ------------------ A1

Attachment 2: Drawings for Specimen Machining ------------------------- B1

Attachment 3: Materials Characterization Data Forms -------------------------C1

Attachment 4: List of ORNL Silicon Carbide Specimens-------------------- D1

Attachment 5: List of ORNL Molybdenum Specimens ---------------------E1

Attachment 6: Photographs of ORNL Specimens -----------------------------F1 


\section{TABLES}

Table 1. ORNL specimen quantity for materials listed in

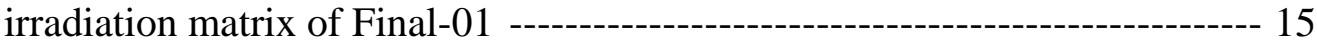

Table 2. Matrix plan for SiC/SiC composites provided by ORNL ----a--a---a----- 16

Table 3. Details of ORNL SiC and SiC/SiC materials------------------------------------- 16

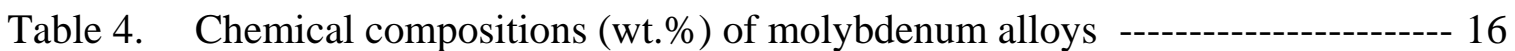

\section{ACRONYMS}




$\begin{array}{ll}\text { ASTM } & \text { American Society for Testing and Materials } \\ \text { BB } & \text { bend bar } \\ \text { CEA } & \text { Commissariat à l'Energie Atomique, France } \\ \text { CVD } & \text { chemical vapor deposition } \\ \text { CVI } & \text { chemical vapor infiltration } \\ \text { CYL } & \text { cylindrical sample } \\ \text { DOE } & \text { The Department of Energy } \\ \text { GFR } & \text { gas-cooled fast reactor } \\ \text { HNLS } & \text { Hi-Nicalon TM Type-S } \\ \text { ID } & \text { identification number } \\ \text { INL } & \text { Idaho National Laboratory } \\ \text { LCAC Mo } & \text { Low Carbon Arc Cast Molybdenum } \\ \text { LPS } & \text { Liquid-phase sintering } \\ \text { NITE } & \text { Nano-Infiltration and Transient Eutectic-Phase Process } \\ \text { ORNL } & \text { Oak Ridge National Laboratory } \\ \text { PIE } & \text { post-irradiation examination } \\ \text { PNNL } & \text { Pacific Northwest National Laboratory } \\ \text { PyC } & \text { pyrolytic carbon } \\ \text { R\&D } & \text { research and development } \\ \text { R\&H } & \text { Rohm \& Haas Advanced Materials } \\ \text { SiC/SiC } & \text { SiC-fiber-reinforced SiC-matrix ceramic composite } \\ \text { TDD } & \text { thermal diffusivity disk } \\ \text { TEM } & \text { transmission electron microscopy } \\ \text { Tpi } & \text { tows per inch } \\ \text { TySA } & \text { Tyranno }{ }^{\text {TM-SA }} \\ \text { UBE } & \text { Ube Industries, Ltd. } \\ & \end{array}$




\section{Acknowledgments}

The authors are grateful to William Corwin and Steve Zinkle at Oak Ridge National Laboratory for programmatic direction, to Mary Williams for arrangement of machining, to Mitchell Meyer and Jian Gan at Idaho National Laboratory for coordination with French collaborators, and to Akira Kohyama and Tatsuya Hinoki for arrangement of NITE and LPS materials.

This work is sponsored by the U.S. Department of Energy, Office of Nuclear Energy Science and Technology under contract DE-AC05-00OR22725 with Oak Ridge National Laboratory, managed by UT-Battelle, LLC. 


\section{Executive Summary}

The FUTURIX-MI is a international collaboration program between U.S. Department of Energy (DOE) and French Commissariat à l'Energie Atomique (CEA) for materials irradiation in Phenix fast reactor in France in support of gas fast reactor (GFR) materials and fuel R\&D effort. ORNL Generation IV Materials Program provides selected silicon carbide ceramics $(\mathrm{SiC})$ and composites $(\mathrm{SiC} / \mathrm{SiC})$ and molybdenum alloys for the evaluation of effect of neutron irradiation in a GFR-relevant condition. Projected irradiation condition in this program is to a fast neutron fluence of $\sim 1 \times 10^{27} \mathrm{n} / \mathrm{m}^{2}$ $\left(\mathrm{E}>0.1 \mathrm{MeV}\right.$ ) at a temperature of $\sim 1000^{\circ} \mathrm{C}$. The irradiation is scheduled to start in early 2007 and continue for 2 operation cycles of the Phenix reactor. This report compiles the details of specimen matrix, materials, and post-irradiation examination (PIE) plans for the part of contribution from ORNL. Also, a potential R\&D item which is recommended as a preparatory work for PIE is identified. 


\section{Overview}

This document describes technical details, primarily regarding the planning of matrix and fabrication and characteristics of the materials, of the ORNL contribution to a U.S. Department of Energy (DOE) - Franch Commissariat à l'Energie Atomique (CEA) collaborative FUTURIX-MI program for materials irradiation in Phenix fast reactor in France in support of gas fast reactor (GFR) materials and fuels R\&D effort. ORNL Generation IV Materials Program provides selected silicon carbide (SiC) ceramics and composites and molybdenum alloys for evaluation of the effect of neutron irradiation in a GFR-relevant condition. Projected irradiation condition in this program is to a fast neutron fluence of $\sim 1 \times 10^{27} \mathrm{n} / \mathrm{m}^{2}(\mathrm{E}>0.1 \mathrm{MeV})$ at a temperature of $\sim 1000^{\circ} \mathrm{C}$. The irradiation is scheduled to start in early 2007 and continue for 2 operation cycles of the Phenix reactor.

Document ('FUTURIX-MI Status Aug-04.doc') containing general information of the FUTURIX-MI experiment is appended as Attachment 1. Note that the specimen matrix plan in Attachment 1 has been outdated.

\section{Key Schedule}

The schedule revised in March, 2005, is as below.

Delivery of ORNL specimen to INL

Delivery of US specimens to CEA

Capsule fabrication

Start of irradiation
May 2, 2005

May 31, 2005

June 2005

Early 2007

Post-irradiation examination (PIE) follows as soon as the irradiated samples are transferred to ORNL and made available for testing, in year 2008 or later. 


\section{ORNL Specimen Matrix}

ORNL specimen matrix plan is shown in Table 1. The matrix plan is in accordance with the Futurix-MI entire matrix plan Version Final-01, as of 03/08/05, found in Microsoft Excel worksheet entitled 'FUTURIX-MI composition 2005-03-08.xls,' prepared by Dr. Jian Gan at INL.

Table 1 - ORNL specimen quantity for materials listed in irradiation matrix of Final-

\begin{tabular}{|c|c|c|c|c|c|c|c|c|c|c|c|c|}
\hline \multirow{3}{*}{$\begin{array}{l}\text { Material, Manufacturer } \\
\text { (Supplier) }\end{array}$} & & \multirow{2}{*}{\multicolumn{3}{|c|}{ Beam $25 \times 2 \times 1.5$}} \\
\hline & \multicolumn{3}{|c|}{ Disc $8 \mathrm{~d} \times 2 \mathrm{~h}$} & \multicolumn{3}{|c|}{ TEM 3dx0.15t } & \multicolumn{3}{|c|}{ Cylinder 3dx10h } & & & \\
\hline & Irrad & Ctrl & Total & Irrad & Ctrl & Total & Irrad & Ctrl & Total & Irrad & Ctrl & Total \\
\hline $\begin{array}{c}\text { SiC/SiC NITE, UBE } \\
\text { (ORNL) }\end{array}$ & 10 & 10 & 20 & 20 & 10 & 30 & 1 & 1 & 2 & 6 & 6 & 12 \\
\hline $\mathrm{SiC} / \mathrm{SiC} \mathrm{CVI}$, ORNL & 10 & 10 & 20 & 20 & 10 & 30 & 1 & 1 & 2 & 12 & 12 & 24 \\
\hline LCAC Mo Alloy, ORNL & 5 & 5 & 10 & 20 & 10 & 30 & 1 & 1 & 2 & 6 & 6 & 12 \\
\hline MoZrB, ORNL & 5 & 5 & 10 & 20 & 10 & 30 & & & & 6 & 6 & 12 \\
\hline
\end{tabular}

\subsection{Silicon Carbide Ceramics and Composites}

\section{(1) Matrix Details}

The detailed matrix plan for $\mathrm{SiC} / \mathrm{SiC}$ composites and monolithic SiC to be provided by or through ORNL is listed in Table 2. Descriptions of individual materials are given in Table 3. All the composite materials consist of near-stoichiometric SiC fibers and matrices and therefore the neutron tolerance greatly improved over the conventional $\mathrm{SiC} / \mathrm{SiC}$ composites is expected [1-4]. The CVI composites are the reference SiC/SiC

Table 2 - Matrix plan for SiC/SiC composites provided by ORNL.

File: FUTURIX-MI_US_SiC_Matrix_050314 Sheet: Matrix Summary

Numbers of ORNL Silicon Carbide Specimens for FUTURIX-MI Experiment

\begin{tabular}{|c|c|c|c|c|c|c|c|c|c|c|c|c|c|c|c|c|c|}
\hline \multirow{3}{*}{ Category } & \multirow{3}{*}{ Material } & \multirow{3}{*}{ Mater ID } & \multicolumn{5}{|c|}{ For Irradiation } & \multicolumn{5}{|c|}{ Control } & \multicolumn{5}{|c|}{ Total } \\
\hline & & & BB & TDD & $\mathrm{CYL}$ & TEM1 & TEM2 & BB & TDD & CYL & TEM1 & TEM2 & BB & TDD & $\mathrm{CYL}$ & TEM1 & TEM2 \\
\hline & & & 54 & 60 & 6 & 84 & 16 & 54 & 60 & 6 & & 4 & 108 & 120 & 12 & 84 & 20 \\
\hline \multirow{6}{*}{ NITE } & TySA-NITE & 18 & 6 & 3 & 1 & & & 6 & 3 & 1 & & & 12 & 6 & 2 & & \\
\hline & LPS-SiC & 4 & & 3 & & 10 & & & 3 & & 10 & & & 6 & & 20 & \\
\hline & CVD-SiC R\&H & 1 & & 2 & & & & & 2 & & & & & 4 & & & \\
\hline & Hybrid-CVI & 17 & & 2 & & & & & 2 & & & & & 4 & & & \\
\hline & Subtotal & & 6 & 10 & 1 & \begin{tabular}{l|l}
10 \\
\end{tabular} & & 6 & 10 & 1 & 10 & & 12 & 20 & 2 & 20 & \\
\hline & Assignment & & 6 & 10 & 1 & \multicolumn{2}{|c|}{20} & 6 & 10 & 1 & \multicolumn{2}{|c|}{10} & 12 & 20 & 2 & \multicolumn{2}{|c|}{30} \\
\hline \multirow{9}{*}{$\mathrm{CVI}$} & TySA-CVI-Ref & 11 & & 2 & & & & & 2 & & & & & 4 & & & \\
\hline & TySA-CVI-TI & 12 & & 2 & & & & & 2 & & & & & 4 & & & \\
\hline & TySA-CVI-TF & 13 & & 2 & & & & & 2 & & & & & 4 & & & \\
\hline & HNLS-CVI-Ref & 14 & 6 & 2 & & & & 6 & 2 & & & & 12 & 4 & & & \\
\hline & HNLS-CVI-TI & 15 & 6 & 2 & 1 & & & 6 & 2 & 1 & & & 12 & 4 & 2 & & \\
\hline & CVD-SiC R\&H & 1 & & & & 12 & & & & & 8 & & & & & 20 & \\
\hline & SC-SiC & 3 & & & & & 8 & & & & & 2 & & & & & 10 \\
\hline & Subtotal & & 12 & 10 & 1 & 12 & 8 & 12 & 10 & 1 & 8 & 2 & 24 & 20 & 2 & 20 & 10 \\
\hline & Assignment & & 12 & 10 & 1 & \multicolumn{2}{|c|}{20} & 12 & 10 & 1 & \multicolumn{2}{|c|}{10} & 24 & 20 & 2 & \multicolumn{2}{|c|}{30} \\
\hline
\end{tabular}


composites for nuclear applications [4,5], whereas the NITE composite is a new class of $\mathrm{SiC} / \mathrm{SiC}$ composite that potentially provides superior baseline properties and acceptable irradiation performance [5-11]. The monolithic SiC materials are either matrix materials for the composite materials or high-quality reference materials for studying the fundamental irradiation effects in SiC.

Table 3 - Details of ORNL SiC and SiC/SiC materials

\begin{tabular}{|c|c|c|c|}
\hline Material & Fiber Fabric & Interphase & Matrix \\
\hline CVD-SiC R\&H & Roam and Haas Advanced Materials, CVD-SiC, Standard Resistivity \\
Grade (lot \#9130)
\end{tabular}

\section{Bend bar specimens}

The specimen type BB in Table 2 represents bend bar with dimensions of 25mm (length) $\mathrm{x} 2.5 \mathrm{~mm}$ (width) x $2 \mathrm{~mm}$ (thickness). With this small specimen width, uni-directionally reinforced composites or 2-dimensional composites with thread count $>20$ tpi (tows-perinch) have to be selected. This is because the composite strength tends to deviate from the systematic specimen width dependence unless 2 or more fiber tows are accommodated in each fabric layer of the 2-dimensional composite [12]. Two Hi-Nicalon ${ }^{\mathrm{TM}}$ Type-S (HNLS) chemically vapor infiltrated (CVI) composites, which had been fabricated for this program, are 2D plain-weave fabric composites with 24 - 25 tpi tread counts instead of 16 tpi for other 2D SiC fiber composites in standard specifications. The Tyranno ${ }^{\mathrm{TM}}$ - 
SA (TySA) NITE composite is uni-directionally reinforced. The reference-interphase (with the '-Ref' suffix) is nominally 150nm-thick pyrocarbon (PyC) while the thininterphase ('-TI') is nominally 50nm-thick PyC. The effect of PyC interphase thickness on non-irradiated mechanical properties of $\mathrm{SiC} / \mathrm{SiC}$ composites in this class has been studied in detail $[13,14]$. A major microstructural modification and mechanical property degradation in carbon materials during neutron irradiation have been reported [15-18], however, the influence of such irradiation effects in thin interphases on macroscopic properties of $\mathrm{SiC} / \mathrm{SiC}$ composites has not been made clear. It is general speculation that the thinner PyC interphase composites are supposed to be more resistant to neutron damage. It is expected that the Futurix-MI experiment answers these questions.

\section{Thermal diffusivity specimens}

The specimen type TDD in Table 2 represents a type of thermal diffusivity disc. Specimens of CVD-SiC R\&H and Hybrid-CVI have been added to the NITE category, because the total of only 12 TDD specimens of NITE composites and matrix material (LPS-SiC) had been supplied by Kyoto University while 20 TDD specimens had been requested. CVD-SiC R\&H samples are also provided by PNNL and included in the European matrix. 2 duplicate specimens each for 5 different composites are assigned for irradiation in CVI category. This combined specimen matrix should provide sufficient comprehensive understanding of post-irradiation thermal conductivity in CVI and NITE $\mathrm{SiC} / \mathrm{SiC}$ composites and contributions from the composite constituents in the irradiation condition of Futurix-MI [19-22].

\section{TEM specimens}

The standard TEM specimen (with a round disc-shape) is designated type TEM1. Type TEM2 with a flat edge section was introduced for material identification. All the TEM specimens of CVD-SiC R\&H and LPS-SiC are of type TEM1, whereas all the SC-SiC specimens are of type TEM2.

\section{Specimen identification}

Individual ID's were not engraved onto the $\mathrm{SiC}$ and $\mathrm{SiC} / \mathrm{SiC}$ specimens. This is because ID's engraved on the textured surface of small composite specimens may not be readable, whereas the specimen-to-specimen variations in surface features (or 'fingerprint') should give sufficient information that enables the specimen identification by visual inspection. Also, the CVI and NITE composites are easily distinguishable from the difference in surface features. The surface features consist of the fabric texture and pore distributions unique to individual specimen. These features will not change during the reactor irradiation for a long term. A set of photographs of the machined samples is provided for future identification. 


\section{(2) PIE Plan}

Irradiated samples will be shipped to and tested at ORNL.

It is highly preferred to test the type BB specimens in tension instead of in flexure, although they have been designed for flexural test. The type BB specimens are most likely to fail in a mode of interlaminar shear if tested in flexure, because they will have a support span-to-depth ratio of $~ 10: 1$. The minimum span-to-depth ratios recommended in ASTM Standard C1341 are 16:1 and 32:1 in three-point and four-point-1/4 configurations, respectively, in order to avoid the interlaminar failure. The interlaminar shear fracture strength is correlated primarily with the matrix fracture toughness and features of the pore that happened to be a crack initiation site. On the other hand, the mechanical properties of fibrous composites are determined by various properties of fiber, interphase, and matrix. Therefore, if interlaminar shear is going to be the primary failure mode, the effect of irradiation on composite properties can not be evaluated. Since the type BB specimens are smaller than typical miniature tensile specimens for neutron irradiation studies, it is recommended that an appropriate and reliable testing technique is developed in FY2006 - 2007.

The type TDD specimens will be used for evaluation of thermal diffusivity at temperatures ranging from ambient to the irradiation temperature $\left(1000^{\circ} \mathrm{C}\right)$.

The TEM samples will be used for microstructural examination by transmission electron microscopy, hardness / modulus evaluation by nano-indentation, and fracture toughness evaluation by micro-indentation.

\subsection{ORNL Molybdenum Alloys}

\section{(1) Alloys and Specimens}

ORNL molybdenum alloys consist of a newly developed weldable molybdenum alloy (MoZrB) and a reference material (LCAC). The MoZrB material, named Alloy-6 in the alloy development program, was selected for irradiation because it showed most promising mechanical properties before irradiation among new alloys. Chemical compositions of the two alloys are given in Table 4. The hot-rolled coupons are heattreated in vacuum before machining specimens.

Table 4. Chemical compositions (wt.\%) of molybdenum alloys

\begin{tabular}{|l|l|l|l|l|l|l|l|l|l|}
\hline Mater & Mo & C & Zr & B & Fe & Ni & Al & O & Si \\
\hline MoZrB & Bal. & 0.0087 & 0.0028 & 0.0017 & & & 0.0006 & 0.0017 & \\
\hline LCAC & Bal. & 0.014 & & & 0.0031 & $<0.001$ & & 0.0006 & 0.0013 \\
\hline
\end{tabular}


As listed in Table 1, 20 disk specimens (8 mm dia.), 60 TEM specimens, 2 cylinders, and 24 small beam specimens were prepared for irradiation or as control specimens.

\section{(2) PIE Plan}

TEM specimens - After irradiation the TEM specimens will be used for two purposes: transmission electron microscopy (TEM) and measuring microhardness. Through the TEM work characteristics of small radiation-induced defects and large voids will be examined. The microhardness testing on the TEM specimens will supply irradiation hardening information for the alloys.

$8 \mathrm{~mm}$ Disks - The disks will be used for ball indentation tests to measure deformation properties and temperature dependencies. Ball indentation testing method using a small ball of $1 \mathrm{~mm}$ diameter or smaller has been established in ORNL and other places.

Beam specimens - The small beams will be deformed in three point bend jigs to obtain bending deformation properties. Some physical properties such as density and electrical resistivity will be measured. Alternatively, it will be tried to measure fracture mechanics parameters from those specimens if they can be notched.

The cylinder specimen - It is considered as backup material for any applications. 


\section{References}

[1] L. L. Snead, Y. Katoh, A. Kohyama, J. L. Bailey, N. L. Vaughn and R. A. Lowden, Journal of Nuclear Materials 283-287 (2000) 551-555.

[2] Y. Katoh, A. Kohyama, L.L. Snead, T. Hinoki and A. Hasegawa, "Neutron Tolerance of Advanced SiC-Fiber / CVI-SiC Composites,” Proceedings of the 19th IAEA Fusion Energy Conference, IAEA-CN-94 (International Atomic Energy Agency, 2002) FT/P1-03.

[3] T. Hinoki, L.L. Snead, Y. Katoh, A. Hasegawa, T. Nozawa and A. Kohyama, Journal of Nuclear Materials 307-311 (2002) 1157-1162.

[4] Y. Katoh, A. Kohyama, T. Hinoki and L.L. Snead, Fusion Science \& Technology 44 (2003) 155.

[5] R. Naslain, "Design, preparation and properties of non-oxide CMCs for application in engines and nuclear reactors: an overview,” Composites Science and Technology 64 (2004) 155-170.

[6] Y. Katoh, A. Kohyama, S.M. Dong, T. Hinoki and J-J. Kai, "Microstructure and Properties of Liquid Phase-Sintered SiC/SiC Composites,” Ceramic Engineering and Science Proceedings, Volume 23, Issue 3 (2002) 363-370.

[7] Y. Katoh, S.M. Dong and A. Kohyama, “A Novel Processing Technique of Silicon Carbide-Based Ceramic Composites for High Temperature Applications,” Ceramic Transactions, Vol.144 (2002) 77-86.

[8] Y. Katoh, S.M. Dong and A. Kohyama, “Thermo-Mechanical Properties and Microstructure of Silicon Carbide Composites Fabricated by Nano-Infiltrated Transient Eutectoid Process,” Fusion Engineering and Design 61-62 (2002) 723732.

[9] S.M. Dong, Y. Katoh, and A. Kohyama, "Preparation of SiC/SiC Composites by Hot Pressing, Using Tyranno-SA Fiber as Reinforcement," Journal of the American Ceramic Society, Vol. 86, No. 5 (2003) 26-32.

[10] T. Hino, T. Jinushi, Y. Hirohata, M. Hashiba, Y. Yamauchi, Y. Katoh and A. Kohyama, "Helium Gas Permeability of SiC/SiC Composite Developed for Blanket Component,” Fusion Science and Technology, Volume 43 (2003) 184-190.

[11] Y. Katoh, A. Kohyama, T.Nozawa, M. Sato, "SiC/SiC Composites through Transient Eutectic-phase Route for Fusion Applications,” Journal of Nuclear Materials, Volumes 329-333 (2004) 587-591.

[12] T. Nozawa, T. Hinoki, Y. Katoh, A. Kohyama and E. Lara-Cruzio, Small Specimens Test Techniques: Fourth Volume (ASTM STP 1418, M.A. Sokolov, J.D. Landes and G.E. Lucas, Eds., ASTM International, West Conshohocken, PA, 2002) 294-305.

[13] Y. Katoh , T. Nozawa, L.L. Snead, T. Hinoki, A. Kohyama, N. Igawa, T. Taguchi, Materials Transactions, 46 (2005) 527-535. 
[14] Y. Katoh , T. Nozawa, and L.L. Snead, "Mechanical Properties of Thin PyC Interphase SiC-Matrix Composites Reinforced with Near-Stoichiometric SiC Fibers,” Journal of the American Ceramic Society, in printing.

[15] B.T. Kelly, Physics of Graphite, Applied Science Publishers, London (1981).

[16] G.B. Engle and W.P. Etherly, Irradiation behavior of graphite at high temperature, High Temperatures - High Pressures 4 (1972) 119-158.

[17] R.J. Price, "High temperature neutron irradiation of highly oriented carbons and graphites," Carbon 12 (1974) 159-169.

[18] B.T. Kelly and T.D. Burchell, "Structure-related property changes in polycrystalline graphite under neutron irradiation," Carbon 32 (1994) 499-505.

[19] L.L. Snead, S.J. Zinkle, and D.P. White, "Thermal conductivity degradation of ceramic materials due to low temperature, low dose neutron irradiation,” Journal of Nuclear Materials 340 (2005) 187-202.

[20] T. Nozawa, Y. Katoh, and L.L. Snead, "Tensile and thermal properties of chemically vapor-infiltrated silicon carbide composites with various high-modulus fiber reinforcements,” Ceramic Engineering and Science Proceedings, Vol. 26 (2005).

[21] T. Nozawa, Y. Katoh, L.L. Snead, T. Hinoki, and A. Kohyama, "Characterization of chemically vapor infiltrated silicon carbide composites reinforced by various high modulus fibers: I. Thermal conductivity,” Fusion Materials Semiannual Report, DOE/ER-0313/37 (2005) 11-16.

[22] Y. Katoh, T. Nozawa, L.L. Snead, T. Hinoki, and A. Kohyama, "Property tailorability for advanced CVI silicon carbide composites for fusion," submitted to Fusion Engineering and Design. 


\section{Attachment 1}

Futurix-MI Status Report as of 08/04/2004

(from Mitchell Meyer, August 2004) 


\subsection{Background}

The Gas-cooled Fast Reactor (GFR) is an attractive candidate for future deployment as a fourth generation nuclear power system. Both the U.S.D.O.E. and the French CEA have interest in studying the technical feasibility of the GFR. Joint work in the fuels area began in FY02 as an effort funded at a small level under the I-NERI project 'Development of Gen IV Advanced GasCooled Reactors with Hardened/Fast Neutron Spectrum' by defining fuel requirements, proposing fuel concepts to meet these requirements, and modeling the in-reactor behavior of these concepts. During this work, it became clear almost immediately that very few materials were available that both met GFR neutronic requirements and could withstand postulated core loss-of-coolant accident conditions without melting or restructuring. These materials generally fall into the class of monocarbide and mononitride ceramic compounds.

There is very little materials property and irradiation data on these materials to support evaluation of their use as GFR fuel materials. U.S. efforts to obtain this data include ion irradiation studies and the GFR-F1 irradiation in the ATR (Advanced Test Reactor); however this irradiation is limited to low dose due to the low fast flux in the thermal spectrum ATR. Both DOE and CEA agreed from early on in the I-NERI program that fast spectrum testing to damage levels representative of GFR fuel was required in order to complete a representative assessment of the potential of these materials for service as GFR fuel matrix and cladding materials.

Three coordination meetings were held between U.S. and CEA technical staff during this fiscal year. The first meeting was an informal discussion held in conjunction with the GLOBAL 2003 meeting in New Orleans (November 2003). Here general discussion focused on the structure of the project and the potential for U.S. collaboration and partial funding of FUTURIX-MI. The second meeting was held at ANL-E in Chicago in February of 2004 in conjunction with the CEA/DOE coordination meeting. This second meeting focused on further details of U.S. participation in FUTURIX-MI and details related to the financing of the experiment. The third meeting was held in August at CEA Cadarache in conjunction with the FUTURIX-FTA coordination meeting to finalize experiment plans and to delegate responsibilities for sample preparation.

This report updates the status of this potential collaborative experiment and highlights progress made during FY-2004.

\subsection{Objectives of FUTURIX-MI}

GFR performance goals require fuels with high heavy metal density, high thermal conductivity, low irradiation induced swelling, melting temperatures exceeding $2000^{\circ} \mathrm{C}$, and low parasitic neutron absorption. Based on GFR reference core design, two types of fuel have been identified that are most likely to meet GFR goals. These are refractory clad pin-type fuels and refractory matrix dispersion fuels.

Based on postulated GFR behavior during normal and accident conditions, a set of general criteria for fuel matrix and cladding materials has been derived. Based on these criteria, the class of high-temperature moncarbides and mononitrides appear most likely to meet GFR goals as fuel 
matrix materials; specifically $\mathrm{SiC}, \mathrm{TiC}, \mathrm{ZrC}, \mathrm{TiN}$, and $\mathrm{ZrN}$ have been identified. Pin-type cladding materials include $\mathrm{SiC}$ composites and Nb-based refractory alloys. The response of these GFR candidate fuel materials to fast neutron damage levels in the range required for GFR operation at high temperatures is not known. Assessment of fuel feasibility requires determination of basic fuel and material properties through irradiation testing and assessment.

The FUTURIX-MI irradiation is devoted to the behavior of inert matrix materials under GFR conditions with temperatures of $\sim 1000^{\circ} \mathrm{C}$ and fast neutron fluence on the order of $1.0 \times 10^{27} \mathrm{n} . \mathrm{m}^{-2}$ $(\mathrm{E}>0.1 \mathrm{MeV})$. Specimens of candidate fuel matrix and cladding materials will be irradiated in a special device in Phénix in order to provide specimens for postirradiation characterization. Postirradiation examination will focus on the measurement of thermal properties, mechanical properties, and microstructural analysis of the irradiated materials.

Where possible, non-fuel related high-temperature structural materials were considered for irradiation in the FUTURIX-MI experiment.

Postirradiation examination responsibilities will be shared between CEA and DOE. CEA estimates the total cost of this experiment to be 4.270 M€. DOE and the National Technical director for AFCI fuels have tentatively agreed to fund this experiment at $1.25 \mathrm{M} €$, to provide specimens of mutual interest to both parties, and to share in the duties of postirradiation examination and reporting.

\subsection{Overview of the FUTURIX-MI Experiment}

The configuration of the FUTURIX-MI experiment is shown in Fig. 1. Material test specimens are mounted in a specially designed $\mathrm{SiC}$ sample holder. The sample holder is in turn encapsulated in a metal alloy heating capsule and a stainless steel outer can. The cans are stacked inside of a standard Phénix KMI irradiation capsule.

Table 1 and Fig. 2 provide details on general sample types and specific geometry. Specimens are provided for measurement of thermal expansion, thermal diffusivity, mechanical property testing, density, electrical resistivity, and examination by transmission microscopy. In order to provide for the as-designed heating rates, all specimen cavities are to be filled with specimens.

In addition to the materials test specimens, two types of temperature monitors are included in the SiC sample holders. These are SiC thermal expansion monitors, which are located near the edges of the sample holder and metal fuse temperature monitors located in the center of the SiC capsule. 
Table 1. Types of FUTURIX-MI specimens

\begin{tabular}{|c|l|l|}
\hline \multicolumn{1}{|c|}{ Sample } & \multicolumn{1}{|c|}{ Purpose } & \multicolumn{1}{c|}{ Dimensions } \\
\hline $8 \mathrm{~mm}$ disc & Thermal diffusivity measurement & 8 mm dia. $\times 2 \mathrm{~mm}$ thick \\
\hline $3 \mathrm{~mm}$ rod & $\begin{array}{l}\text { Thermal expansion, density, backup } \\
\text { TEM }\end{array}$ & $\begin{array}{l}3 \mathrm{~mm} \text { dia. } \times 5 \mathrm{~mm} \text { of } 10 \mathrm{~mm} \text { long, } \\
\text { electrical resistivity }\end{array}$ \\
\hline $3 \mathrm{~mm}$ disk & TEM specimens & $\begin{array}{l}3 \mathrm{~mm} \text { dia. } \times 0.15 \mathrm{~mm} \text { thick, small } \\
\text { punch test }\end{array}$ \\
\hline Bend bars & Mechanical testing & $2.0 \times 2.5 \times 25 \mathrm{~mm}$ \\
\hline
\end{tabular}

The experiment matrix as of August 2004 is shown in Table 2. The experiment stackup consists of 8 cans. Two types of mutually compatible specimens can be placed in each can, as indicated in the table. Provision of specimens is divided roughly equally between CEA and DOE.

Table 2. FUTURIX-MI experiment matrix as of August 2004

\section{(Table 2 needed update; deleted by Katoh)}

The eight cans are loaded in a Phénix KMI capsule. The KMI capsule will be located near the center of the Phénix core for irradiation, as shown in Fig. 3, where it will reside for two cycles totaling 240 effective full power days for a goal fast neutron fluence $(E>100 \mathrm{KeV})$ of $8 \times 10^{26}$ $\mathrm{n} / \mathrm{m}^{2}$.

CEA has requested that a backup matrix be formulated in case samples listed in Table 2 cannot be provided by June of 2004. Note that some of the materials in the current matrix are 'placeholders' that are commercially available materials offered where CEA was not able to provide novel materials as originally intended. The Cercom TiN in capsule 6 and the Cercom $\mathrm{ZrC}$ in capsule 7 fall into this category. Additional Mo alloys can be added as TEM and small beam specimens as indicated in capsule 8 . Nb-Zr alloys could be consolidated into one-half of capsule 2 if appropriate PWC-11 specimens can't be fabricated, leaving space for multiple samples, preferably metallic. The backup matrix should be defined by the end of September 2004.

\subsection{Current Status}

I-NERI agreements were written during the second quarter of FY04 and are currently in place with ITU and CEA for GFR fuel development. Collaboration under the new I-NERI agreements is scheduled to begin with the start of the 2005 fiscal year. The I-NERI agreement with CEA includes tasks associated with the FUTURIX-MI experiment.

An 'implementation agreement' based on the FUTURIX-FTA model has been drafted and is awaiting action by DOE.

During the February meeting, the possibility of the addition of 8 additional capsules containing materials of general interest to Gen IV was discussed. Our understanding was that CEA agreed to this in principal, but insisted that DOE shoulder all of the costs associated with these additional capsules and provide a definite list of materials by April. CEA did not provide a cost estimate, however, despite repeated inquiries in February through May. ANL provided repeated expressions of interest during this time frame, and a list of additional specimens for the eight 
capsules was provided to CEA in April of 2004. During a DOE/CEA GFR INERI meeting in Idaho Falls in May of 2004, the CEA lead for GFR fuel development, including FUTURIX-MI, referred inquiries about the status of the additional capsules to CEA management. Attempts were made to arrange a face-to-face meeting between the AFCI Fuels NTD and the CEA manager in June, but a meeting did not occur due to scheduling conflicts. During the August FUTURIX coordination meeting, CEA was not willing to add additional capsules to the FUTURIX-MI experiment, stating that it was too late in the planning; the technical report having been completed in May without provision for the additional capsules.

\subsection{Schedule and deliverables}

Both the Presentation Report, which formally proposes the irradiation test to the Phénix reactor, and the Technical Report, which provides detailed calculations of the irradiation performance of the experiment have been completed by CEA and submitted to Phénix for review in May. Final technical specifications for the experiment will be based on this review, and specimen specifications will be sent to ANL for dissemination to affected parties.

The schedule for major U.S. milestones and/or deliverables associated with the FUTURIX-FTA fuels collaboration is shown in Table 3.

Data required for specimen characterization reports supplied with specimens are listed in Table 4.

Table 3. Schedule outline, milestones and deliverables related to FUTURIX-MI.

(Table 3 needed update; deleted by Katoh) 
Table 4. Characterization data for FUTURIX-MI specimens.

\begin{tabular}{|c|c|}
\hline Characteristic & Example \\
\hline $\begin{array}{l}\text { Fabrication method, and } \\
\text { method of } \\
\text { repeatability }\end{array}$ & $\begin{array}{l}\text { Fabrication procedures if not proprietary, method s of } \\
\text { ensuring sample-to-sample uniformity }\end{array}$ \\
\hline $\begin{array}{l}\text { Composition and impurity } \\
\text { content (required) }\end{array}$ & $\begin{array}{l}\text { Fe, Ni, Co, Cl, F, O, C, N, Hf (Hf for Zr-based } \\
\text { materials) }\end{array}$ \\
\hline $\begin{array}{l}\text { Composition and impurity } \\
\text { content (if possible) }\end{array}$ & $\mathrm{Cu}, \mathrm{Zn}, \mathrm{Mo}, \mathrm{Mn}, \mathrm{Cd}, \mathrm{S}$ \\
\hline Metallography & $\begin{array}{l}\text { Grain size, pore fraction and morphology, micro- } \\
\text { chemical analysis of inclusions }\end{array}$ \\
\hline Crystal structure & XRD, TEM if practical \\
\hline Stoichiometry & If possible \\
\hline Details of fiber reinforcement & Type, size, heat treatment \\
\hline Geometry & Sample dimensions, cracks, chips, discoloration, etc. \\
\hline $\begin{array}{lll}\text { Dimensional stability to } \\
1200^{\circ} \mathrm{C}\end{array}$ & If possible \\
\hline Physical properties & $\begin{array}{l}\text { Measurement of properties on the same batch of } \\
\text { materials (if practical on the actual FUTURIX-MI } \\
\text { specimens) before mid-2005: } \\
\text { Thermal conductivity: } \\
\text { Thermal diffusivity } \\
\text { Thermal expansion } \\
\text { Heat capacity } \\
\text { Others if possible: } \\
\text { Hemispherical total emittance } \\
\text { Shear modulus, eleastic modulus } \\
\text { Poisson's ratio } \\
\text { Fracture toughness } \\
\text { Tensile yield stress } \\
\text { Thermal creep }\end{array}$ \\
\hline Chemical compatibility & With respect to $\mathrm{SiC}$ and $\mathrm{Na}$ \\
\hline
\end{tabular}


Figure 1. FUTURIX-MI SiC sample holder and assembly

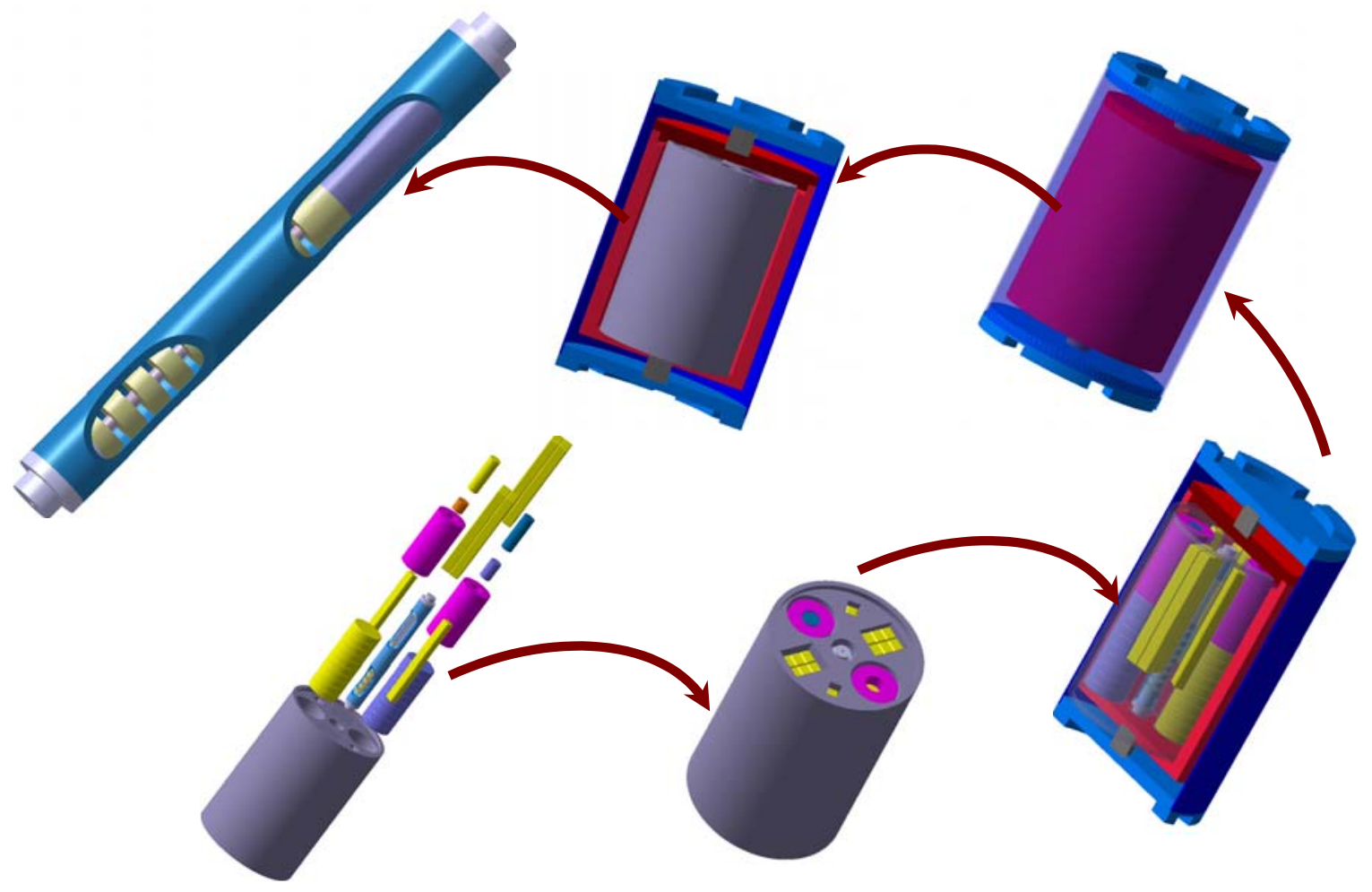



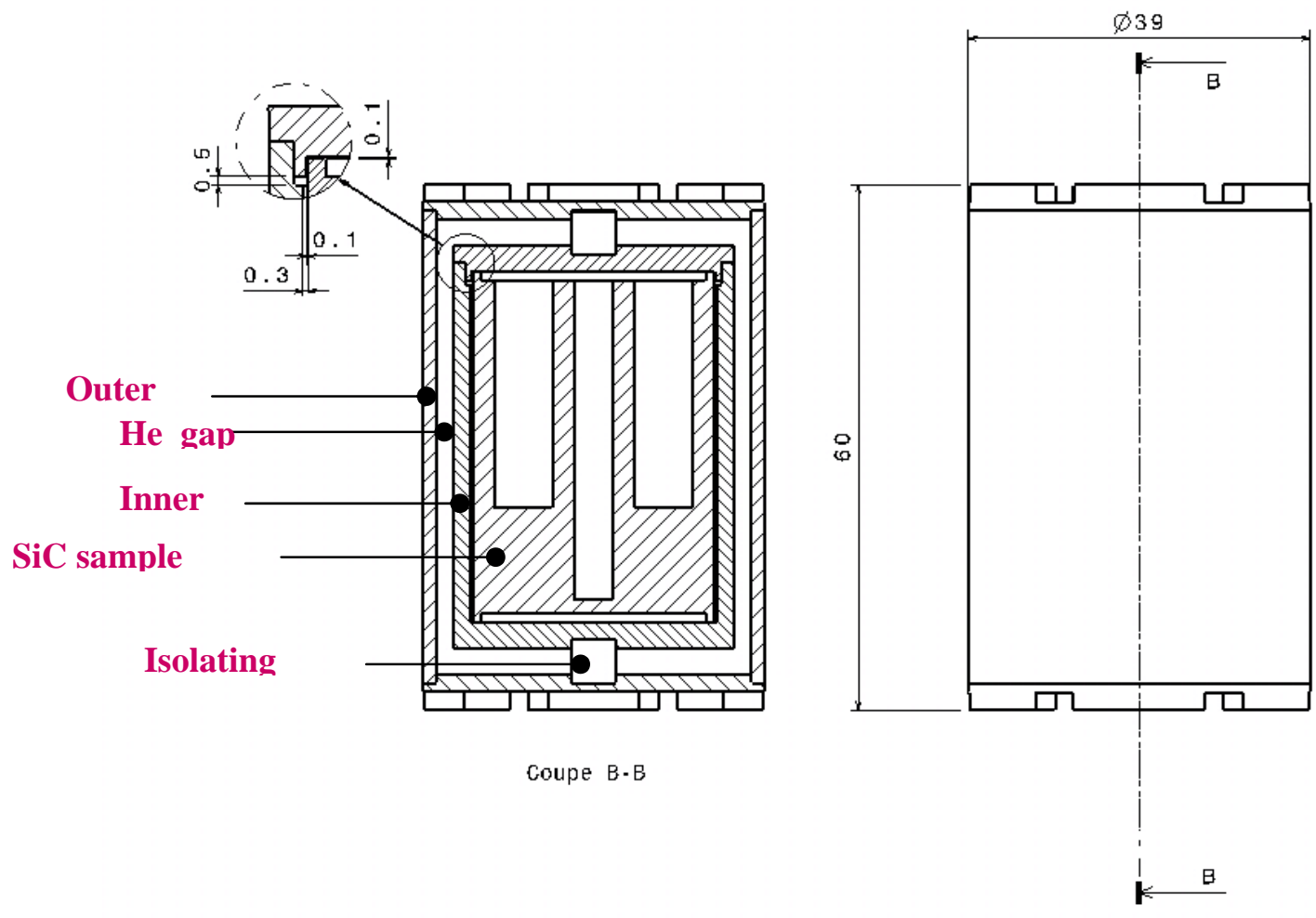
Figure 2. FUTURIX-MI sample dimensions
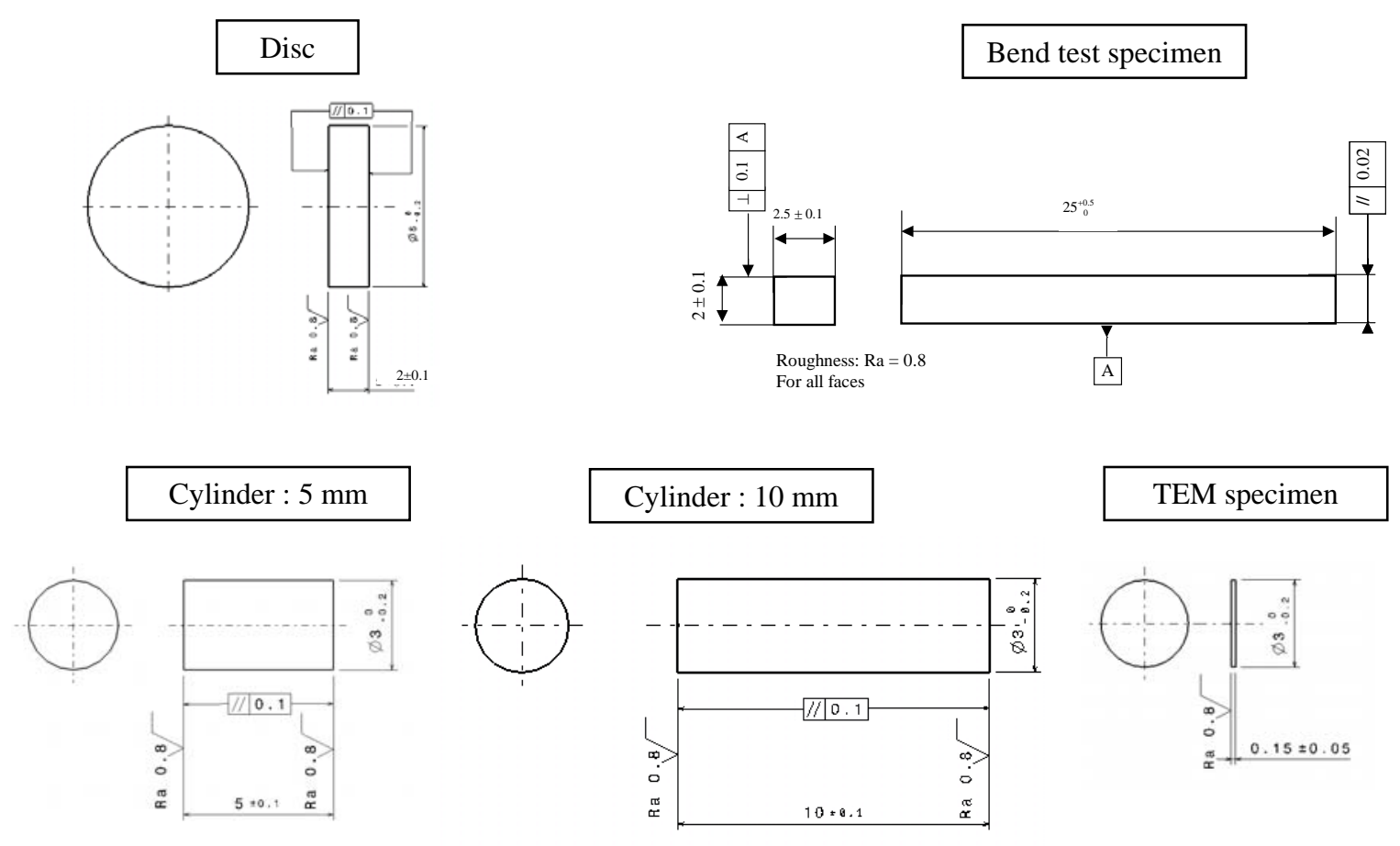

TEM specimen

Figure 3. FUTURIX-MI location in Phénix core (tentative).

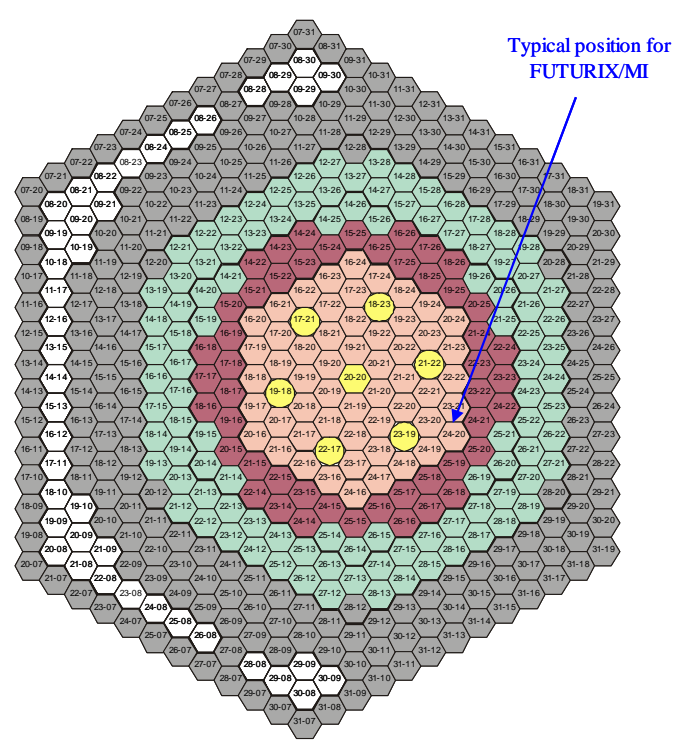




\section{Attachment 2}

Drawings for Specimen Machining 

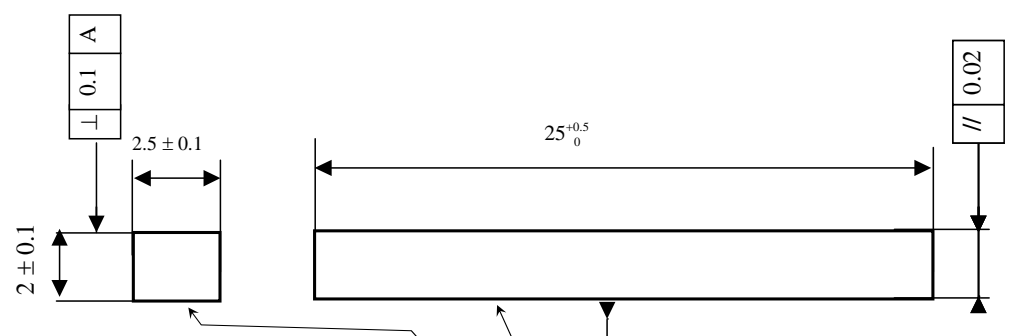

Roughness: $\mathrm{Ra}=0.8$

For all faces

\section{NOTE:}

1. Dimensions are in millimeter.

A

2. Limited surface smoothness due to material porosity is allowed.

3. The $2.5 \mathrm{~mm}$-wide faces are parallel to the fabric plane, i.e., the thickness $(2 \mathrm{~mm})$ along the fabric stacking direction.

4. Follow general guideline in ASTM Standard C1161-02c Section 7.2.4

5. All grinding in parallel to the longitudinal direction.
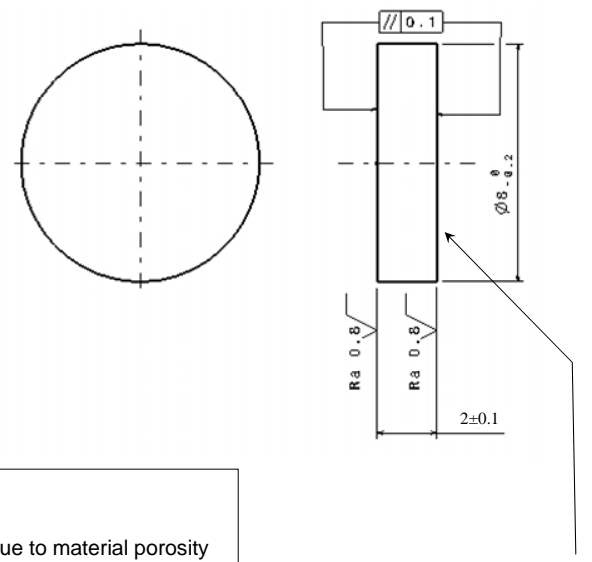

1. Dimensions are in millimeter.

2. Limited surface smoothness due to material porosity is allowed.

3. The round faces are parallel to the fabric plane, i.e., the thickness $(2 \mathrm{~mm})$ along the fabric stacking direction. 

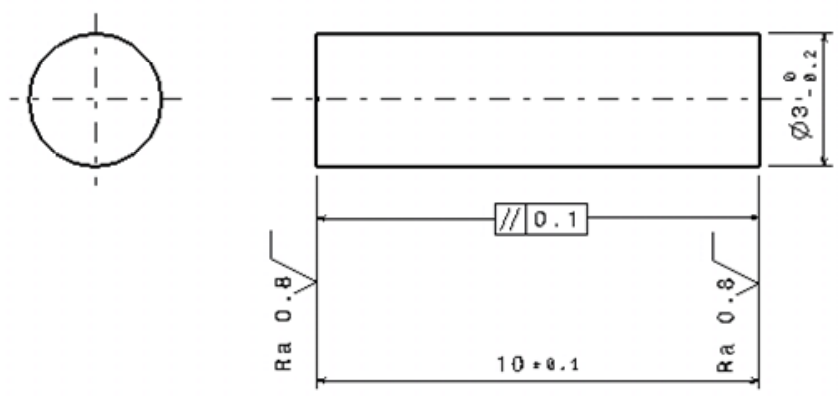

NOTE:

1. Dimensions are in millimeter.

2. Limited surface smoothness due to material porosity is allowed.

3. The longitudinal direction is parallel to the fabric plane.
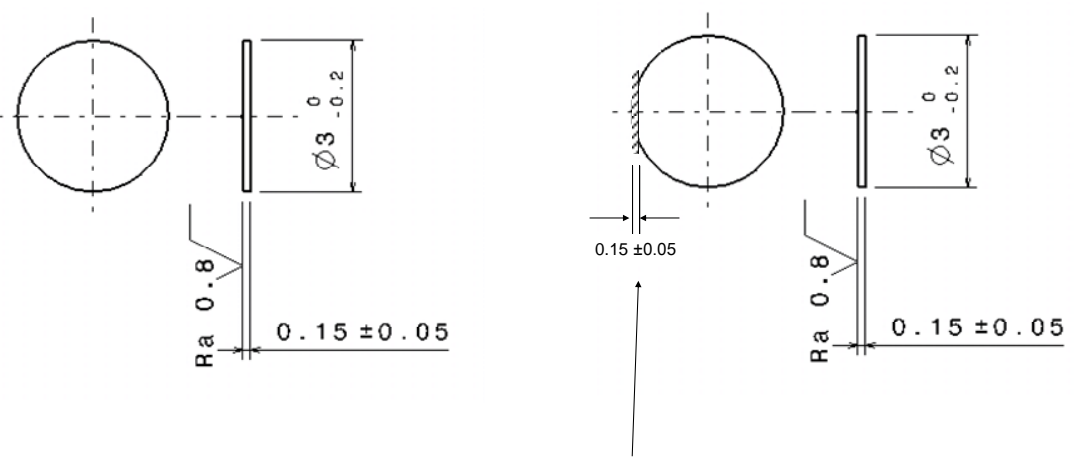

Remove $0.15 \mathrm{~mm}$ from the edge for material identification 


\section{Attachment 3}

Materials Characterization Data Forms 


\section{Characterization Data for Futurix-MI Experiment}

\begin{tabular}{|c|c|}
\hline Material & ORNL LCAC (Low Carbon Arc Cast) Molybdenum \\
\hline $\begin{array}{l}\text { Fabrication method, and } \\
\text { method of controlling } \\
\text { repeatability }\end{array}$ & $\begin{array}{ll}\text { - } & \text { Vacuum arc-cast, vacuum arc-remelting, extrusion, and rolling } \\
\text { - } & \text { Specimens were machined in as-stress relieved condition }\end{array}$ \\
\hline $\begin{array}{l}\text { Composition and impurity } \\
\text { content }\end{array}$ & $\begin{array}{l}0.014 \text { at- } \% \text { C, } 0.0031 \% \text { Fe, }<0.001 \% \text { Ni, } 0.0006 \% \text { O, } 0.0013 \% \text { Si, balance } \\
\text { Mo. }\end{array}$ \\
\hline Metallography & $\begin{array}{ll}\text { - } & \text { Elongated, fine grain microstructure } \\
\text { - } & \text { No second phase inclusion / precipitation has been found } \\
\end{array}$ \\
\hline Crystal structure & Body-centered cubic \\
\hline Stoichiometry & Not applicable \\
\hline $\begin{array}{l}\text { Details of fiber } \\
\text { reinforcement }\end{array}$ & Not applicable \\
\hline Geometry & $\begin{array}{l}\text { - Dimensions and mass of individual specimens are listed in a separate } \\
\text { table. } \\
\text { - } \quad \text { Appearance of specimens is found in a separate set of photographs. }\end{array}$ \\
\hline $\begin{array}{l}\text { Dimensional stability to } \\
1200^{\circ} \mathrm{C}\end{array}$ & - $\quad$ No experimental data with regard to irradiated dimensional stability \\
\hline Physical properties & $\begin{array}{ll}\text { - } & \text { Mass density of } 10.2 \mathrm{~g} / \mathrm{cm}^{3}(>99 \% \text { theoretical density) } \\
\text { - } & \left.\text { Thermal conductivity: } 138 \mathrm{~W} / \mathrm{m}-\mathrm{K} \text { (at } 20^{\circ} \mathrm{C}\right) \\
\text { - } & \text { Thermal diffusivity: } 5.4 \times 10^{-5} \mathrm{~m}^{2} / \mathrm{s}\left(\text { at } 20^{\circ} \mathrm{C}\right) \\
\text { - } & \text { Thermal expansion: } 5.1 \times 10^{-6} \mathrm{~K}^{-1}\left(20-1000^{\circ} \mathrm{C}\right) \\
\text { - } & \left.\text { Specific heat: } 250 \mathrm{~J} / \mathrm{kg}-\mathrm{K} \text { (at } 20^{\circ} \mathrm{C}\right) \\
\text { - } & \text { Tensile yield stress: } 796 \mathrm{MPa}\left(\text { at } 20^{\circ} \mathrm{C}, \mathrm{L} \text {-direction) }\right.\end{array}$ \\
\hline Chemical compatibility & $\begin{array}{ll} & \text { Limited reactivity with } \mathrm{SiC} \text { at }>\sim 850^{\circ} \mathrm{C} \\
\text { - } & \end{array}$ \\
\hline
\end{tabular}




\section{Characterization Data for Futurix-MI Experiment}

\begin{tabular}{|c|c|}
\hline Material & ORNL MoZrB Alloy \\
\hline $\begin{array}{l}\text { Fabrication method, and } \\
\text { method of controlling } \\
\text { repeatability }\end{array}$ & $\begin{array}{l}\text { - } \quad \text { Vacuum arc-cast, vacuum arc-remelting, extrusion, and rolling } \\
\text { - } \quad \text { Specimens were machined in as-stress relieved condition }\end{array}$ \\
\hline $\begin{array}{l}\text { Composition and impurity } \\
\text { content }\end{array}$ & $\begin{array}{l}0.0087 \text { at- } \% \text { C, } 0.0028 \% \text { Zr, } 0.0017 \% \text { B, } 0.0006 \% \text { Al, } 0.0017 \% \text { O, balance } \\
\text { Mo. }\end{array}$ \\
\hline Metallography & $\begin{array}{ll}\text { - } & \text { Elongated, fine grain microstructure } \\
\text { - } & \text { No second phase inclusion / precipitation has been found }\end{array}$ \\
\hline Crystal structure & Body-centered cubic \\
\hline Stoichiometry & Not applicable \\
\hline $\begin{array}{l}\text { Details of fiber } \\
\text { reinforcement }\end{array}$ & Not applicable \\
\hline Geometry & $\begin{array}{l}\text { - Dimensions and mass of individual specimens are listed in a separate } \\
\text { table. } \\
\text { - } \quad \text { Appearance of specimens is found in a separate set of photographs. }\end{array}$ \\
\hline $\begin{array}{l}\text { Dimensional stability to } \\
1200^{\circ} \mathrm{C}\end{array}$ & - $\quad$ No experimental data with regard to irradiated dimensional stability \\
\hline Physical properties & $\begin{array}{ll}\text { - } & \text { Mass density of } 10.2 \mathrm{~g} / \mathrm{cm}^{3}(>99 \% \text { theoretical density) } \\
\text { - } & \text { Thermal conductivity: } 138 \mathrm{~W} / \mathrm{m}-\mathrm{K}\left(\text { at } 20^{\circ} \mathrm{C}\right) \\
\text { - } & \text { Thermal diffusivity: } 5.4 \times 10^{-5} \mathrm{~m}^{2} / \mathrm{s}\left(\text { at } 20^{\circ} \mathrm{C}\right) \\
\text { - } & \text { Thermal expansion: } 5.1 \times 10^{-6} \mathrm{~K}^{-1}\left(20-1000^{\circ} \mathrm{C}\right) \\
\text { - } & \left.\text { Specific heat: } 250 \mathrm{~J} / \mathrm{kg}-\mathrm{K} \text { (at } 20^{\circ} \mathrm{C}\right) \\
\text { - } & \text { Tensile yield stress: } 803 \mathrm{MPa}\left(\text { at } 20^{\circ} \mathrm{C}, \text { L-direction) }\right.\end{array}$ \\
\hline Chemical compatibility & - $\quad$ Limited reactivity with $\mathrm{SiC}$ at $>\sim 850^{\circ} \mathrm{C}$ \\
\hline
\end{tabular}




\section{Characterization Data for Futurix-MI Experiment}

\begin{tabular}{|c|c|}
\hline Material & $\begin{array}{l}\text { ORNL CVI SiC/SiC Composites } \\
\text { (TySA-CVI-Ref / TI / TF) }\end{array}$ \\
\hline $\begin{array}{l}\text { Fabrication method, and } \\
\text { method of controlling } \\
\text { repeatability }\end{array}$ & $\begin{array}{l}\text { - } \quad \text { Reinforcement with Tyranno }{ }^{\mathrm{TM}} \text {-SA Grade-3 near-stoichiometric silicon } \\
\text { carbide fiber. } \\
\text { - } \quad \text { Interphase coating with pyrolytic carbon (50-150nm thickness) onto the } \\
\text { fiber surface prior to matrix infiltration. } \\
\text { - Deposition of stoichiometric silicon carbide matrix by isothermal / } \\
\text { isobaric chemical vapor infiltration. }\end{array}$ \\
\hline $\begin{array}{l}\text { Composition and impurity } \\
\text { content }\end{array}$ & $\begin{array}{l}0.2 \text { mass- } \% \text { Al, } 0.15 \% \text { O, } 0.05 \% \text { N, } 0.06 \% \text { Cl, } 3.3 \text { mass-ppm Fe, } 2.2 p p m ~ N i \\
\text { 28ppm Zr, } 0.5 p p m \text { Hf, } 5 \text { mass-ppb Co, } 5.8 \% \text { excess-C, balance SiC }\end{array}$ \\
\hline Metallographic feature & $\begin{array}{l}\text { - Porosity due to three types of matrix pores; bundle intersections (Type I), } \\
\text { fabric mesh (Type II), interlaminar (Type III) } \\
\text { - Inclusion / precipitation of phases other than SiC or carbon has been } \\
\text { found }\end{array}$ \\
\hline Crystal structure & Beta-SiC in fiber and matrix, glassy carbon in interphase \\
\hline Stoichiometry & $\begin{array}{ll}\text { - } & \text { The matrix is stoichiometric beta-SiC } \\
\text { - } & \text { The fiber consists primarily of beta-SiC } \\
\text { - } & \text { The fiber contains small amount }(\sim 5 \%) \text { of carbon that is present at multi- } \\
& \text { grain junctions of } \mathrm{SiC}\end{array}$ \\
\hline $\begin{array}{l}\text { Details of fiber } \\
\text { reinforcement }\end{array}$ & $\begin{array}{l}\text { - }\left[0 / 90^{\circ}\right] \text { lay-up of two-dimensional plain-weave fabric of Tyranno }{ }^{\mathrm{TM}}-\mathrm{SA} \\
\text { Grade-3 near-stoichiometric silicon carbide fiber produced by Ube } \\
\text { Industries, Ltd (Ube, Japan) } \\
\text { - } \quad \text { Fabric type / lot: PSA-S17F08PX / \#4000030981 }\end{array}$ \\
\hline Geometry & $\begin{array}{l}\text { - Dimensions and mass of individual specimens are listed in a separate } \\
\text { table. } \\
\text { - Appearance of specimens is found in a separate set of photographs. }\end{array}$ \\
\hline $\begin{array}{l}\text { Dimensional stability to } \\
1200^{\circ} \mathrm{C}\end{array}$ & $\begin{array}{l}\text { During neutron irradiation, these materials undergo lattice swelling, } \\
\text { which exhibits negative correlation with temperature and tends to } \\
\text { saturate by a neutron fluence of a few displacement-per-atom, in a way } \\
\text { very similar to monolithic crystalline silicon carbide. The expected } \\
\text { magnitude of saturated swelling at } 1000^{\circ} \mathrm{C} \text { is } \sim 0.5 \% \text { volumetric. }\end{array}$ \\
\hline Physical properties & $\begin{array}{ll}\text { - } & \text { Mass density of } 2.68 \mathrm{~g} / \mathrm{cm}^{3}(\sim 86 \% \text { theoretical density) } \\
\text { - } & \text { Thermal conductivity (in-plane): } 45 / 18 \mathrm{~W} / \mathrm{m}-\mathrm{K}\left(\text { at } 20 / 1000^{\circ} \mathrm{C}\right) \\
\text { - } & \text { Thermal conductivity (through-thickness): } 23 / 10 \mathrm{~W} / \mathrm{m}-\mathrm{K}\left(\text { at } 20 / 1000^{\circ} \mathrm{C}\right) \\
\text { - } & \text { Thermal expansion: } 4.5 \times 10^{-6} \mathrm{~K}^{-1}\left(20-1000^{\circ} \mathrm{C}\right) \\
\text { - } & \text { Specific heat: } 670 \mathrm{~J} / \mathrm{kg}-\mathrm{K}\left(\text { at } 20^{\circ} \mathrm{C}\right)\end{array}$ \\
\hline Chemical compatibility & - Compatible with $\mathrm{SiC}$ at all temperatures \\
\hline
\end{tabular}




\section{Characterization Data for Futurix-MI Experiment}

\begin{tabular}{|c|c|}
\hline Material & $\begin{array}{l}\text { ORNL CVI SiC/SiC Composites } \\
\text { (HNLS-CVI-Ref / TI) }\end{array}$ \\
\hline $\begin{array}{l}\text { Fabrication method, and } \\
\text { method of controlling } \\
\text { repeatability }\end{array}$ & $\begin{array}{l}\text { - Reinforcement with Hi-Nicalon }{ }^{\mathrm{TM}} \text { Type S near-stoichiometric silicon } \\
\text { carbide fiber. } \\
\text { - } \quad \text { Interphase coating with pyrolytic carbon (50-150nm thickness) onto the } \\
\text { fiber surface prior to matrix infiltration. } \\
\text { - Deposition of stoichiometric silicon carbide matrix by isothermal / } \\
\text { isobaric chemical vapor infiltration. }\end{array}$ \\
\hline $\begin{array}{l}\text { Composition and impurity } \\
\text { content }\end{array}$ & $\begin{array}{l}0.42 \% \mathrm{O}, 0.05 \% \mathrm{~N}, 0.06 \% \mathrm{Cl}, 4.6 \text { mass-ppm Fe, } 6.0 \mathrm{ppm} \mathrm{Ni}, 0.13 \mathrm{ppm} \mathrm{Co} \text {, } \\
6.6 \% \text { excess-C, balance } \mathrm{SiC}\end{array}$ \\
\hline Metallographic feature & $\begin{array}{l}\text { - Porosity due to three types of matrix pores; bundle intersections (Type I), } \\
\text { fabric mesh (Type II), interlaminar (Type III) } \\
\text { - Inclusion / precipitation of phases other than SiC or carbon has been } \\
\text { found }\end{array}$ \\
\hline Crystal structure & Beta-SiC in fiber and matrix, glassy carbon in interphase \\
\hline Stoichiometry & $\begin{array}{ll}\text { - } & \text { The matrix is stoichiometric beta-SiC } \\
\text { - } & \text { The fiber consists primarily of beta-SiC } \\
\text { - } & \text { The fiber contains small amount }(\sim 7 \%) \text { of carbon that is present at multi- } \\
& \text { grain junctions of } \mathrm{SiC}\end{array}$ \\
\hline $\begin{array}{l}\text { Details of fiber } \\
\text { reinforcement }\end{array}$ & $\begin{array}{l}\text { - }\left[0 / 90^{\circ}\right] \text { lay-up of two-dimensional plain-weave fabric of Hi-Nicalon }{ }^{\mathrm{TM}} \\
\text { Type S near-stoichiometric silicon carbide fiber produced by Nippon } \\
\text { Carbon Co (Tokyo, Japan). } \\
\text { - } \quad \text { Fabric type / lot: HNS9P2424 / \#AP3711A-01-I8-01 }\end{array}$ \\
\hline Geometry & $\begin{array}{l}\text { - Dimensions and mass of individual specimens are listed in a separate } \\
\text { table. } \\
\text { - } \quad \text { Appearance of specimens is found in a separate set of photographs. }\end{array}$ \\
\hline $\begin{array}{l}\text { Dimensional stability to } \\
1200^{\circ} \mathrm{C}\end{array}$ & $\begin{array}{l}\text { During neutron irradiation, these materials undergo lattice swelling, } \\
\text { which exhibits negative correlation with temperature and tends to } \\
\text { saturate by a neutron fluence of a few displacement-per-atom, in a way } \\
\text { very similar to monolithic crystalline silicon carbide. The expected } \\
\text { magnitude of saturated swelling at } 1000^{\circ} \mathrm{C} \text { is } \sim 0.5 \% \text { volumetric. }\end{array}$ \\
\hline Physical properties & $\begin{array}{ll}\text { - } & \text { Mass density of } 2.52 \mathrm{~g} / \mathrm{cm}^{3}(\sim 82 \% \text { theoretical density) } \\
\text { - } & \text { Thermal conductivity (in-plane): } 28 / 14 \mathrm{~W} / \mathrm{m}-\mathrm{K}\left(\text { at } 20 / 1000^{\circ} \mathrm{C}\right) \\
\text { - } & \text { Thermal conductivity (through-thickness): } 17 / 9 \mathrm{~W} / \mathrm{m}-\mathrm{K}\left(\text { at } 20 / 1000^{\circ} \mathrm{C}\right) \\
\text { - } & \text { Thermal expansion: } 4.5 \times 10^{-6} \mathrm{~K}^{-1}\left(20-1000^{\circ} \mathrm{C}\right) \\
\text { - } & \text { Specific heat: } 670 \mathrm{~J} / \mathrm{kg}-\mathrm{K}\left(\text { at } 20^{\circ} \mathrm{C}\right)\end{array}$ \\
\hline Chemical compatibility & - Compatible with $\mathrm{SiC}$ at all temperatures \\
\hline
\end{tabular}




\section{Characterization Data for Futurix-MI Experiment}

\begin{tabular}{|c|c|}
\hline Material & $\begin{array}{l}\text { ORNL CVI SiC/SiC Composites } \\
\text { (Hybrid-CVI) }\end{array}$ \\
\hline $\begin{array}{l}\text { Fabrication method, and } \\
\text { method of controlling } \\
\text { repeatability }\end{array}$ & $\begin{array}{l}\text { - Reinforcement with Tyranno }{ }^{\mathrm{TM}} \text {-SA Grade-3 near-stoichiometric silicon } \\
\text { carbide fiber and Thornel }{ }^{\mathrm{TM}} \mathrm{P}-120 \mathrm{~S} \text { pitch-based graphite fiber. } \\
\text { - Interphase coating with pyrolytic carbon (50-150nm thickness) onto the } \\
\text { fiber surface prior to matrix infiltration. } \\
\text { - Deposition of stoichiometric silicon carbide matrix by isothermal / } \\
\text { isobaric chemical vapor infiltration. }\end{array}$ \\
\hline $\begin{array}{l}\text { Composition and impurity } \\
\text { content }\end{array}$ & $\begin{array}{l}0.2 \text { mass-\% Al, 0.15\% O, 0.05\% N, 0.06\% Cl, } 3.3 \text { mass-ppm Fe, 2.2ppm Ni, } \\
\text { 28ppm Zr, 0.5ppm Hf, } 5 \text { mass-ppb Co, } 20 \% \text { C, balance SiC }\end{array}$ \\
\hline Metallographic feature & $\begin{array}{l}\text { - Porosity due to matrix pores typical for orthogonal three-dimensional } \\
\text { fiber architecture } \\
\text { - Inclusion / precipitation of phases other than SiC or carbon has been } \\
\text { found }\end{array}$ \\
\hline Crystal structure & $\begin{array}{l}\text { Beta-SiC in Tyranno }{ }^{\mathrm{TM}} \text {-SA fiber and matrix, graphitic carbon in P-120S fiber, } \\
\text { glassy carbon in interphase }\end{array}$ \\
\hline Stoichiometry & $\begin{array}{ll}\text { - } & \text { The matrix is stoichiometric beta-SiC } \\
\text { - } & \text { The Tyranno }{ }^{\mathrm{TM}}-\mathrm{SA} \text { fiber consists primarily of beta-SiC } \\
\text { - } & \text { The Tyranno }{ }^{\mathrm{TM}} \text {-SA fiber contains small amount }(\sim 7 \%) \text { of carbon that is } \\
& \text { present at multi-grain junctions of } \mathrm{SiC}\end{array}$ \\
\hline $\begin{array}{l}\text { Details of fiber } \\
\text { reinforcement }\end{array}$ & $\begin{array}{ll}\text { - } & \text { Orthogonal three-dimensional fabric of Tyranno }{ }^{\mathrm{TM}} \text { SA Grade-3 near- } \\
& \text { stoichiometric silicon carbide fiber, produced by Ube Industries, Ltd } \\
& \text { (Ube, Japan), and Thornel }{ }^{\mathrm{TM}} \mathrm{P}-120 \mathrm{~S} \text { pitch-based graphite fiber, produced } \\
& \text { by (Cytec Engineered Materials, Inc., Anaheim, CA). } \\
\text { - } & \mathrm{X}: \mathrm{Y}: \mathrm{Z}=1: 1: 1 \\
\text { - } & \text { Tyranno } \\
\text { - } & \text { P-120S fiber in trans-thickness (Z) direction }\end{array}$ \\
\hline Geometry & 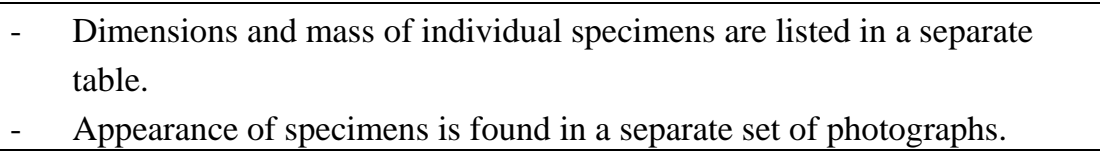 \\
\hline $\begin{array}{l}\text { Dimensional stability to } \\
1200^{\circ} \mathrm{C}\end{array}$ & $\begin{array}{l}\text { During neutron irradiation, this material undergoes lattice swelling, } \\
\text { which exhibits negative correlation with temperature and tends to } \\
\text { saturate by a neutron fluence of a few displacement-per-atom, in a way } \\
\text { very similar to monolithic crystalline silicon carbide. The expected } \\
\text { magnitude of saturated swelling at } 1000^{\circ} \mathrm{C} \text { is } \sim 0.5 \% \text { volumetric. }\end{array}$ \\
\hline Physical properties & $\begin{array}{ll}\text { - } & \text { Mass density of } 2.21 \mathrm{~g} / \mathrm{cm}^{3}(\sim 75 \% \text { theoretical density) } \\
\text { - } & \text { Thermal conductivity (in-plane): } 37 / 16 \mathrm{~W} / \mathrm{m}-\mathrm{K} \text { (at } 20 / 1000^{\circ} \mathrm{C} \text { ) } \\
\text { - } & \left.\text { Thermal conductivity (through-thickness): } 51 \mathrm{~W} / \mathrm{m}-\mathrm{K} \text { (at } 20^{\circ} \mathrm{C}\right) \\
\text { - } & \text { Thermal expansion: } 4.5 \times 10^{-6} \mathrm{~K}^{-1}\left(20-1000^{\circ} \mathrm{C}\right) \\
\text { - } & \left.\text { Specific heat: } 640 \mathrm{~J} / \mathrm{kg}-\mathrm{K} \text { (at } 20^{\circ} \mathrm{C}\right)\end{array}$ \\
\hline Chemical compatibility & - $\quad$ Compatible with $\mathrm{SiC}$ at all temperatures \\
\hline
\end{tabular}




\section{Characterization Data for Futurix-MI Experiment}

\begin{tabular}{|c|c|}
\hline Material & $\begin{array}{l}\text { NITE SiC/SiC Composites } \\
\text { (TySA-NITE) }\end{array}$ \\
\hline $\begin{array}{l}\text { Fabrication method, and } \\
\text { method of controlling } \\
\text { repeatability }\end{array}$ & $\begin{array}{l}\text { - } \quad \text { Reinforcement with Tyranno }{ }^{\mathrm{TM}} \text {-SA Grade-3 near-stoichiometric silicon } \\
\text { carbide fiber. } \\
\text { - Interphase coating with pyrolytic carbon (500nm thickness) onto the } \\
\text { fiber surface prior to matrix sintering. } \\
\text { - Densification of stoichiometric silicon carbide matrix by the proprietary } \\
\text { NITE (nano-infiltration and transient eutectic-phase) process. }\end{array}$ \\
\hline $\begin{array}{l}\text { Composition and impurity } \\
\text { content }\end{array}$ & $\begin{array}{l}0.65 \text { mass-\% } \mathrm{Al}, 2.5 \% \mathrm{Y}, 2.1 \% \mathrm{O}, 0.05 \% \mathrm{~N}, 0.06 \% \mathrm{Cl}, 3.3 \text { mass-ppm Fe, } \\
\text { 2.2ppm Ni, 28ppm Zr, 0.5ppm Hf, } 5 \text { mass-ppb Co, 0.8\% excess Si, 9.6\% } \\
\text { excess C, balance } \mathrm{SiC}\end{array}$ \\
\hline Metallographic feature & $\begin{array}{l}\text { - } \begin{array}{l}\text { Porosity due to finely and uniformly distributed matrix pores } \\
\text { - }\end{array} \text { The matrix contains oxide phases; primarily } \mathrm{Y}_{3} \mathrm{Al}_{5} \mathrm{O}_{12} \text {, other oxide } \\
\text { phases consist of } \mathrm{Al}, \mathrm{Y}, \mathrm{Si} \text {, and } \mathrm{O} \text {. }\end{array}$ \\
\hline Crystal structure & Primarily beta-SiC in fiber and matrix, glassy carbon in interphase \\
\hline Stoichiometry & $\begin{array}{l}\text { - } \quad \text { The matrix } \mathrm{SiC} \text { is stoichiometric beta-phase } \\
\text { - } \quad \text { The matrix contains }<10 \% \text { of oxide phases which are present at multi- } \\
\text { grain junctions of } \mathrm{SiC} \text { and between the matrix } \mathrm{SiC} \text { grains and interphases } \\
\text { - } \mathrm{SiC} \text { in the fiber is stoichiometric beta-phase } \\
\text { - } \quad \text { The fiber contains small amount ( } 5 \%) \text { of carbon that is present at multi- } \\
\text { grain junctions of } \mathrm{SiC}\end{array}$ \\
\hline $\begin{array}{l}\text { Details of fiber } \\
\text { reinforcement }\end{array}$ & $\begin{array}{l}\text { - Uni-directional reinforcement with proprietary Tyranno }{ }^{\mathrm{TM}} \text {-SAK near- } \\
\text { stoichiometric silicon carbide fiber produced by Ube Industries, Ltd } \\
\text { (Ube, Japan) }\end{array}$ \\
\hline Geometry & $\begin{array}{l}\text { - Dimensions and mass of individual specimens are listed in a separate } \\
\text { table. } \\
\text { - } \quad \text { Appearance of specimens is found in a separate set of photographs. }\end{array}$ \\
\hline $\begin{array}{l}\text { Dimensional stability to } \\
1200^{\circ} \mathrm{C}\end{array}$ & $\begin{array}{l}\text { During neutron irradiation, this material undergoes lattice swelling, } \\
\text { which exhibits negative correlation with temperature and tends to } \\
\text { saturate by a neutron fluence of a few displacement-per-atom, in a way } \\
\text { very similar to monolithic crystalline silicon carbide. The expected } \\
\text { magnitude of saturated swelling at } 1000^{\circ} \mathrm{C} \text { is } \sim 0.5 \% \text { volumetric. }\end{array}$ \\
\hline Physical properties & $\begin{array}{ll}\text { - } & \text { Mass density: } 2.99 \mathrm{~g} / \mathrm{cm}^{3}(\sim 97 \% \text { theoretical density) } \\
\text { - } & \text { Thermal conductivity (through-thickness): } 74 \mathrm{~W} / \mathrm{m}-\mathrm{K}\left(\text { at } 20^{\circ} \mathrm{C}\right) \\
\text { - } & \text { Thermal expansion: } 4.5 \times 10^{-6} \mathrm{~K}^{-1}\left(20-1000^{\circ} \mathrm{C}\right) \\
\text { - } & \left.\text { Specific heat: } 660 \mathrm{~J} / \mathrm{kg}-\mathrm{K} \text { (at } 20^{\circ} \mathrm{C}\right)\end{array}$ \\
\hline Chemical compatibility & - $\quad$ Compatible with $\mathrm{SiC}$ at all temperatures \\
\hline
\end{tabular}




\section{Characterization Data for Futurix-MI Experiment}

\begin{tabular}{|c|c|}
\hline Material & Rohm and Haas CVD SiC \\
\hline $\begin{array}{l}\text { Fabrication method, and } \\
\text { method of controlling } \\
\text { repeatability }\end{array}$ & $\begin{array}{l}\text { - Standard resistivity grade of ultra-high purity CVD (chemically vapor } \\
\text { deposited) SiC produced by Rohm and Haas Advanced Materials } \\
\text { (Woburn, MA, USA) }\end{array}$ \\
\hline $\begin{array}{l}\text { Composition and impurity } \\
\text { content }\end{array}$ & $>99.9995 \% \mathrm{SiC}$ \\
\hline Metallographic feature & - $\quad$ Crystal grains elongated along the CVD growth direction \\
\hline Crystal structure & - $\quad$ Beta-SiC \\
\hline Stoichiometry & - $\quad$ This material is stoichiometric \\
\hline $\begin{array}{l}\text { Details of fiber } \\
\text { reinforcement }\end{array}$ & Not applicable \\
\hline Geometry & 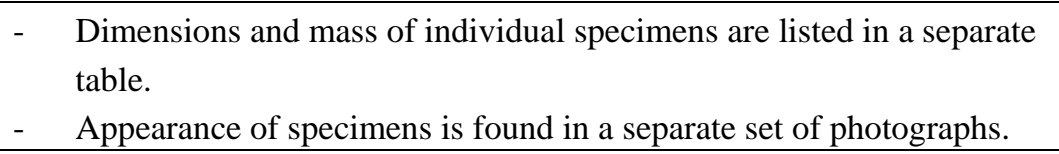 \\
\hline $\begin{array}{l}\text { Dimensional stability to } \\
1200^{\circ} \mathrm{C}\end{array}$ & $\begin{array}{l}\text { During neutron irradiation, these materials undergo lattice swelling, } \\
\text { which exhibits negative correlation with temperature and tends to } \\
\text { saturate by a neutron fluence of a few displacement-per-atom. The } \\
\text { expected magnitude of saturated swelling at } 1000^{\circ} \mathrm{C} \text { is } \sim 0.5 \% \\
\text { volumetric. }\end{array}$ \\
\hline Physical properties & $\begin{array}{ll}\text { - } & \text { Mass density: } 3.21 \mathrm{~g} / \mathrm{cm}^{3}(100 \% \text { theoretical density) } \\
\text { - } & \text { Thermal conductivity: } 333 / 78 \mathrm{~W} / \mathrm{m}-\mathrm{K}\left(\text { at } 0 / 1000^{\circ} \mathrm{C}\right) \\
\text { - } & \text { Thermal expansion: } 4.5 \times 10^{-6} \mathrm{~K}^{-1}\left(20-1000^{\circ} \mathrm{C}\right) \\
\text { - } & \text { Specific heat: } 574 / 1251 \mathrm{~J} / \mathrm{kg}-\mathrm{K}\left(\text { at } 0 / 1000^{\circ} \mathrm{C}\right)\end{array}$ \\
\hline Chemical compatibility & - $\quad$ Compatible with $\mathrm{SiC}$ at all temperatures \\
\hline
\end{tabular}




\section{Characterization Data for Futurix-MI Experiment}

\begin{tabular}{|c|c|}
\hline Material & HAST Single-Crystal 3C-SiC \\
\hline $\begin{array}{l}\text { Fabrication method, and } \\
\text { method of controlling } \\
\text { repeatability }\end{array}$ & $\begin{array}{l}\text { - Standard resistivity grade of monocrystalline CVD (chemically vapor } \\
\text { deposited) 3C-SiC produced by HAST; Hoya Advanced Semiconductor } \\
\text { Technologies Co., Ltd. (Sagamihara, Japan) }\end{array}$ \\
\hline $\begin{array}{l}\text { Composition and impurity } \\
\text { content }\end{array}$ & $\sim 10$ at.ppm N, balance $\mathrm{SiC}$ \\
\hline Metallographic feature & Not applicable \\
\hline Crystal structure & - $\quad$ Beta-SiC, $\{100\}$ surface orientation \\
\hline Stoichiometry & - $\quad$ This material is stoichiometric \\
\hline $\begin{array}{l}\text { Details of fiber } \\
\text { reinforcement }\end{array}$ & Not applicable \\
\hline Geometry & 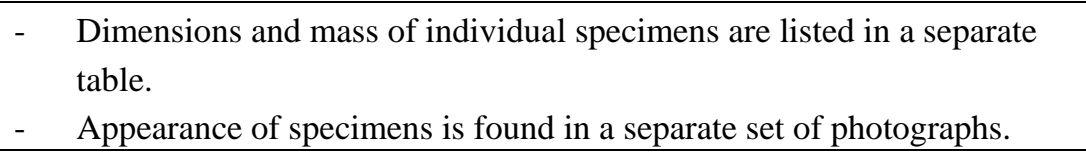 \\
\hline $\begin{array}{l}\text { Dimensional stability to } \\
1200^{\circ} \mathrm{C}\end{array}$ & $\begin{array}{l}\text { During neutron irradiation, these materials undergo lattice swelling, } \\
\text { which exhibits negative correlation with temperature and tends to } \\
\text { saturate by a neutron fluence of a few displacement-per-atom. The } \\
\text { expected magnitude of saturated swelling at } 1000^{\circ} \mathrm{C} \text { is } \sim 0.5 \% \\
\text { volumetric. }\end{array}$ \\
\hline Physical properties & - $\quad$ Mass density: $3.21 \mathrm{~g} / \mathrm{cm}^{3}(100 \%$ theoretical density $)$ \\
\hline Chemical compatibility & - $\quad$ Compatible with $\mathrm{SiC}$ at all temperatures \\
\hline
\end{tabular}




\section{Characterization Data for Futurix-MI Experiment}

\begin{tabular}{|c|c|}
\hline Material & NITE LPS-SiC \\
\hline $\begin{array}{l}\text { Fabrication method, and } \\
\text { method of controlling } \\
\text { repeatability }\end{array}$ & $\begin{array}{l}\text { - Matrix material for NITE SiC/SiC composite in a form of monolithic SiC } \\
\text { ceramic } \\
\text { - } \begin{array}{l}\text { Produced through liquid-phase sintering (LPS); the process condition is } \\
\text { proprietary }\end{array}\end{array}$ \\
\hline $\begin{array}{l}\text { Composition and impurity } \\
\text { content }\end{array}$ & 1.5 mass-\% Al, 3.0\% Y, 3.9\% O, 1.6\% excess-Si, balance SiC \\
\hline Metallographic feature & $\begin{array}{l}\text { - } \quad \text { Porosity due to finely and uniformly distributed pores } \\
\text { - } \quad \text { Grain sizes are } 200-1000 \mathrm{~nm} \text {. } \\
\text { - } \quad \text { The matrix contains oxide phases; primarily } \mathrm{Y}_{3} \mathrm{Al}_{5} \mathrm{O}_{12} \text {, other oxide } \\
\text { phases consist of } \mathrm{Al}, \mathrm{Y}, \mathrm{Si} \text {, and } \mathrm{O} \text {. }\end{array}$ \\
\hline Crystal structure & - $\quad$ Beta-SiC \\
\hline Stoichiometry & $\begin{array}{ll}\text { - } & \text { This material is primarily stoichiometric beta-phase } \mathrm{SiC} \\
\text { - } & \text { The material contains }<10 \% \text { of oxide phases which are present at multi- } \\
\text { grain junctions of } \mathrm{SiC}\end{array}$ \\
\hline $\begin{array}{l}\text { Details of fiber } \\
\text { reinforcement }\end{array}$ & Not applicable \\
\hline Geometry & $\begin{array}{l}\text { - Dimensions and mass of individual specimens are listed in a separate } \\
\text { table. } \\
\text { - } \quad \text { Appearance of specimens is found in a separate set of photographs. }\end{array}$ \\
\hline $\begin{array}{l}\text { Dimensional stability to } \\
1200^{\circ} \mathrm{C}\end{array}$ & $\begin{array}{l}\text { During neutron irradiation, these materials undergo lattice swelling, } \\
\text { which exhibits negative correlation with temperature and tends to } \\
\text { saturate by a neutron fluence of a few displacement-per-atom. The } \\
\text { expected magnitude of saturated swelling at } 1000^{\circ} \mathrm{C} \text { is } \sim 0.5 \% \\
\text { volumetric. }\end{array}$ \\
\hline Physical properties & - $\quad$ Mass density: $3.08 \mathrm{~g} / \mathrm{cm}^{3}(\sim 96 \%$ theoretical density) \\
\hline Chemical compatibility & - $\quad$ Compatible with SiC at all temperatures \\
\hline
\end{tabular}




\section{Attachment 4}

List of ORNL Silicon Carbide Specimens 


\begin{tabular}{|c|c|c|c|c|c|c|c|c|c|c|}
\hline \multirow{2}{*}{ Type } & \multirow{2}{*}{$\begin{array}{l}\text { Material } \\
\text { Category }\end{array}$} & \multirow{2}{*}{ Material } & \multirow{2}{*}{ ID } & \multirow{2}{*}{$\begin{array}{c}\text { Alternate } \\
\text { ID }\end{array}$} & \multirow{2}{*}{ Use } & \multicolumn{4}{|c|}{ Dimensions (mm) } & \multirow{2}{*}{$\begin{array}{l}\text { Mass } \\
\text { (q) }\end{array}$} \\
\hline & & & & & & $\mathrm{L}$ & W & $\mathrm{T}$ & Dia. & \\
\hline $\mathrm{BB}$ & NITE SiC & TySA-NITE & NT01 & BB25-01 & Irradiation & 25.17 & 2.49 & 2.00 & - & 0.3704 \\
\hline BB & NITE SiC & TySA-NITE & NT02 & BB25-02 & Irradiation & 25.17 & 2.49 & 2.00 & - & 0.3727 \\
\hline $\mathrm{BB}$ & NITE SiC & TySA-NITE & NT03 & BB25-03 & Irradiation & 25.18 & 2.48 & 2.00 & - & 0.3760 \\
\hline $\mathrm{BB}$ & NITE SiC & TySA-NITE & NT04 & BB25-04 & Irradiation & 25.20 & 2.49 & 2.00 & - & 0.3783 \\
\hline $\mathrm{BB}$ & NITE SiC & TySA-NITE & NT05 & BB25-05 & Irradiation & 25.20 & 2.49 & 2.00 & - & 0.3770 \\
\hline BB & NITE SiC & TySA-NITE & NT06 & BB25-06 & Irradiation & 25.20 & 2.50 & 2.01 & - & 0.3781 \\
\hline BB & NITE SiC & TySA-NITE & NT07 & BB25-07 & Control & 25.20 & 2.48 & 2.00 & - & 0.3800 \\
\hline $\mathrm{BB}$ & NITE SiC & TySA-NITE & NT08 & BB25-08 & Control & 25.20 & 2.48 & 2.01 & - & 0.3794 \\
\hline $\mathrm{BB}$ & NITE SiC & TySA-NITE & NT09 & BB25-09 & Control & 25.22 & 2.50 & 2.01 & - & 0.3756 \\
\hline $\mathrm{BB}$ & NITE SiC & TySA-NITE & NT10 & BB25-10 & Control & 25.20 & 2.49 & 2.00 & - & 0.3785 \\
\hline $\mathrm{BB}$ & NITE SiC & TySA-NITE & NT11 & BB25-11 & Control & 25.19 & 2.49 & 2.01 & - & 0.3767 \\
\hline $\mathrm{BB}$ & NITE SiC & TySA-NITE & NT12 & BB25-12 & Control & 25.18 & 2.50 & 2.01 & - & 0.3802 \\
\hline CYL & NITE SiC & TySA-NITE & NT21 & CYL-01 & Irradiation & 10.04 & - & - & 2.95 & 0.1995 \\
\hline CYL & NITE SiC & TySA-NITE & NT22 & CYL-02 & Con & 10.03 & - & - & 2.94 & 0.1974 \\
\hline TDD & NITE SiC & TySA-NITE & NT31 & TD8-01 & Irradiation & - & - & 2.01 & 7.88 & 0.2935 \\
\hline TDD & NITE SiC & TySA-NITE & NT32 & TD8-02 & Irradiation & - & - & 2.01 & 7.91 & 0.2963 \\
\hline TDD & NITE SiC & TySA-NITE & NT33 & TD8-03 & Irradiation & - & - & 2.00 & 7.89 & 0.2983 \\
\hline TDD & NITE SiC & TySA-NITE & NT34 & TD8-04 & Control & - & - & 2.00 & 7.88 & 0.2943 \\
\hline TDD & NITE SiC & TySA-NITE & NT35 & TD8-05 & Control & - & - & 2.00 & 7.87 & 0.2948 \\
\hline TDD & NITE SiC & TySA-NITE & NT36 & TD8-06 & Control & - & - & 2.00 & 7.88 & 0.2914 \\
\hline TDD & NITE SiC & NITE Matrix SiC & LP31 & TD8-07 & Irradiation & - & - & 1.94 & 7.91 & 0.2839 \\
\hline TDD & NITE SiC & NITE Matrix SiC & LP32 & TD8-01 & Irradiation & - & - & 1.94 & 7.89 & 0.2809 \\
\hline TDD & NITE SiC & NITE Matrix SiC & LP33 & TD8-09 & Irradiation & - & - & 1.95 & 7.90 & 0.2813 \\
\hline TDD & NITE SiC & NITE Matrix SiC & LP34 & TD8-10 & Control & - & - & 1.94 & 7.86 & 0.2807 \\
\hline TDD & NITE SiC & NITE Matrix SiC & LP35 & TD8-11 & Control & - & - & 1.93 & 7.89 & 0.2841 \\
\hline TDD & NITE SiC & NITE Matrix SiC & LP36 & TD8-12 & Control & - & - & 1.94 & 7.87 & 0.2822 \\
\hline TDD & NITE SiC & CVD SiC R\&H & CD31 & TD8-13 & Irradiation & - & - & 2.01 & 7.88 & 0.3121 \\
\hline TDD & NITE SiC & CVD SiC R\&H & CD32 & TD8-14 & Irradiation & - & - & 2.00 & 7.88 & 0.3127 \\
\hline TDD & NITE SiC & CVD SiC R\&H & CD33 & TD8-15 & Control & - & - & 1.94 & 7.83 & 0.3032 \\
\hline TDD & NITE SiC & CVD SiC R\&H & CD34 & TD8-16 & Control & - & - & 1.95 & 7.88 & 0.3025 \\
\hline TDD & NITE SiC & Hybrid-CVI & HC31 & - & Irradiation & - & - & 1.98 & 7.93 & 0.2260 \\
\hline TDD & NITE SiC & Hybrid-CVI & HC32 & - & Irradiation & - & - & 2.01 & 7.94 & 0.2100 \\
\hline TDD & NITE SiC & Hybrid-CVI & HC33 & - & Control & - & - & 2.04 & 7.93 & 0.2180 \\
\hline TDD & NITE SiC & Hybrid-CVI & HC34 & - & Control & - & - & 2.02 & 7.94 & 0.2250 \\
\hline
\end{tabular}




\begin{tabular}{|c|c|c|c|c|c|c|c|c|c|c|}
\hline \multirow{2}{*}{ Type } & \multirow{2}{*}{$\begin{array}{l}\text { Material } \\
\text { Category }\end{array}$} & \multirow{2}{*}{ Material } & \multirow{2}{*}{ ID } & \multirow{2}{*}{$\begin{array}{c}\text { Alternate } \\
\text { ID }\end{array}$} & \multirow{2}{*}{ Use } & \multicolumn{4}{|c|}{ Dimensions $(\mathrm{mm})$} & \multirow{2}{*}{$\begin{array}{c}\text { Mass } \\
\text { (g) }\end{array}$} \\
\hline & & & & & & $\mathrm{L}$ & W & $\mathrm{T}$ & Dia. & \\
\hline TEM & NITE SiC & NITE Matrix SiC & LP41 & TE3-01 & Irradiation & - & - & 0.150 & 2.97 & 0.0032 \\
\hline TEM & NITE SiC & NITE Matrix SiC & LP42 & TE3-02 & Irradiation & - & - & 0.150 & 2.97 & 0.0032 \\
\hline TEM & NITE SiC & NITE Matrix SiC & LP43 & TE3-03 & Irradiation & - & - & 0.150 & 2.97 & 0.0032 \\
\hline TEM & NITE SiC & NITE Matrix SiC & LP44 & TE3-04 & Irradiation & - & - & 0.150 & 2.97 & 0.0032 \\
\hline TEM & NITE SiC & NITE Matrix SiC & LP45 & TE3-05 & Irradiation & - & - & 0.150 & 2.97 & 0.0032 \\
\hline TEM & NITE SiC & NITE Matrix SiC & LP46 & TE3-06 & Irradiation & - & - & 0.150 & 2.97 & 0.0032 \\
\hline TEM & NITE SiC & NITE Matrix SiC & LP47 & TE3-07 & Irradiation & - & - & 0.150 & 2.97 & 0.0032 \\
\hline TEM & NITE SiC & NITE Matrix SiC & LP48 & TE3-08 & Irradiation & - & - & 0.150 & 2.97 & 0.0032 \\
\hline TEM & NITE SiC & NITE Matrix SiC & LP49 & TE3-09 & Irradiation & - & - & 0.150 & 2.97 & 0.0032 \\
\hline TEM & NITE SiC & NITE Matrix SiC & LP50 & TE3-10 & Irradiation & - & - & 0.150 & 2.97 & 0.0032 \\
\hline TEM & NITE SiC & NITE Matrix SiC & LP51 & TE3-11 & Control & - & - & 0.150 & 2.97 & 0.0032 \\
\hline TEM & NITE SiC & NITE Matrix SiC & LP52 & TE3-12 & Control & - & - & 0.150 & 2.97 & 0.0032 \\
\hline TEM & NITE SiC & NITE Matrix SiC & LP53 & TE3-13 & Control & - & - & 0.150 & 2.97 & 0.0032 \\
\hline TEM & NITE SiC & NITE Matrix SiC & LP54 & TE3-14 & Control & - & - & 0.150 & 2.97 & 0.0032 \\
\hline TEM & NITE SiC & NITE Matrix SiC & LP55 & TE3-15 & Control & - & - & 0.150 & 2.97 & 0.0032 \\
\hline TEM & NITE SiC & NITE Matrix SiC & LP56 & TE3-16 & Control & - & - & 0.150 & 2.97 & 0.0032 \\
\hline TEM & NITE SiC & NITE Matrix SiC & LP57 & TE3-17 & Control & - & - & 0.150 & 2.97 & 0.0032 \\
\hline TEM & NITE SiC & NITE Matrix SiC & LP58 & TE3-18 & Control & - & - & 0.150 & 2.97 & 0.0032 \\
\hline TEM & NITE SiC & NITE Matrix SiC & LP59 & TE3-19 & Control & - & - & 0.150 & 2.97 & 0.0032 \\
\hline TEM & NITE SiC & NITE Matrix SiC & LP60 & TE3-20 & Control & - & - & 0.150 & 2.97 & 0.0032 \\
\hline
\end{tabular}




\begin{tabular}{|c|c|c|c|c|c|c|c|c|c|c|}
\hline \multirow{2}{*}{ Type } & \multirow{2}{*}{$\begin{array}{l}\text { Material } \\
\text { Category }\end{array}$} & \multirow{2}{*}{ Material } & \multirow{2}{*}{ ID } & \multirow{2}{*}{$\begin{array}{c}\text { Alternate } \\
\text { ID }\end{array}$} & \multirow{2}{*}{ Use } & \multicolumn{4}{|c|}{ Dimensions (mm) } & \multirow{2}{*}{$\begin{array}{c}\text { Mass } \\
(\mathrm{g})\end{array}$} \\
\hline & & & & & & $\mathrm{L}$ & W & $\mathrm{T}$ & Dia. & \\
\hline BB & ORNL SiC & HNLS-CVI-Ref & SR01 & - & Irradiation & 25.00 & 2.50 & 2.01 & - & 0.2950 \\
\hline BB & ORNL SiC & HNLS-CVI-Ref & SR02 & - & Irradiation & 24.99 & 2.50 & 2.00 & - & 0.2890 \\
\hline BB & ORNL SiC & HNLS-CVI-Ref & SR03 & - & Irradiation & 25.01 & 2.49 & 2.01 & - & 0.2920 \\
\hline BB & ORNL SiC & HNLS-CVI-Ref & SR04 & - & Irradiation & 25.00 & 2.50 & 2.01 & - & 0.2890 \\
\hline BB & ORNL SiC & HNLS-CVI-Ref & SR05 & - & Irradiation & 25.00 & 2.49 & 2.01 & - & 0.2960 \\
\hline $\mathrm{BB}$ & ORNL SiC & HNLS-CVI-Ref & SR06 & - & Irradiation & 25.00 & 2.49 & 2.00 & - & 0.2920 \\
\hline $\mathrm{BB}$ & ORNL SiC & HNLS-CVI-Ref & SR07 & - & Control & 25.00 & 2.50 & 2.00 & - & 0.2920 \\
\hline $\mathrm{BB}$ & ORNL SiC & HNLS-CVI-Ref & SR08 & - & Control & 25.00 & 2.48 & 2.01 & - & 0.2940 \\
\hline $\mathrm{BB}$ & ORNL SiC & HNLS-CVI-Ref & SR09 & - & Control & 24.99 & 2.50 & 2.01 & - & 0.2880 \\
\hline $\mathrm{BB}$ & ORNL SiC & HNLS-CVI-Ref & SR10 & - & Control & 24.99 & 2.48 & 2.00 & - & 0.2990 \\
\hline BB & ORNL SiC & HNLS-CVI-Ref & SR11 & - & Control & 24.99 & 2.50 & 2.00 & - & 0.2870 \\
\hline $\mathrm{BB}$ & ORNL SiC & HNLS-CVI-Ref & SR12 & - & Control & 25.00 & 2.49 & 2.01 & - & 0.2900 \\
\hline $\mathrm{BB}$ & ORNL SiC & HNLS-CVI-TI & ST01 & - & Irradiation & 25.00 & 2.48 & 2.01 & - & 0.2910 \\
\hline $\mathrm{BB}$ & ORNL SiC & HNLS-CVI-TI & ST02 & - & Irradiation & 25.00 & 2.48 & 2.00 & - & 0.2860 \\
\hline $\mathrm{BB}$ & ORNL SiC & HNLS-CVI-TI & ST03 & - & Irradiation & 25.00 & 2.50 & 2.00 & - & 0.2820 \\
\hline BB & ORNL SiC & HNLS-CVI-TI & ST04 & - & Irradiation & 25.00 & 2.49 & 2.00 & - & 0.2790 \\
\hline BB & ORNL SiC & HNLS-CVI-TI & ST05 & - & Irradiation & 25.00 & 2.49 & 1.96 & - & 0.2700 \\
\hline $\mathrm{BB}$ & ORNL SiC & HNLS-CVI-TI & ST06 & - & Irradiation & 25.00 & 2.50 & 2.00 & - & 0.2790 \\
\hline $\mathrm{BB}$ & ORNL SiC & HNLS-CVI-TI & ST07 & - & Control & 24.99 & 2.50 & 2.00 & - & 0.2810 \\
\hline $\mathrm{BB}$ & ORNL SiC & HNLS-CVI-TI & ST08 & - & Control & 25.00 & 2.50 & 2.01 & - & 0.2920 \\
\hline $\mathrm{BB}$ & ORNL SiC & & & - & & 25.00 & 2.50 & 2.00 & - & 0.2920 \\
\hline $\mathrm{BB}$ & ORNL SiC & CVI-TI & ST10 & - & Control & 24.99 & 2.49 & 2.01 & - & 0.2910 \\
\hline $\mathrm{BB}$ & ORNL SiC & CVI-TI & ST11 & - & Control & 25.00 & 2.48 & 2.00 & - & 0.2840 \\
\hline BB & ORNL SiC & CVI-TI & ST12 & - & Con & 25.00 & 2.49 & 2.00 & - & 0.2890 \\
\hline CYL & ORNL SiC & HNLS-CVI-TI & ST21 & - & Irradiation & 9.97 & - & - & 2.99 & 0.1740 \\
\hline $\mathrm{CYL}$ & ORNL SiC & HNLS-CVI-TI & ST22 & - & Control & 9.99 & - & - & 2.94 & 0.1630 \\
\hline TDD & ORNL SiC & TySA-CVI-Ref & TR31 & - & Irradiation & - & - & 2.03 & 7.94 & 0.2660 \\
\hline TDD & ORNL SiC & TySA-CVI-Ref & TR32 & - & Irradiation & - & - & 2.04 & 7.93 & 0.2660 \\
\hline TDD & ORNL SiC & TySA-CVI-Ref & TR33 & - & Control & - & - & 2.02 & 7.93 & 0.2670 \\
\hline TDD & ORNL SiC & TySA-CVI-Ref & TR34 & - & Control & - & - & 2.00 & 7.93 & 0.2700 \\
\hline TDD & ORNL SiC & TySA-CVI-TI & TT31 & - & Irradiation & - & - & 2.07 & 7.92 & 0.2540 \\
\hline TDD & ORNL SiC & TySA-CVI-TI & TT32 & - & Irradiation & - & - & 1.98 & 7.93 & 0.2680 \\
\hline TDD & ORNL SiC & & TT33 & - & & - & - & 2.02 & 7.93 & 0.2800 \\
\hline TDD & ORNL SiC & & TT & - & & - & - & 2.01 & 7.9 & 0.2750 \\
\hline TDD & ORNL SiC & TySA-CVI-TF & TF31 & - & Irradiation & - & - & 2.01 & 7.93 & 0.2630 \\
\hline TDD & ORNL SiC & TySA-CVI-TF & TF32 & - & Irradiation & - & - & 2.02 & 7.92 & 0.2690 \\
\hline TDD & ORNL SiC & TySA-CVI-TF & TF33 & - & Control & - & - & 2.01 & 7.92 & 0.2610 \\
\hline TDD & ORNL SiC & TySA-CVI-TF & TF34 & - & Control & - & - & 2.02 & 7.92 & 0.2590 \\
\hline TDD & ORNL SiC & HNLS-CVI-Ref & SR31 & - & Irradiation & - & - & 2.05 & 7.92 & 0.2540 \\
\hline TDD & ORNL SiC & HNLS-CVI-Ref & SR32 & - & Irradiation & - & - & 2.03 & 7.92 & 0.2550 \\
\hline TDD & ORNL SiC & HNLS-CVI-Ref & SR33 & - & Control & - & - & 2.03 & 7.93 & 0.2490 \\
\hline TDD & ORNL SiC & HNLS-CVI-Ref & SR34 & - & Control & - & - & 2.05 & 7.93 & 0.2490 \\
\hline TDD & ORNL SiC & HNLS-CVI-TI & ST31 & - & Irradiation & - & - & 2.04 & 7.95 & 0.2600 \\
\hline TDD & ORNL SiC & HNLS-CVI-TI & ST32 & - & Irradiation & - & - & 2.04 & 7.93 & 0.2570 \\
\hline TDD & ORNL SiC & HNLS-CVI-TI & ST33 & - & & - & - & 2.03 & 7.93 & 0.2500 \\
\hline TDD & ORNL SiC & HNLS-CVI-TI & ST34 & - & Control & - & - & 2.06 & 7.93 & 0.2550 \\
\hline
\end{tabular}




\begin{tabular}{|c|c|c|c|c|c|c|c|c|c|c|}
\hline \multirow{2}{*}{ Type } & \multirow{2}{*}{$\begin{array}{l}\text { Material } \\
\text { Category }\end{array}$} & \multirow{2}{*}{ Material } & \multirow{2}{*}{ ID } & \multirow{2}{*}{$\begin{array}{c}\text { Alternate } \\
\text { ID }\end{array}$} & \multirow{2}{*}{ Use } & \multicolumn{4}{|c|}{ Dimensions $(\mathrm{mm})$} & \multirow{2}{*}{$\begin{array}{c}\text { Mass } \\
(\mathrm{g})\end{array}$} \\
\hline & & & & & & $\mathrm{L}$ & W & $\mathrm{T}$ & Dia. & \\
\hline TEM & ORNL SiC & CVD SiC R\&H & CD41 & - & Irradiation & - & - & 0.13 & 2.92 & 0.0028 \\
\hline TEM & ORNL SiC & CVD SiC R\&H & CD42 & - & Irradiation & - & - & 0.13 & 2.92 & 0.0028 \\
\hline TEM & ORNL SiC & CVD SiC R\&H & CD43 & - & Irradiation & - & - & 0.13 & 2.92 & 0.0028 \\
\hline TEM & ORNL SiC & CVD SiC R\&H & CD44 & - & Irradiation & - & - & 0.13 & 2.92 & 0.0028 \\
\hline TEM & ORNL SiC & CVD SiC R\&H & CD45 & - & Irradiation & - & - & 0.13 & 2.92 & 0.0028 \\
\hline TEM & ORNL SiC & CVD SiC R\&H & CD46 & - & Irradiation & - & - & 0.13 & 2.92 & 0.0028 \\
\hline TEM & ORNL SiC & CVD SiC R\&H & CD47 & - & Irradiation & - & - & 0.13 & 2.92 & 0.0028 \\
\hline TEM & ORNL SiC & CVD SiC R\&H & CD48 & - & Irradiation & - & - & 0.13 & 2.92 & 0.0028 \\
\hline TEM & ORNL SiC & CVD SiC R\&H & CD49 & - & Irradiation & - & - & 0.13 & 2.92 & 0.0028 \\
\hline TEM & ORNL SiC & CVD SiC R\&H & CD50 & - & Irradiation & - & - & 0.13 & 2.92 & 0.0028 \\
\hline TEM & ORNL SiC & CVD SiC R\&H & CD51 & - & Irradiation & - & - & 0.13 & 2.92 & 0.0028 \\
\hline TEM & ORNL SiC & CVD SiC R\&H & CD52 & - & Irradiation & - & - & 0.13 & 2.92 & 0.0028 \\
\hline TEM & ORNL SiC & CVD SiC R\&H & CD53 & - & Control & - & - & 0.13 & 2.92 & 0.0028 \\
\hline TEM & ORNL SiC & CVD SiC R\&H & CD54 & - & Control & - & - & 0.13 & 2.92 & 0.0028 \\
\hline TEM & ORNL SiC & CVD SiC R\&H & CD55 & - & Control & - & - & 0.13 & 2.92 & 0.0028 \\
\hline TEM & ORNL SiC & CVD SiC R\&H & CD56 & - & Control & - & - & 0.13 & 2.92 & 0.0028 \\
\hline TEM & ORNL SiC & CVD SiC R\&H & CD57 & - & Control & - & - & 0.13 & 2.92 & 0.0028 \\
\hline TEM & ORNL SiC & CVD SiC R\&H & CD58 & - & Control & - & - & 0.13 & 2.92 & 0.0028 \\
\hline TEM & ORNL SiC & CVD SiC R\&H & CD59 & - & Control & - & - & 0.13 & 2.92 & 0.0028 \\
\hline TEM & ORNL SiC & CVD SiC R\&H & CD60 & - & Control & - & - & 0.13 & 2.92 & 0.0028 \\
\hline TEM & ORNL SiC & SC-SiC & SX41 & - & Irradiation & - & - & 0.27 & 2.90 & 0.0056 \\
\hline TEM & ORNL SiC & SC-SiC & SX42 & - & Irradiation & - & - & 0.27 & 2.90 & 0.0056 \\
\hline TEM & ORNL SiC & SC-SiC & SX43 & - & Irradiation & - & - & 0.27 & 2.90 & 0.0056 \\
\hline TEM & ORNL SiC & SC-SiC & SX44 & - & Irradiation & - & - & 0.27 & 2.90 & 0.0056 \\
\hline TEM & ORNL SiC & SC-SiC & SX45 & - & Irradiation & - & - & 0.27 & 2.90 & 0.0056 \\
\hline TEM & ORNL SiC & SC-SiC & SX46 & - & Irradiation & - & - & 0.27 & 2.90 & 0.0056 \\
\hline TEM & ORNL SiC & SC-SiC & SX47 & - & Irradiation & - & - & 0.27 & 2.90 & 0.0056 \\
\hline TEM & ORNL SiC & SC-SiC & SX48 & - & Irradiation & - & - & 0.27 & 2.90 & 0.0056 \\
\hline TEM & ORNL SiC & SC-SiC & SX49 & - & Control & - & - & 0.27 & 2.90 & 0.0056 \\
\hline TEM & ORNL SiC & SC-SiC & SX50 & - & Control & - & - & 0.27 & 2.90 & 0.0056 \\
\hline
\end{tabular}




\section{Attachment 5}

List of ORNL Molybdenum Specimens 


\begin{tabular}{|c|c|c|c|c|c|c|c|c|c|c|}
\hline \multirow{2}{*}{ Type } & \multirow{2}{*}{$\begin{array}{l}\text { Material } \\
\text { Category }\end{array}$} & \multirow{2}{*}{ Material } & \multirow{2}{*}{ ID } & \multirow{2}{*}{$\begin{array}{c}\text { Alternate } \\
\text { ID }\end{array}$} & \multirow{2}{*}{ Use } & \multicolumn{4}{|c|}{ Dimensions $(\mathrm{mm})$} & \multirow{2}{*}{$\begin{array}{c}\text { Mass } \\
(\mathrm{g})\end{array}$} \\
\hline & & & & & & $\mathrm{L}$ & W & $\mathrm{T}$ & Dia. & \\
\hline TEM & ORNL Mo & LCAC Moly & L1 & - & Irradiation & - & - & 0.171 & 2.991 & 0.012 \\
\hline TEM & ORNL Mo & LCAC Moly & L2 & - & Irradiation & - & - & 0.182 & 2.992 & 0.012 \\
\hline TEM & ORNL Mo & LCAC Moly & L3 & - & Irradiation & - & - & 0.179 & 2.994 & 0.012 \\
\hline TEM & ORNL Mo & LCAC Moly & L4 & - & Irradiation & - & - & 0.181 & 2.991 & 0.012 \\
\hline TEM & ORNL Mo & LCAC Moly & L5 & - & Irradiation & - & - & 0.183 & 2.992 & 0.012 \\
\hline TEM & ORNL Mo & LCAC Moly & L6 & - & Irradiation & - & - & 0.181 & 2.981 & 0.012 \\
\hline TEM & ORNL Mo & LCAC Moly & L7 & - & Irradiation & - & - & 0.179 & 2.990 & 0.012 \\
\hline TEM & ORNL Mo & LCAC Moly & L8 & - & Irradiation & - & - & 0.186 & 2.987 & 0.012 \\
\hline TEM & ORNL Mo & LCAC Moly & L9 & - & Irradiation & - & - & 0.180 & 2.985 & 0.012 \\
\hline TEM & ORNL Mo & LCAC Moly & L10 & - & Irradiation & - & - & 0.191 & 2.994 & 0.012 \\
\hline TEM & ORNL Mo & LCAC Moly & L11 & - & Irradiation & - & - & 0.175 & 2.984 & 0.012 \\
\hline TEM & ORNL Mo & LCAC Moly & L12 & - & Irradiation & - & - & 0.178 & 2.983 & 0.012 \\
\hline TEM & ORNL Mo & LCAC Moly & L13 & - & Irradiation & - & - & 0.181 & 2.992 & 0.012 \\
\hline TEM & ORNL Mo & LCAC Moly & L14 & - & Irradiation & - & - & 0.189 & 2.977 & 0.012 \\
\hline TEM & ORNL Mo & LCAC Moly & L15 & - & Irradiation & - & - & 0.177 & 2.990 & 0.012 \\
\hline TEM & ORNL Mo & LCAC Moly & L16 & - & Irradiation & - & - & 0.168 & 2.982 & 0.012 \\
\hline TEM & ORNL Mo & LCAC Moly & L17 & - & Irradiation & - & - & 0.180 & 2.984 & 0.012 \\
\hline TEM & ORNL Mo & LCAC Moly & L18 & - & Irradiation & - & - & 0.171 & 2.982 & 0.012 \\
\hline TEM & ORNL Mo & LCAC Moly & L19 & - & Irradiation & - & - & 0.172 & 2.988 & 0.012 \\
\hline TEM & ORNL Mo & LCAC Moly & L20 & - & Irradiation & - & - & 0.178 & 2.984 & 0.012 \\
\hline TEM & ORNL Mo & LCAC Moly & $\bar{L} 21$ & - & Control & - & - & 0.178 & 2.984 & 0.012 \\
\hline TEM & ORNL Mo & LCAC Moly & L22 & - & Control & - & - & 0.162 & 2.984 & 0.012 \\
\hline TEM & ORNL Mo & LCAC Moly & L23 & - & Control & - & - & 0.181 & 2.988 & 0.012 \\
\hline TEM & ORNL Mo & LCAC Moly & L24 & - & Control & - & - & 0.176 & 2.972 & 0.012 \\
\hline TEM & ORNL Mo & LCAC Moly & L25 & - & Control & - & - & 0.185 & 2.981 & 0.012 \\
\hline TEM & ORNL Mo & LCAC Moly & L26 & - & Control & - & - & 0.177 & 2.985 & 0.012 \\
\hline TEM & ORNL Mo & LCAC Moly & L27 & - & Control & - & - & 0.183 & 2.978 & 0.012 \\
\hline TEM & ORNL Mo & LCAC Moly & L28 & - & Control & - & - & 0.172 & 2.988 & 0.012 \\
\hline TEM & ORNL Mo & LCAC Moly & L29 & - & Control & - & - & 0.183 & 2.979 & 0.012 \\
\hline TEM & ORNL Mo & LCAC Moly & L30 & - & Control & - & - & 0.180 & 2.978 & 0.012 \\
\hline TEM & ORNL Mo & LCAC Moly & L31 & - & Control & - & - & 0.174 & 2.986 & 0.012 \\
\hline TEM & ORNL Mo & LCAC Moly & L32 & - & Control & - & - & 0.181 & 2.979 & 0.012 \\
\hline
\end{tabular}




\begin{tabular}{|c|c|c|c|c|c|c|c|c|c|c|}
\hline \multirow{2}{*}{ Type } & \multirow{2}{*}{$\begin{array}{l}\text { Material } \\
\text { Category }\end{array}$} & \multirow{2}{*}{ Material } & \multirow{2}{*}{ ID } & \multirow{2}{*}{$\begin{array}{c}\text { Alternate } \\
\text { ID }\end{array}$} & \multirow{2}{*}{ Use } & \multicolumn{4}{|c|}{ Dimensions $(\mathrm{mm})$} & \multirow{2}{*}{$\begin{array}{c}\text { Mass } \\
(\mathrm{g})\end{array}$} \\
\hline & & & & & & $\mathrm{L}$ & W & $\mathrm{T}$ & Dia. & \\
\hline TEM & ORNL Mo & Mo-alloy 6 & M1 & - & Irradiation & - & - & 0.144 & 2.974 & 0.012 \\
\hline TEM & ORNL Mo & Mo-alloy 6 & M2 & - & Irradiation & - & - & 0.175 & 2.976 & 0.012 \\
\hline TEM & ORNL Mo & Mo-alloy 6 & M3 & - & Irradiation & - & - & 0.167 & 2.984 & 0.012 \\
\hline TEM & ORNL Mo & Mo-alloy 6 & M4 & - & Irradiation & - & - & 0.184 & 2.971 & 0.012 \\
\hline TEM & ORNL Mo & Mo-alloy 6 & M5 & - & Irradiation & - & - & 0.172 & 2.980 & 0.012 \\
\hline TEM & ORNL Mo & Mo-alloy 6 & M6 & - & Irradiation & - & - & 0.178 & 2.975 & 0.012 \\
\hline TEM & ORNL Mo & Mo-alloy 6 & M7 & - & Irradiation & - & - & 0.174 & 2.977 & 0.012 \\
\hline TEM & ORNL Mo & Mo-alloy 6 & M8 & - & Irradiation & - & - & 0.173 & 2.971 & 0.012 \\
\hline TEM & ORNL Mo & Mo-alloy 6 & M9 & - & Irradiation & - & - & 0.174 & 2.972 & 0.012 \\
\hline TEM & ORNL Mo & Mo-alloy 6 & M10 & - & Irradiation & - & - & 0.184 & 2.971 & 0.012 \\
\hline TEM & ORNL Mo & Mo-alloy 6 & M11 & - & Irradiation & - & - & 0.171 & 2.961 & 0.012 \\
\hline TEM & ORNL Mo & Mo-alloy 6 & M12 & - & Irradiation & - & - & 0.171 & 2.992 & 0.012 \\
\hline TEM & ORNL Mo & Mo-alloy 6 & M13 & - & Irradiation & - & - & 0.171 & 2.971 & 0.012 \\
\hline TEM & ORNL Mo & Mo-alloy 6 & M14 & - & Irradiation & - & - & 0.175 & 2.971 & 0.012 \\
\hline TEM & ORNL Mo & Mo-alloy 6 & M15 & - & Irradiation & - & - & 0.177 & 2.974 & 0.012 \\
\hline TEM & ORNL Mo & Mo-alloy 6 & M16 & - & Irradiation & - & - & 0.172 & 2.975 & 0.012 \\
\hline TEM & ORNL Mo & Mo-alloy 6 & M17 & - & Irradiation & - & - & 0.175 & 2.973 & 0.012 \\
\hline TEM & ORNL Mo & Mo-alloy 6 & M18 & - & Irradiation & - & - & 0.165 & 2.976 & 0.012 \\
\hline TEM & ORNL Mo & Mo-alloy 6 & M19 & - & Irradiation & - & - & 0.174 & 2.974 & 0.012 \\
\hline TEM & ORNL Mo & Mo-alloy 6 & M20 & - & Irradiation & - & - & 0.182 & 2.972 & 0.012 \\
\hline TEM & ORNL Mo & Mo-alloy 6 & M21 & - & Control & - & - & 0.178 & 2.977 & 0.012 \\
\hline TEM & ORNL Mo & Mo-alloy 6 & M22 & - & Control & - & - & 0.172 & 2.964 & 0.012 \\
\hline TEM & ORNL Mo & Mo-alloy 6 & M23 & - & Control & - & - & 0.172 & 2.976 & 0.012 \\
\hline TEM & ORNL Mo & Mo-alloy 6 & M24 & - & Control & - & - & 0.175 & 2.977 & 0.012 \\
\hline TEM & ORNL Mo & Mo-alloy 6 & M25 & - & Control & - & - & 0.175 & 2.973 & 0.012 \\
\hline TEM & ORNL Mo & Mo-alloy 6 & M26 & - & Control & - & - & 0.178 & 2.980 & 0.012 \\
\hline TEM & ORNL Mo & Mo-alloy 6 & M27 & - & Control & - & - & 0.174 & 2.975 & 0.012 \\
\hline TEM & ORNL Mo & Mo-alloy 6 & M28 & - & Control & - & - & 0.172 & 2.971 & 0.012 \\
\hline TEM & ORNL Mo & Mo-alloy 6 & M29 & - & Control & - & - & 0.177 & 2.974 & 0.012 \\
\hline TEM & ORNL Mo & Mo-alloy 6 & M30 & - & Control & - & - & 0.177 & 2.976 & 0.012 \\
\hline TEM & ORNL Mo & Mo-alloy 6 & M31 & - & Control & - & - & 0.178 & 2.975 & 0.012 \\
\hline TEM & ORNL Mo & Mo-alloy 6 & M32 & - & Control & - & - & 0.178 & 2.974 & 0.012 \\
\hline
\end{tabular}




\begin{tabular}{|c|c|c|c|c|c|c|c|c|c|c|}
\hline \multirow{2}{*}{ Type } & \multirow{2}{*}{$\begin{array}{l}\text { Material } \\
\text { Category }\end{array}$} & \multirow{2}{*}{ Material } & \multirow{2}{*}{ ID } & \multirow{2}{*}{$\begin{array}{c}\text { Alternate } \\
\text { ID }\end{array}$} & \multirow{2}{*}{ Use } & \multicolumn{4}{|c|}{ Dimensions $(\mathrm{mm})$} & \multirow{2}{*}{$\begin{array}{l}\text { Mass } \\
\text { (g) }\end{array}$} \\
\hline & & & & & & $\mathrm{L}$ & W & $\mathrm{T}$ & Dia. & \\
\hline BB & ORNL Mo & LCAC Moly & LB1 & - & Irradiation & 25.110 & 2.508 & 2.009 & - & 1.283 \\
\hline $\mathrm{BB}$ & ORNL Mo & LCAC Moly & LB2 & - & Irradiation & 25.095 & 2.504 & 2.038 & - & 1.284 \\
\hline $\mathrm{BB}$ & ORNL Mo & LCAC Moly & LB3 & - & Irradiation & 25.118 & 2.508 & 2.016 & - & 1.281 \\
\hline BB & ORNL Mo & LCAC Moly & LB4 & - & Irradiation & 25.136 & 2.506 & 2.007 & - & 1.283 \\
\hline BB & ORNL Mo & LCAC Moly & LB5 & - & Irradiation & 25.089 & 2.504 & 2.006 & - & 1.282 \\
\hline BB & ORNL Mo & LCAC Moly & LB6 & - & Irradiation & 25.099 & 2.513 & 2.006 & - & 1.278 \\
\hline BB & ORNL Mo & LCAC Moly & LB7 & - & Control & 25.175 & 2.506 & 2.011 & - & 1.283 \\
\hline $\mathrm{BB}$ & ORNL Mo & LCAC Moly & LB8 & - & Control & 25.114 & 2.511 & 2.008 & - & 1.280 \\
\hline $\mathrm{BB}$ & ORNL Mo & LCAC Moly & LB9 & - & Control & 25.108 & 2.501 & 2.008 & - & 1.280 \\
\hline $\mathrm{BB}$ & ORNL Mo & LCAC Moly & LB10 & - & Control & 25.125 & 2.502 & 2.015 & - & 1.281 \\
\hline BB & ORNL Mo & LCAC Moly & LB11 & - & Control & 25.102 & 2.505 & 2.012 & - & 1.280 \\
\hline $\mathrm{BB}$ & ORNL Mo & LCAC Moly & LB12 & - & Control & 25.079 & 2.508 & 2.006 & - & 1.271 \\
\hline BB & ORNL Mo & Mo-alloy 6 & MB1 & - & Irradiation & 25.155 & 2.499 & 2.000 & - & 1.269 \\
\hline $\mathrm{BB}$ & ORNL Mo & Mo-alloy 6 & MB2 & - & Irradiation & 25.135 & 2.502 & 2.013 & - & 1.280 \\
\hline $\mathrm{BB}$ & ORNL Mo & Mo-alloy 6 & MB3 & - & Irradiation & 25.144 & 2.498 & 2.003 & - & 1.278 \\
\hline BB & ORNL Mo & Mo-alloy 6 & MB4 & - & Irradiation & 25.137 & 2.499 & 2.008 & - & 1.272 \\
\hline BB & ORNL Mo & Mo-alloy 6 & MB5 & - & Irradiation & 25.155 & 2.501 & 2.009 & - & 1.284 \\
\hline BB & ORNL Mo & Mo-alloy 6 & MB6 & - & Irradiation & 25.154 & 2.502 & 2.005 & - & 1.275 \\
\hline $\mathrm{BB}$ & ORNL Mo & Mo-alloy 6 & MB7 & - & Control & 25.170 & 2.506 & 2.005 & - & 1.281 \\
\hline BB & ORNL Mo & Mo-alloy 6 & MB8 & - & Control & 25.147 & 2.503 & 2.005 & - & 1.280 \\
\hline $\mathrm{BB}$ & ORNL Mo & Mo-alloy 6 & MB9 & - & Control & 25.151 & 2.506 & 2.000 & - & 1.270 \\
\hline $\mathrm{BB}$ & ORNL Mo & Mo-alloy 6 & MB10 & - & Control & 25.142 & 2.504 & 2.010 & - & 1.278 \\
\hline $\mathrm{BB}$ & ORNL Mo & Mo-alloy 6 & MB11 & - & Control & 25.150 & 2.498 & 2.018 & - & 1.275 \\
\hline BB & ORNL Mo & Mo-alloy 6 & MB12 & - & Control & 25.145 & 2.499 & 2.009 & - & 1.271 \\
\hline
\end{tabular}




\begin{tabular}{|c|c|c|c|c|c|c|c|c|c|c|}
\hline \multirow{2}{*}{ Type } & \multirow{2}{*}{$\begin{array}{l}\text { Material } \\
\text { Category }\end{array}$} & \multirow{2}{*}{ Material } & \multirow{2}{*}{ ID } & \multirow{2}{*}{$\begin{array}{c}\text { Alternate } \\
\text { ID }\end{array}$} & \multirow{2}{*}{ Use } & \multicolumn{4}{|c|}{ Dimensions (mm) } & \multirow{2}{*}{$\begin{array}{c}\text { Mass } \\
(\mathrm{g})\end{array}$} \\
\hline & & & & & & L & W & $\mathrm{T}$ & Dia. & \\
\hline CYL & ORNL Mo & LCAC Moly & LC1 & - & Irradiation & 10.018 & - & - & 2.985 & 0.713 \\
\hline CYL & ORNL Mo & LCAC Moly & LC2 & - & Control & 9.991 & - & - & 2.971 & 0.704 \\
\hline$\overline{C Y L}$ & ORNL Mo & LCAC Moly & LC3 & - & Control & 9.988 & - & - & 2.985 & 0.710 \\
\hline
\end{tabular}




\begin{tabular}{|c|c|c|c|c|c|c|c|c|c|c|}
\hline \multirow{2}{*}{ Type } & \multirow{2}{*}{$\begin{array}{l}\text { Material } \\
\text { Cateqory }\end{array}$} & \multirow{2}{*}{ Material } & \multirow{2}{*}{ ID } & \multirow{2}{*}{$\begin{array}{l}\text { Alternate } \\
\text { ID }\end{array}$} & \multirow{2}{*}{ Use } & \multicolumn{4}{|c|}{ Dimensions (mm) } & \multirow{2}{*}{$\begin{array}{c}\text { Mass } \\
(\mathrm{g})\end{array}$} \\
\hline & & & & & & $\mathrm{L}$ & W & $\mathrm{T}$ & Dia. & \\
\hline TDD & ORNL Mo & LCAC Moly & LA1 & - & Irradiation & - & - & 2.023 & 7.964 & 1.020 \\
\hline TDD & ORNL Mo & LCAC Moly & LA2 & - & Irradiation & - & - & 2.016 & 7.980 & 1.018 \\
\hline TDD & ORNL Mo & LCAC Moly & LA3 & - & Irradiation & - & - & 2.021 & 7.967 & 1.021 \\
\hline TDD & ORNL Mo & LCAC Moly & LA4 & - & Irradiation & - & - & 1.989 & 7.967 & 1.007 \\
\hline TDD & ORNL Mo & LCAC Moly & LA5 & - & Irradiation & - & - & 2.032 & 7.965 & 1.014 \\
\hline TDD & ORNL Mo & LCAC Moly & LA6 & - & Control & - & - & 2.008 & 7.964 & 1.016 \\
\hline TDD & ORNL Mo & LCAC Moly & LA7 & - & Control & - & - & 2.028 & 7.944 & 1.020 \\
\hline TDD & ORNL Mo & LCAC Moly & LA8 & - & Control & - & - & 2.007 & 7.978 & 1.019 \\
\hline TDD & ORNL Mo & LCAC Moly & LA9 & - & Control & - & - & 2.033 & 7.965 & 1.021 \\
\hline TDD & ORNL Mo & LCAC Moly & LA10 & - & Control & - & - & 2.020 & 7.973 & 1.018 \\
\hline TDD & ORNL Mo & LCAC Moly & LA11 & - & Control & - & - & 2.022 & 7.960 & 1.022 \\
\hline TDD & ORNL Mo & LCAC Moly & LA12 & - & Control & - & - & 2.018 & 7.956 & 1.012 \\
\hline TDD & ORNL Mo & Mo-alloy 6 & MA1 & - & Irradiation & - & - & 2.043 & 7.967 & 1.028 \\
\hline TDD & ORNL Mo & Mo-alloy 6 & MA2 & - & Irradiation & - & - & 2.006 & 7.952 & 1.008 \\
\hline TDD & ORNL Mo & Mo-alloy 6 & MA3 & - & Irradiation & - & - & 2.050 & 7.960 & 1.022 \\
\hline TDD & ORNL Mo & Mo-alloy 6 & MA4 & - & Irradiation & - & - & 2.042 & 7.965 & 1.025 \\
\hline TDD & ORNL Mo & Mo-alloy 6 & MA5 & - & Irradiation & - & - & 1.993 & 7.979 & 1.005 \\
\hline TDD & ORNL Mo & Mo-alloy 6 & MA6 & - & Control & - & - & 2.067 & 7.990 & 1.034 \\
\hline TDD & ORNL Mo & Mo-alloy 6 & MA7 & - & Control & - & - & 2.047 & 7.961 & 1.023 \\
\hline TDD & ORNL Mo & Mo-alloy 6 & MA8 & - & Control & - & - & 2.010 & 7.953 & 1.012 \\
\hline TDD & ORNL Mo & Mo-alloy 6 & MA9 & - & Control & - & - & 1.998 & 7.947 & 1.000 \\
\hline TDD & ORNL Mo & Mo-alloy 6 & MA10 & - & Control & - & - & 1.976 & 8.000 & 0.998 \\
\hline TDD & ORNL Mo & Mo-alloy 6 & MA11 & - & Control & - & - & 2.041 & 7.958 & 1.019 \\
\hline TDD & ORNL Mo & Mo-alloy 6 & MA12 & - & Control & - & - & 2.019 & 7.956 & 1.008 \\
\hline
\end{tabular}




\section{Attachment 6}

Photographs of ORNL Specimens 


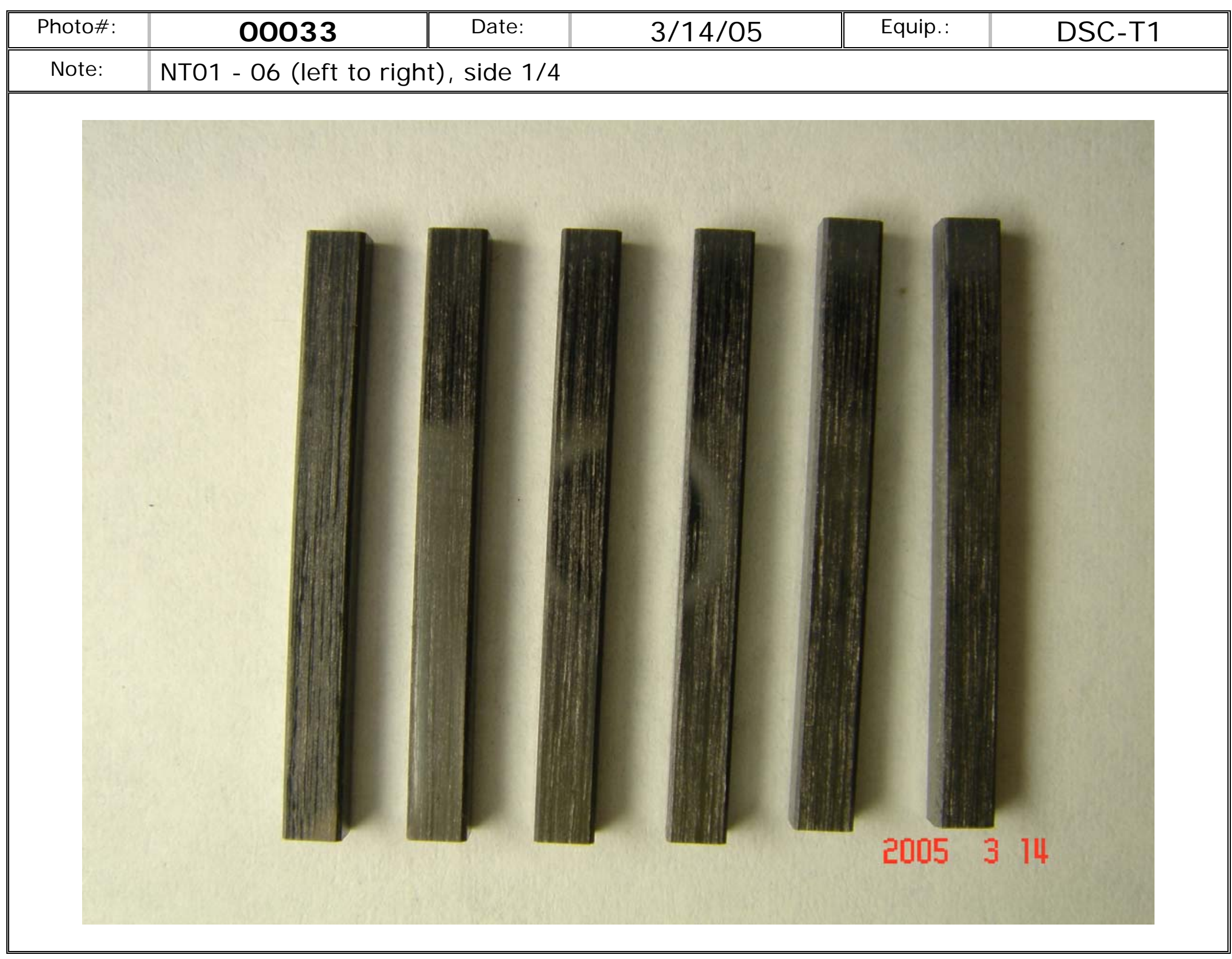




\begin{tabular}{|c|c|c|c|c|c|}
\hline Photo\#: & $\mathbf{0 0 0 3 4}$ & Date: & $3 / 14 / 05$ & Equip.: & DSC-T1 \\
\hline \hline Note: & NT01 - 06 (left to right), side 2/4 & & \\
\hline & & \\
\end{tabular}




\begin{tabular}{|c|c|c|c|c|c|}
\hline Photo\#: & $\mathbf{0 0 0 3 5}$ & Date: & $3 / 14 / 05$ & Equip.: & DSC-T1 \\
\hline \hline Note: & NT01 - 06 (left to right), side 3/4 & & \\
\hline & & & & & \\
\hline
\end{tabular}




\begin{tabular}{|c|c|c|c|c|c|}
\hline Photo\#: & $\mathbf{0 0 0 3 6}$ & Date: & $3 / 14 / 05$ & Equip.: & DSC-T1 \\
\hline \hline Note: & NT01 - 06 (left to right), side 4/4 & & \\
\hline & & & \\
\hline
\end{tabular}




\begin{tabular}{|c|c|c|c|c|c|}
\hline Photo\#: & $\mathbf{0 0 0 3 8}$ & Date: & $3 / 14 / 05$ & Equip.: & DSC-T1 \\
\hline \hline Note: & NT07 - 12 (left to right), side $1 / 4$ & & \\
\hline & & & \\
\hline
\end{tabular}




\begin{tabular}{|c|c|c|c|c|c|}
\hline Photo\#: & $\mathbf{0 0 0 3 9}$ & Date: & $3 / 14 / 05$ & Equip.: & DSC-T1 \\
\hline \hline Note: & NT07 - 12 (left to right), side 2/4 & & \\
\hline & & & & & \\
\hline
\end{tabular}




\begin{tabular}{|c|c|c|c|c|c|}
\hline Photo\#: & $\mathbf{0 0 0 4 0}$ & Date: & $3 / 14 / 05$ & Equip.: & DSC-T1 \\
\hline \hline Note: & NT07 - 12 (left to right), side 3/4 & & \\
\hline & & & \\
\hline
\end{tabular}




\begin{tabular}{|c|c|c|c|c|c|}
\hline Photo\#: & 00041 & Date: & $3 / 14 / 05$ & Equip.: & DSC-T1 \\
\hline \hline Note: & NT07 - 12 (left to right), side 4/4 & & \\
\hline & & & \\
\hline
\end{tabular}




\begin{tabular}{|c|c|c|c|c|c|}
\hline Photo\#: & $\mathbf{0 0 0 4 3}$ & Date: & $3 / 14 / 05$ & Equip.: & DSC-T1 \\
\hline \hline Note: & NT21 - 22 (left to right), side $1 / 3$ & & \\
\hline \hline & & & \\
\hline
\end{tabular}




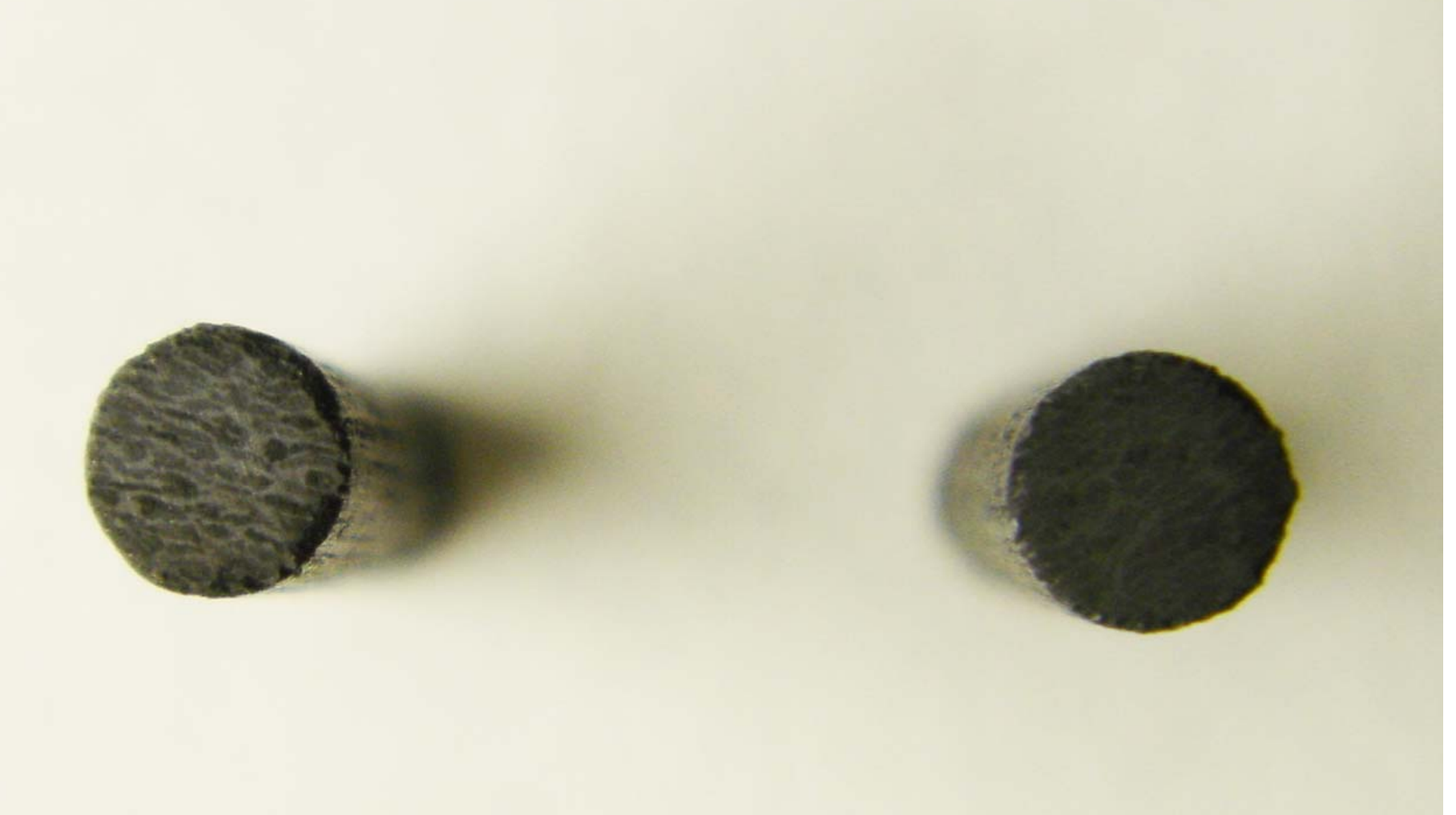





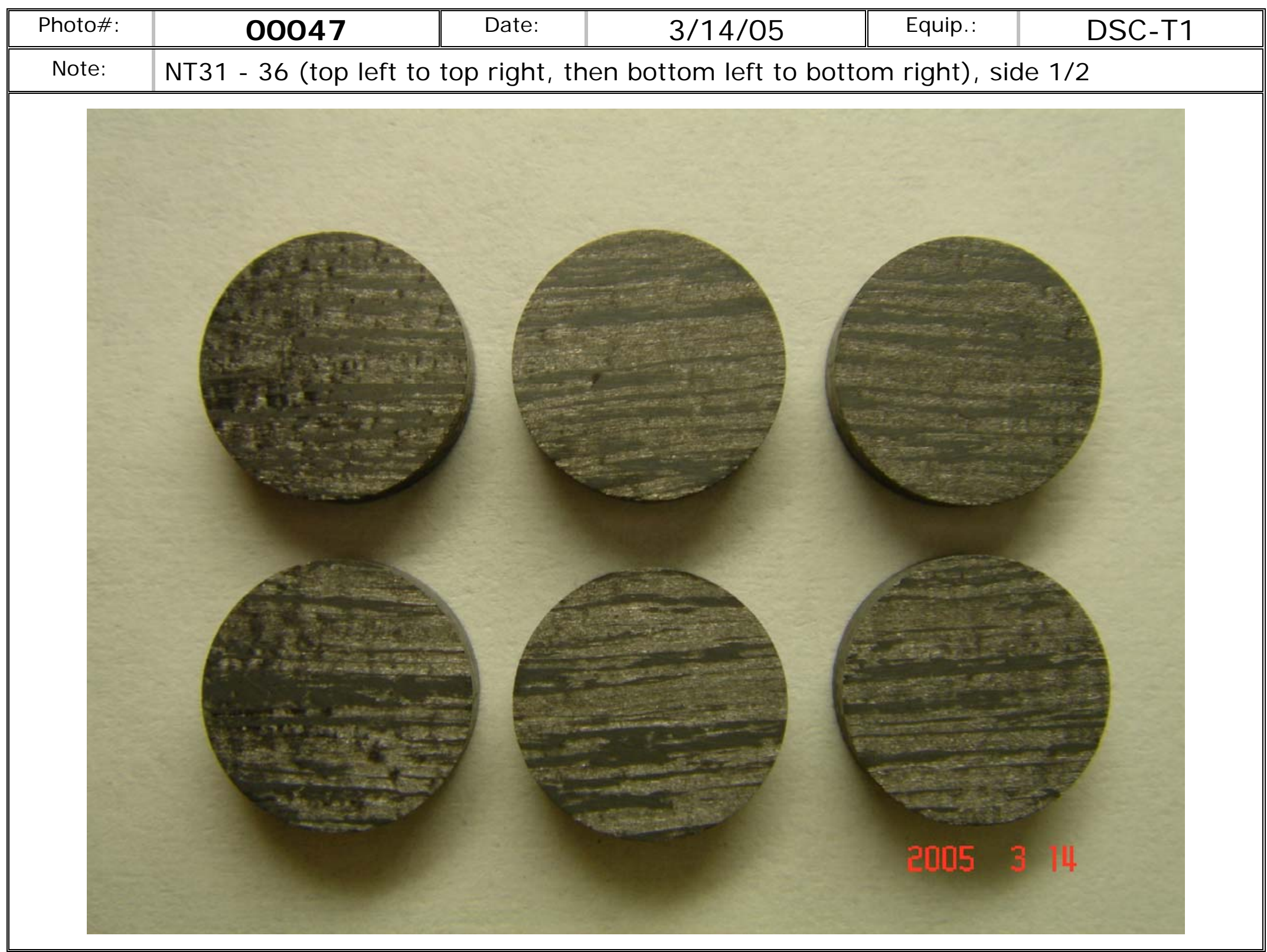




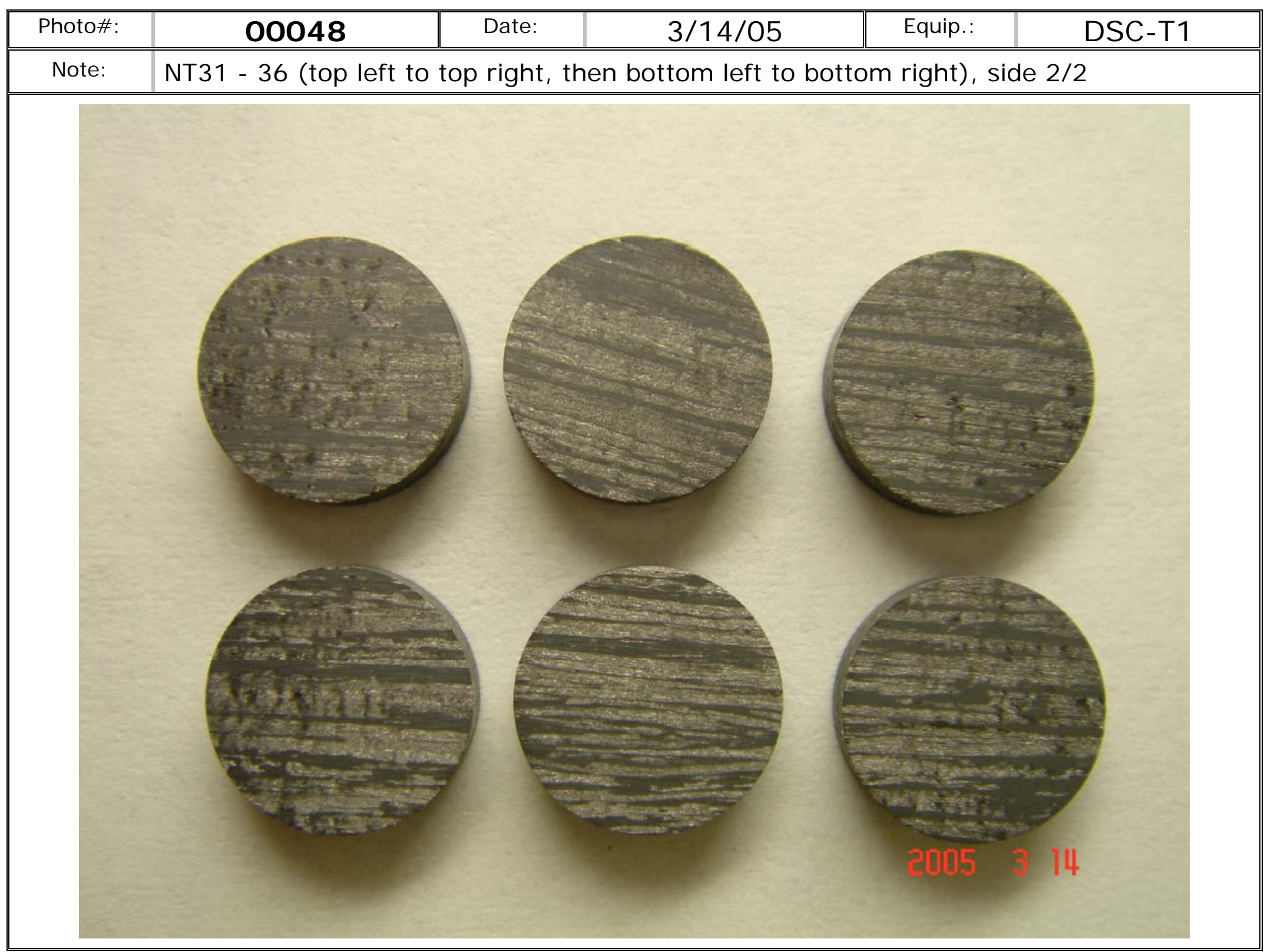




\begin{tabular}{|c|c|c|c|c|c|}
\hline Photo\#: & $\mathbf{0 0 0 5 0}$ & Date: & 3/14/05 & Equip.: & DSC-T1 \\
\hline \hline Note: & LP31 - 36 (top left to top right, then bottom left to bottom right), side 1/2 \\
\hline \hline
\end{tabular}




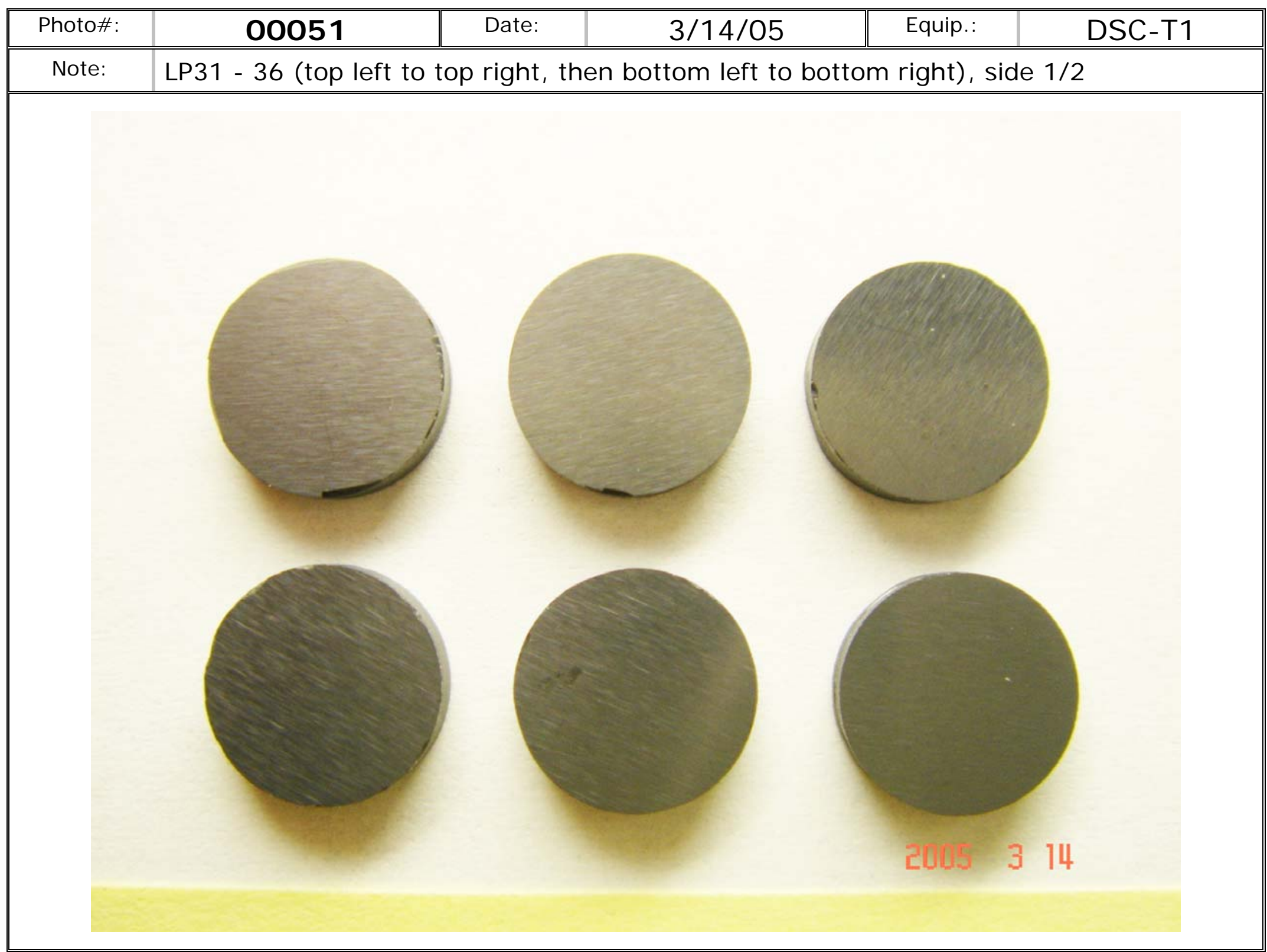




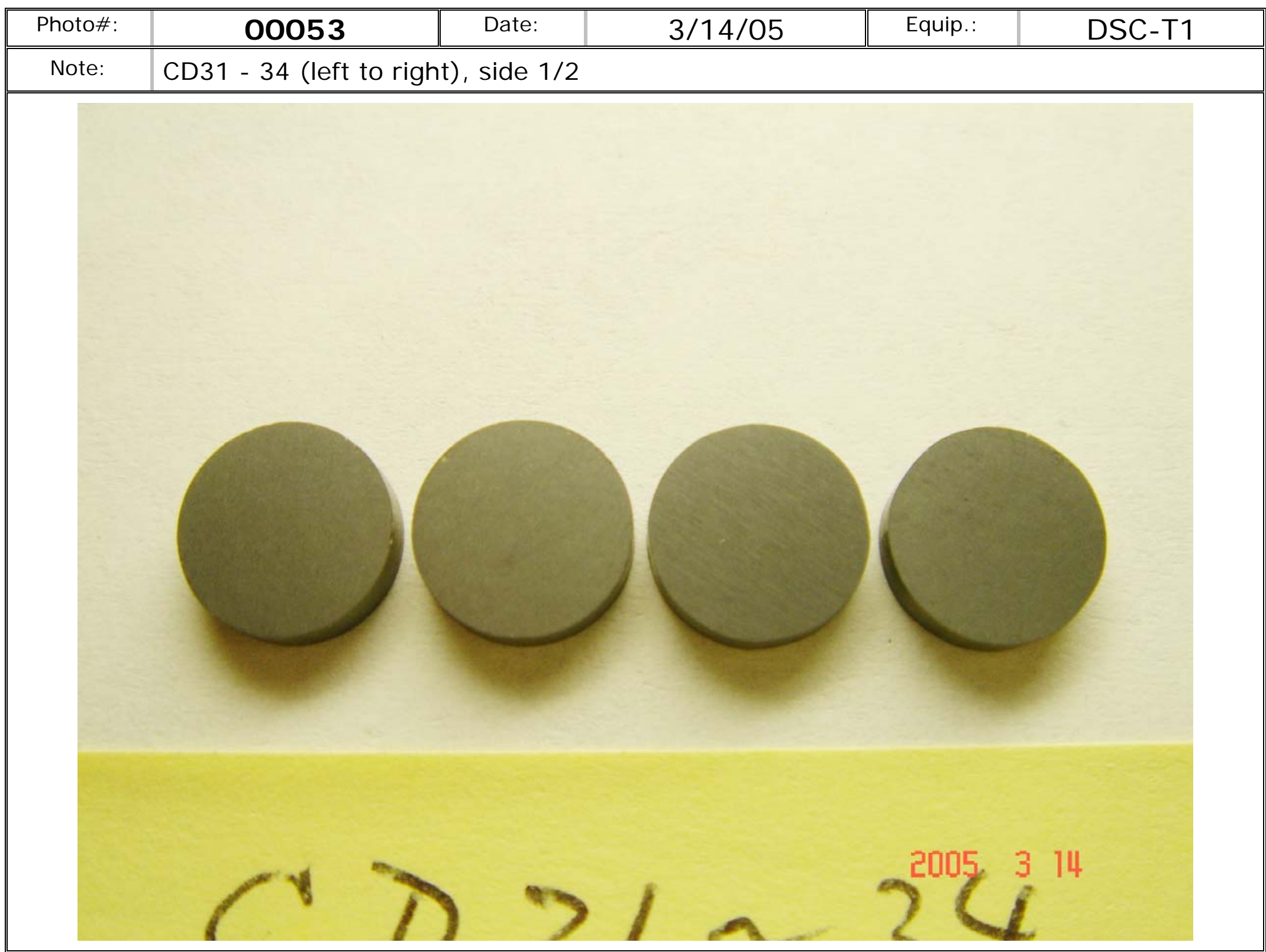


File: A6_Futurix-MI_ORNL_Specimen_Photos

Printed 5/ 9/ 2005 Page 17 / 76

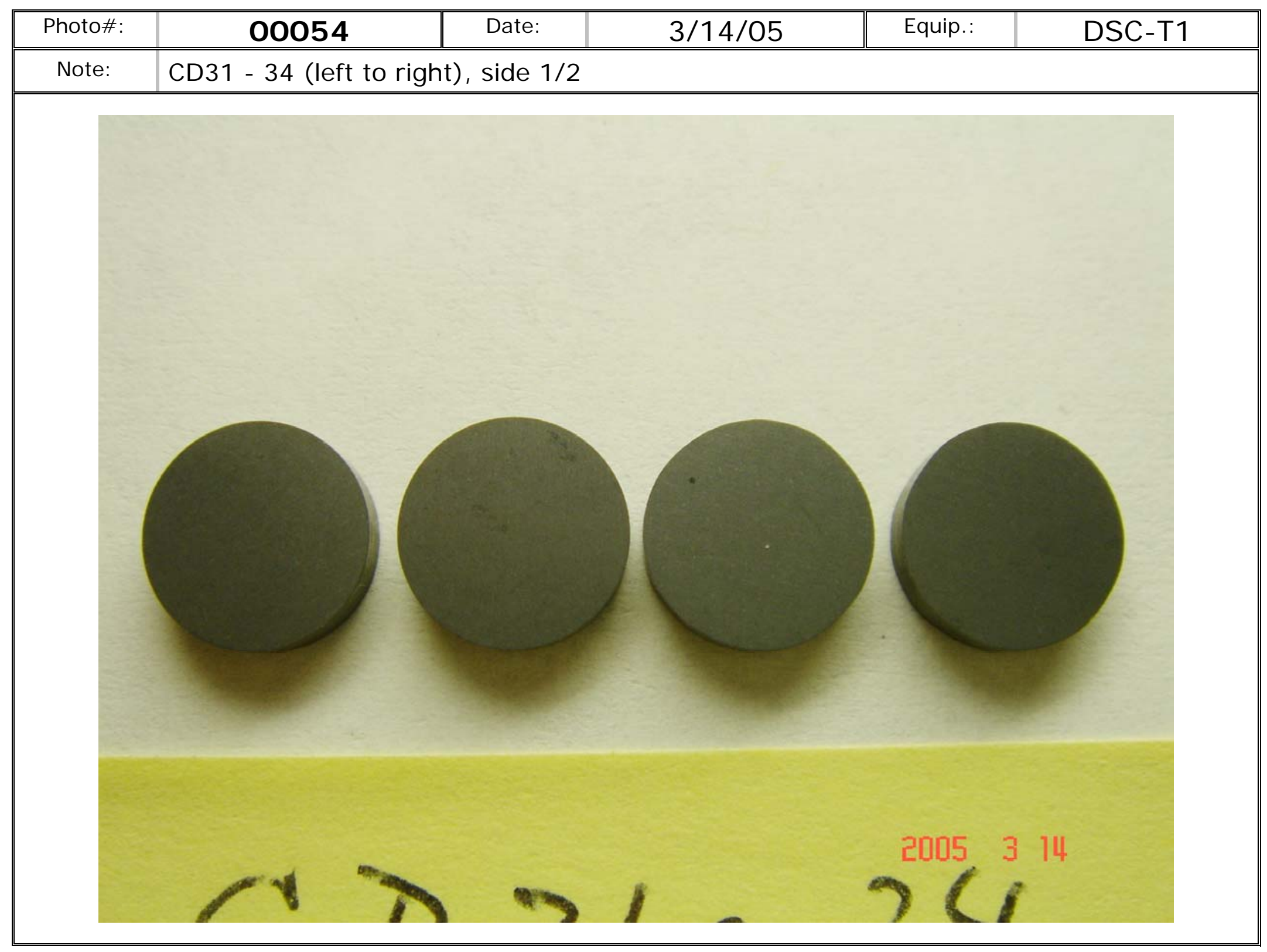

F17 


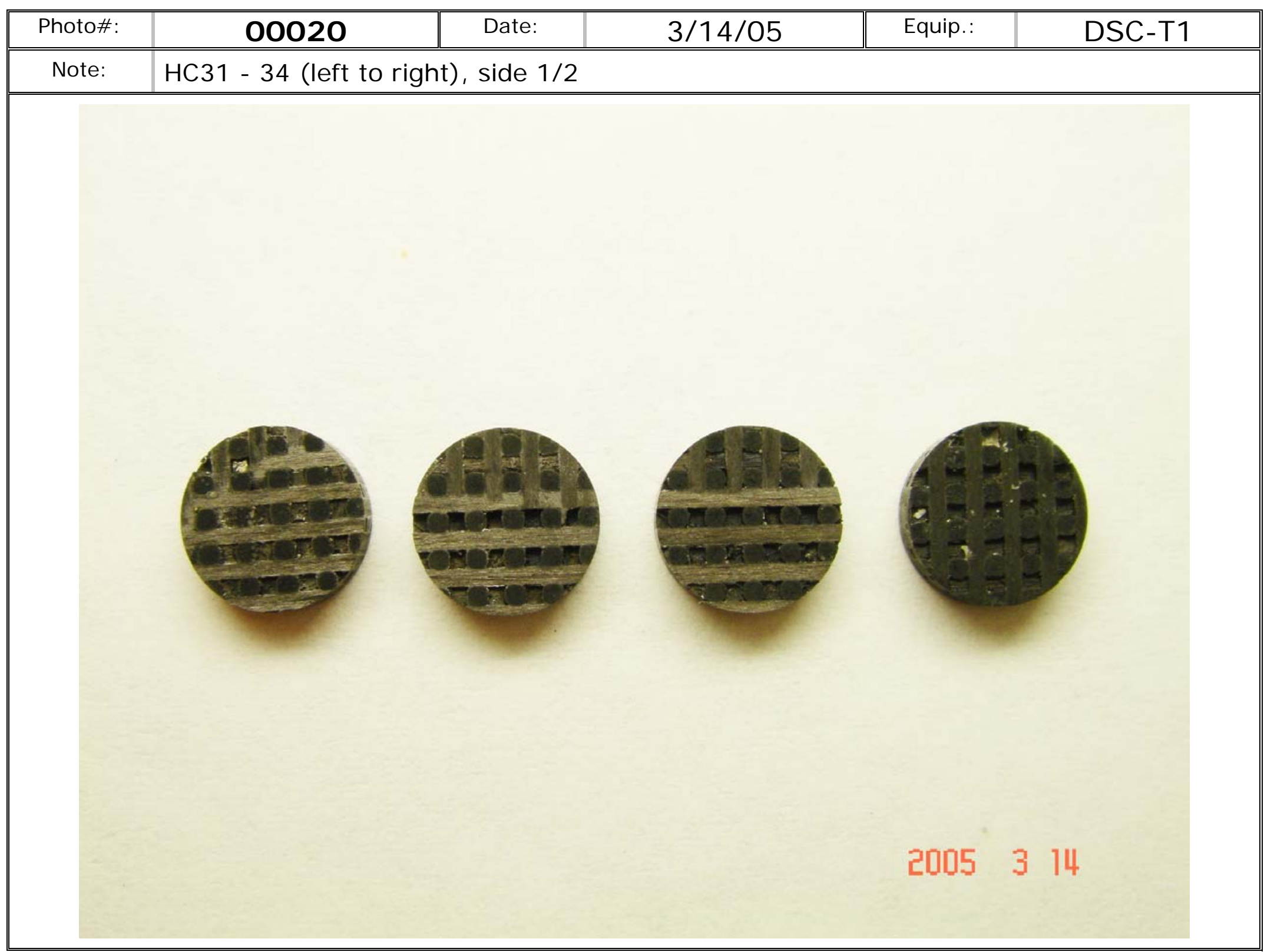




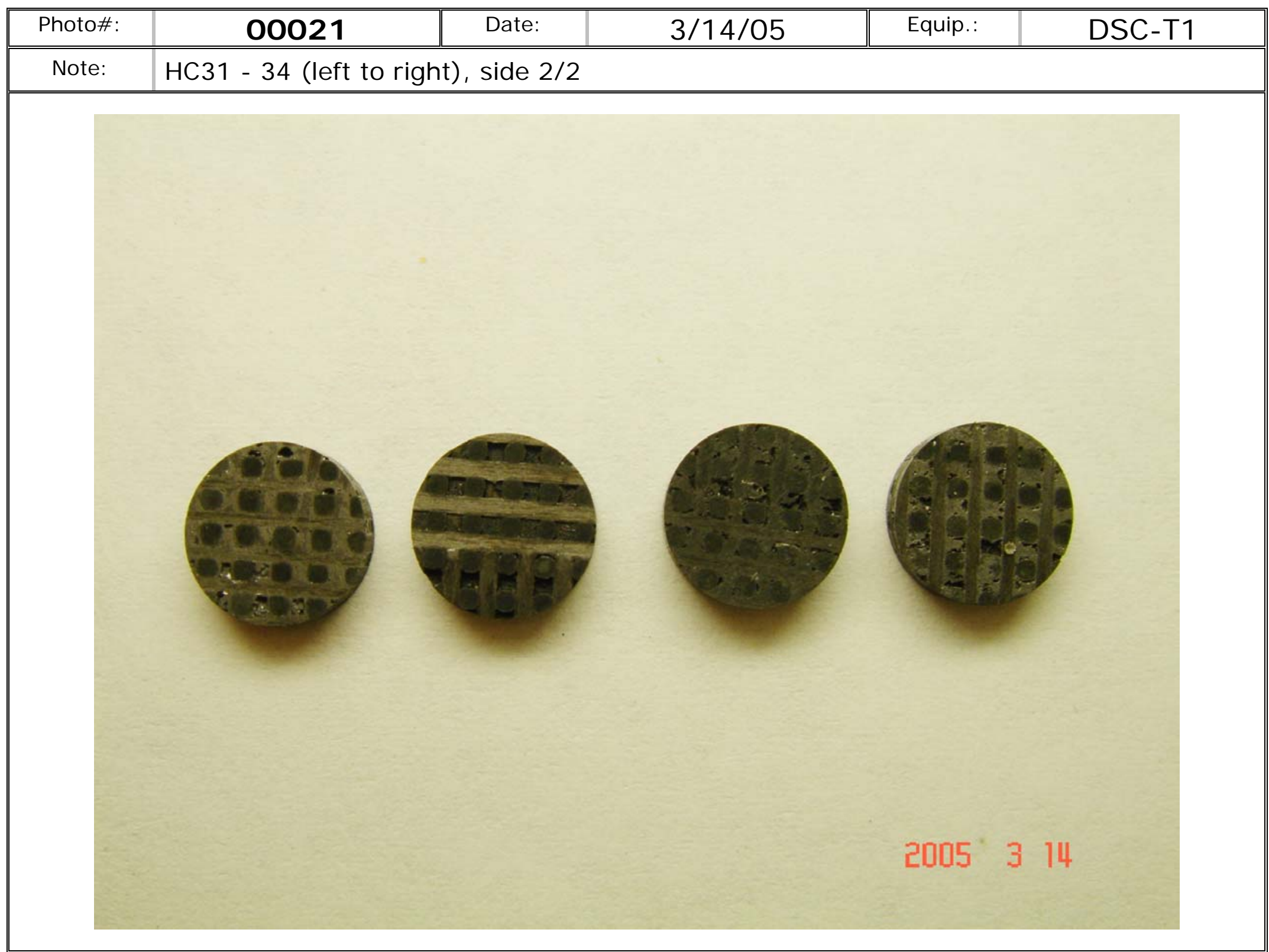




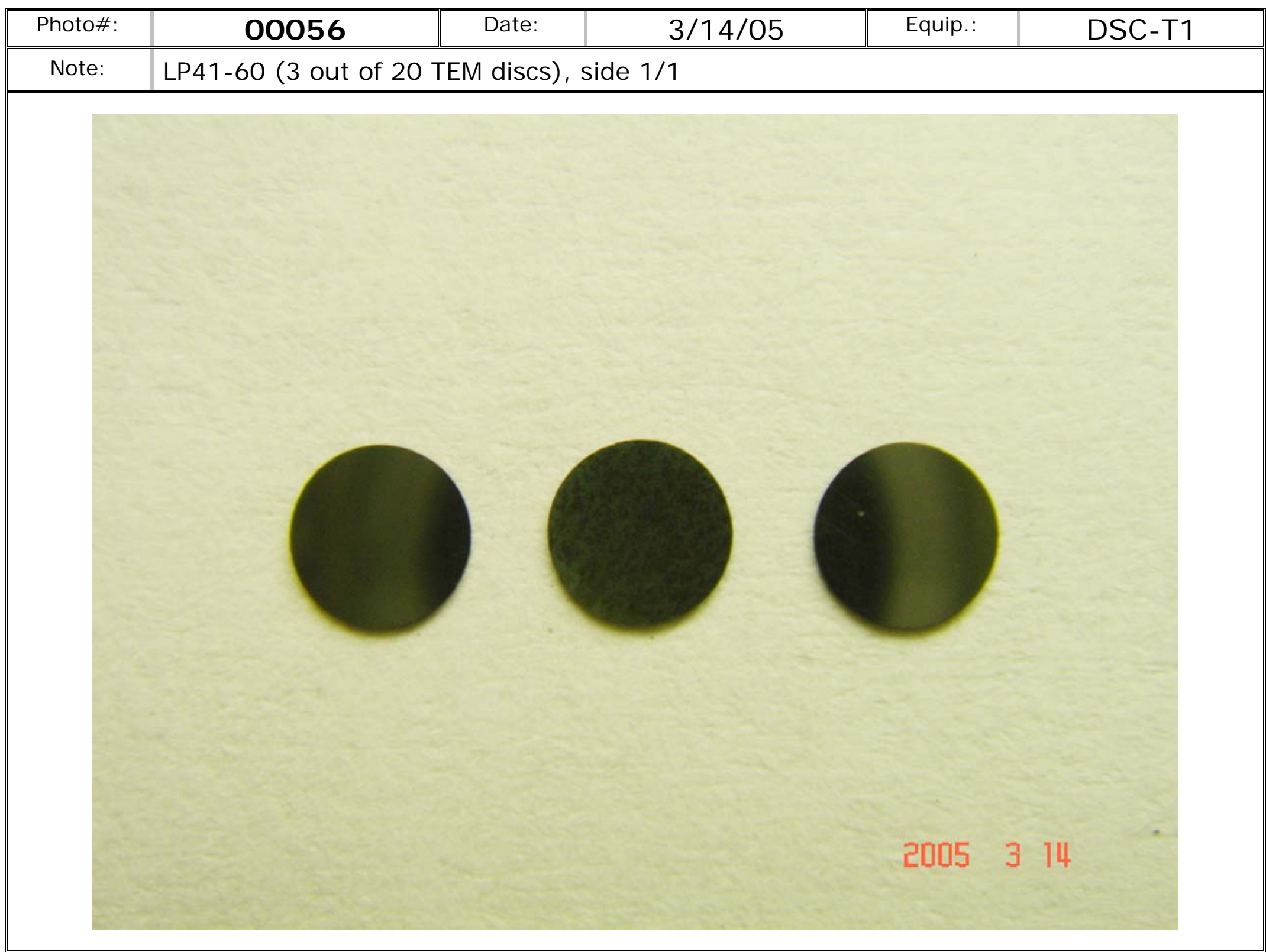




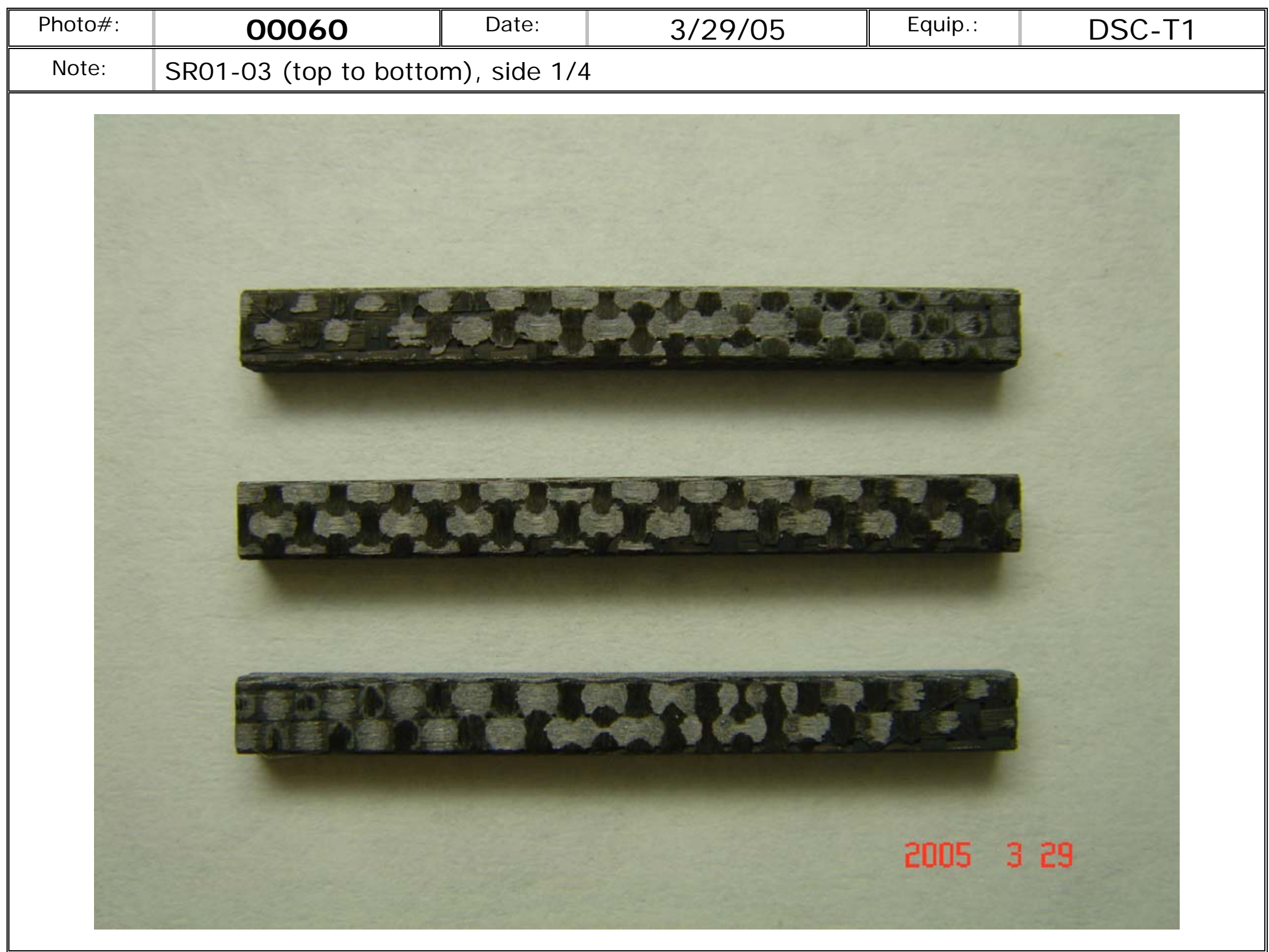




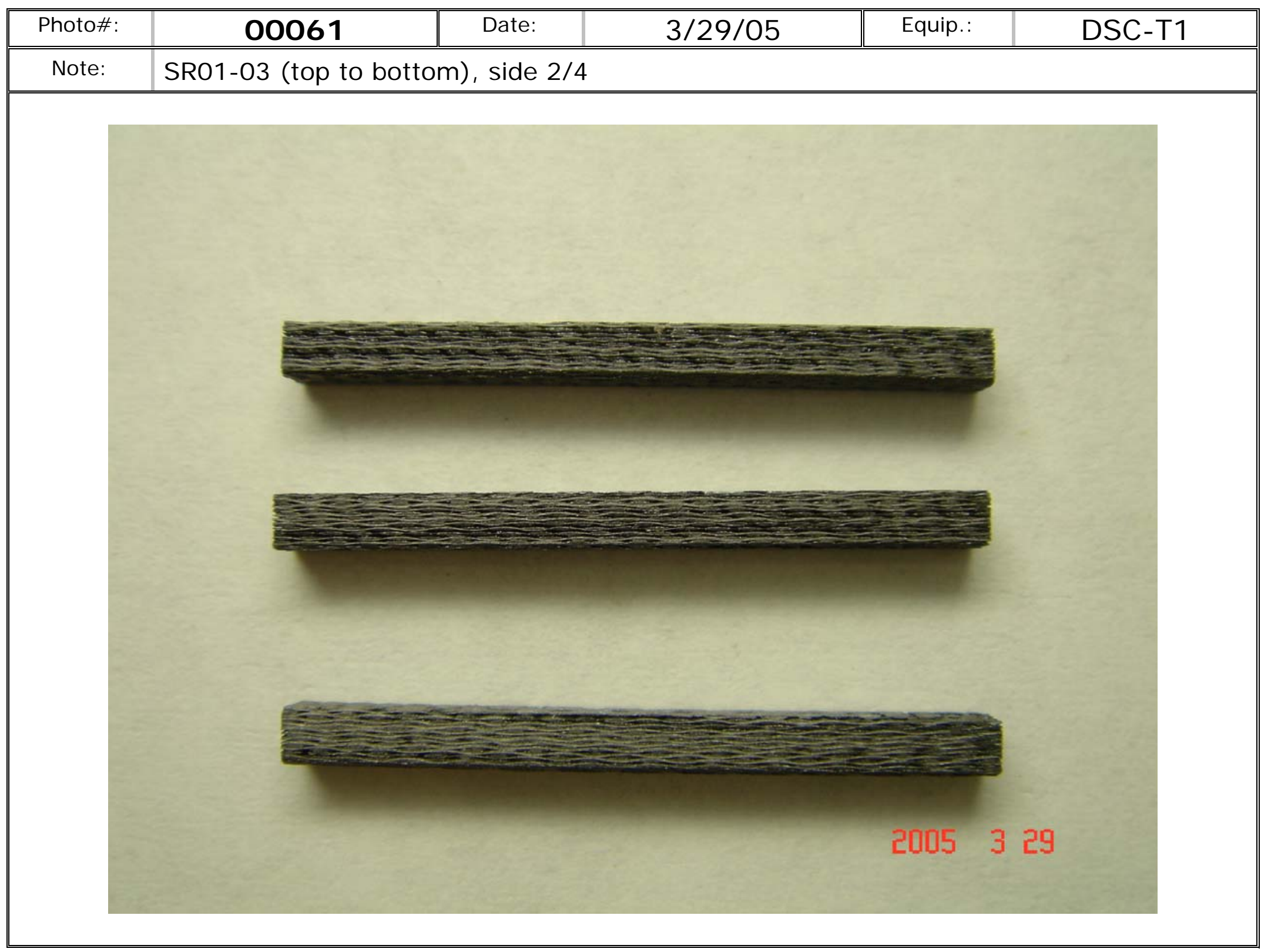




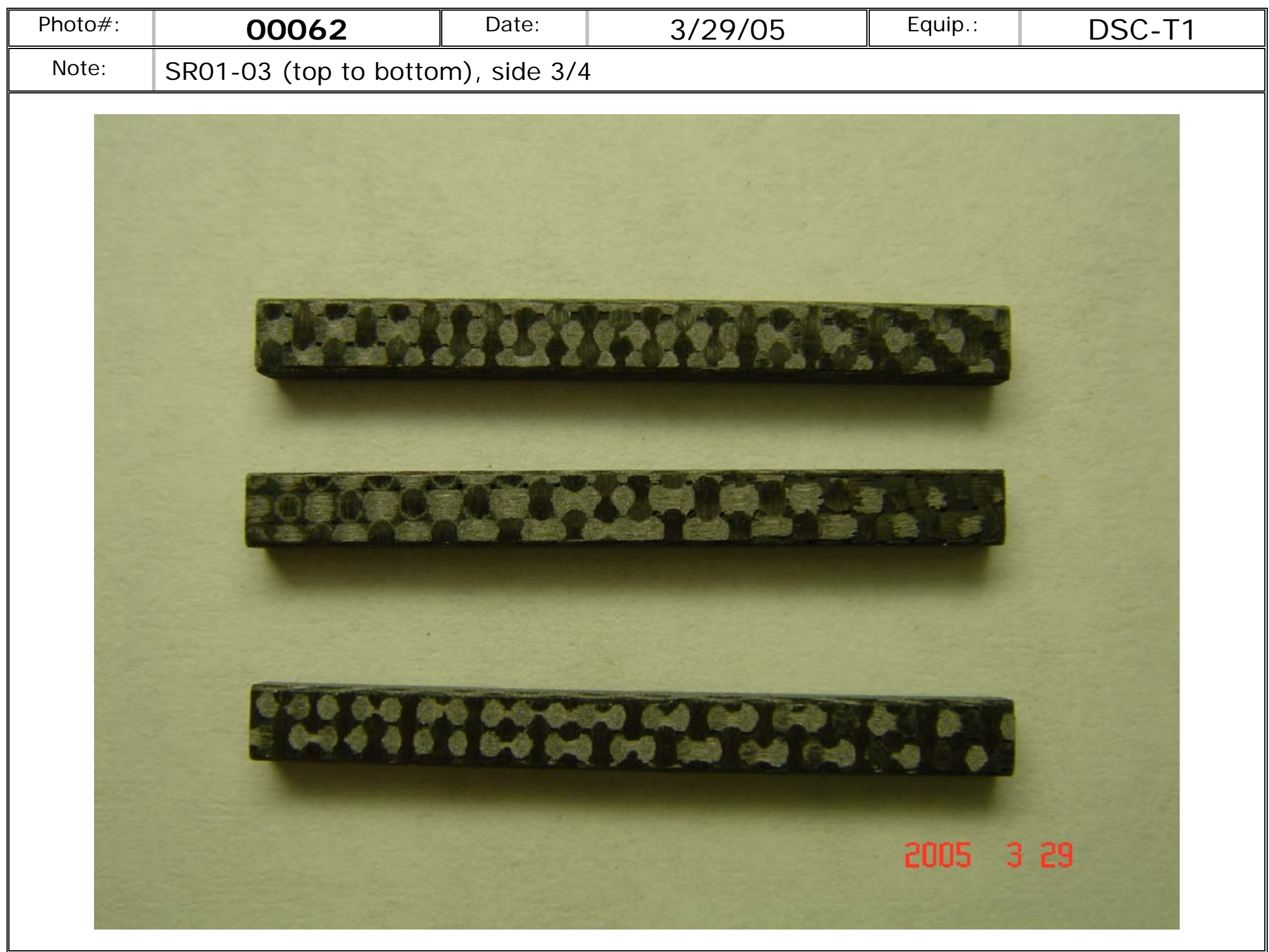




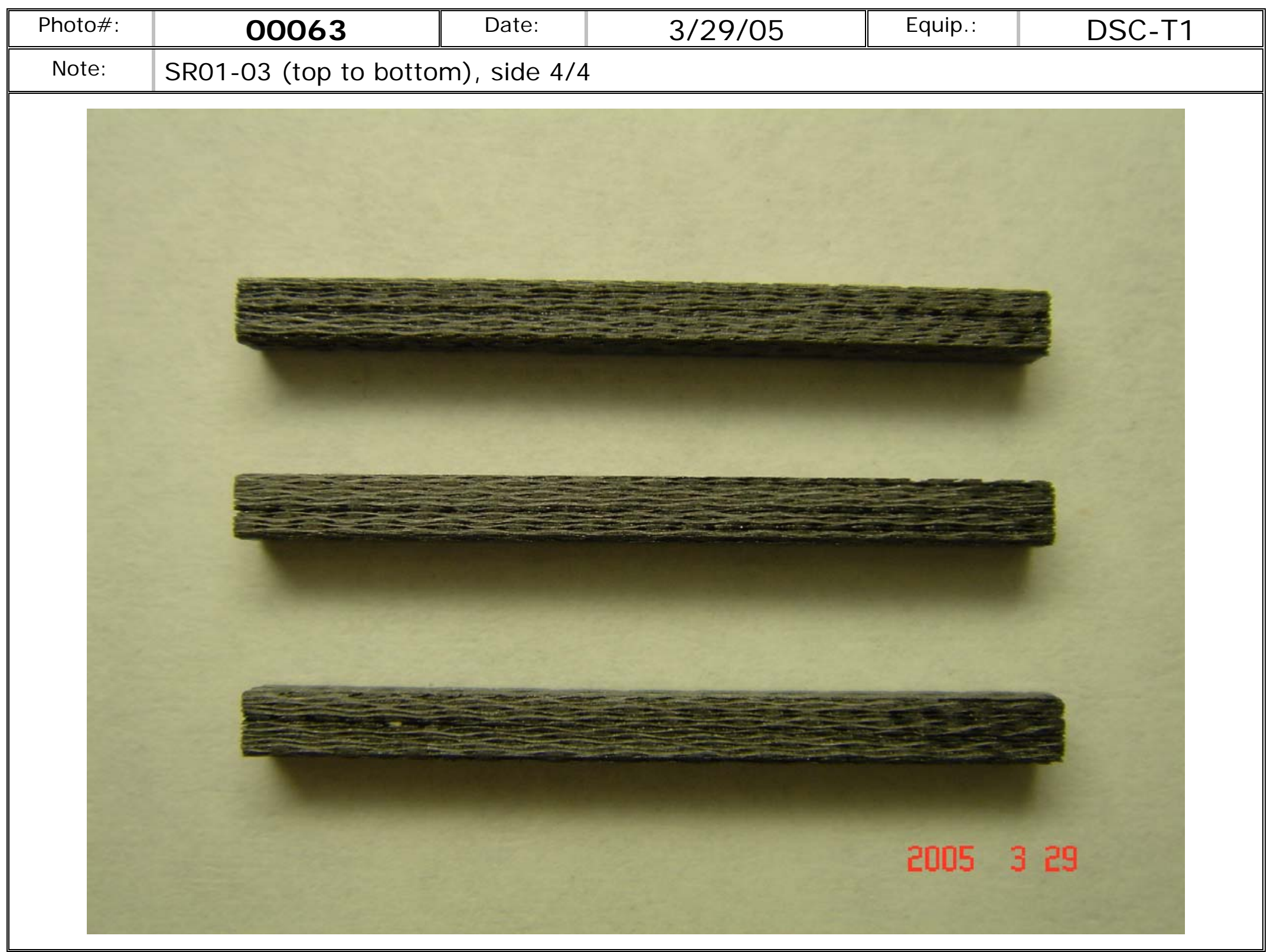




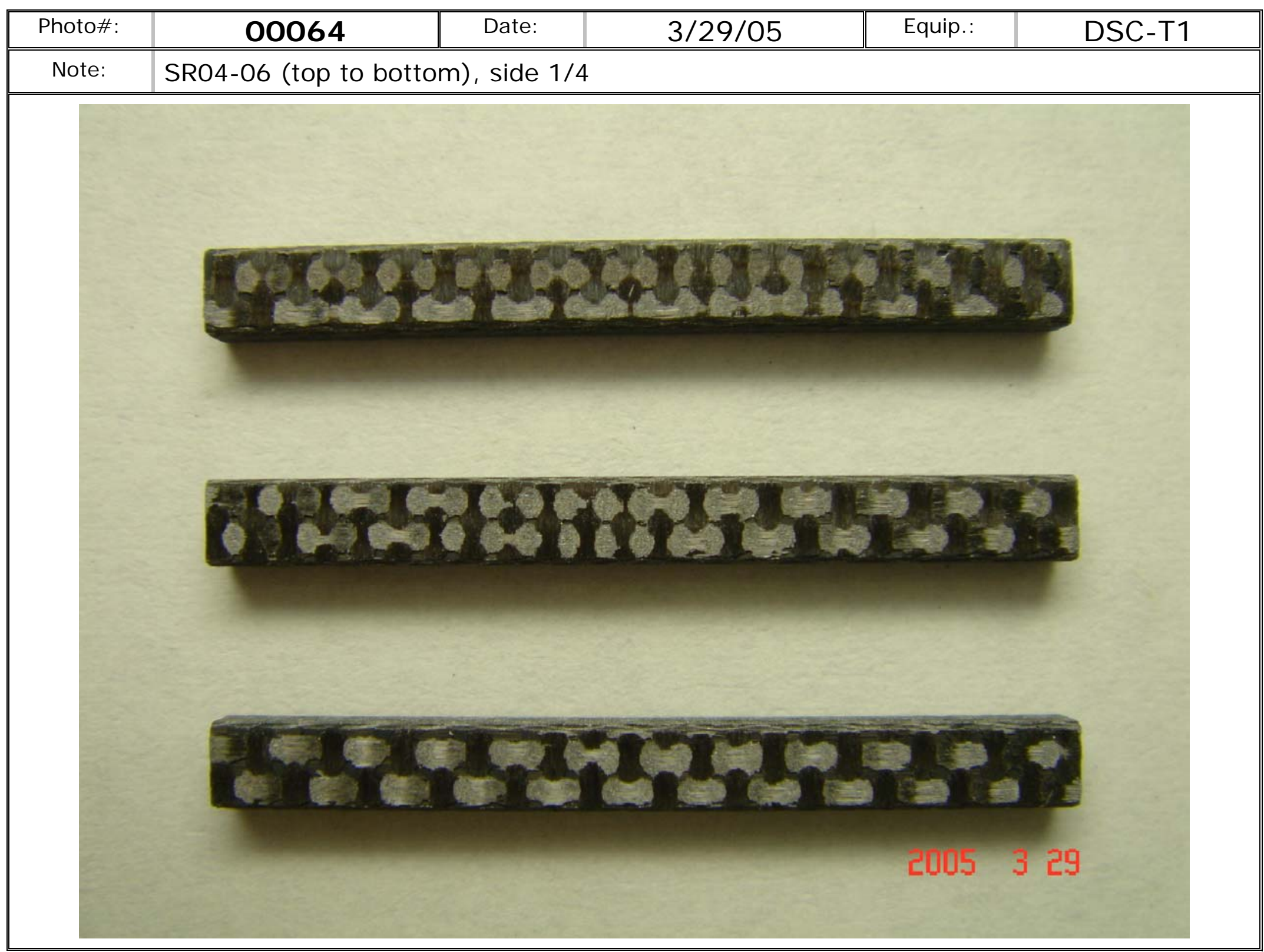




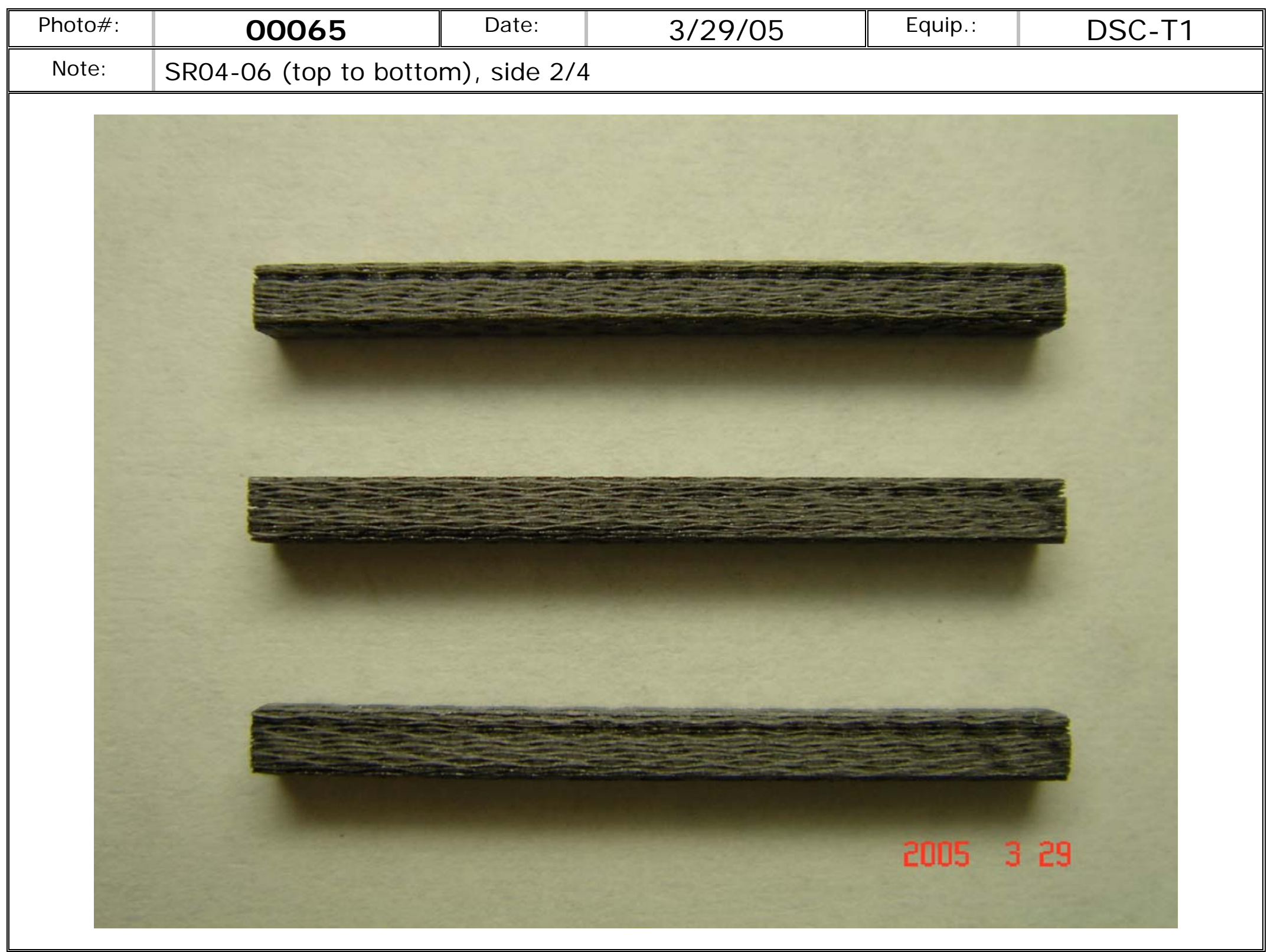




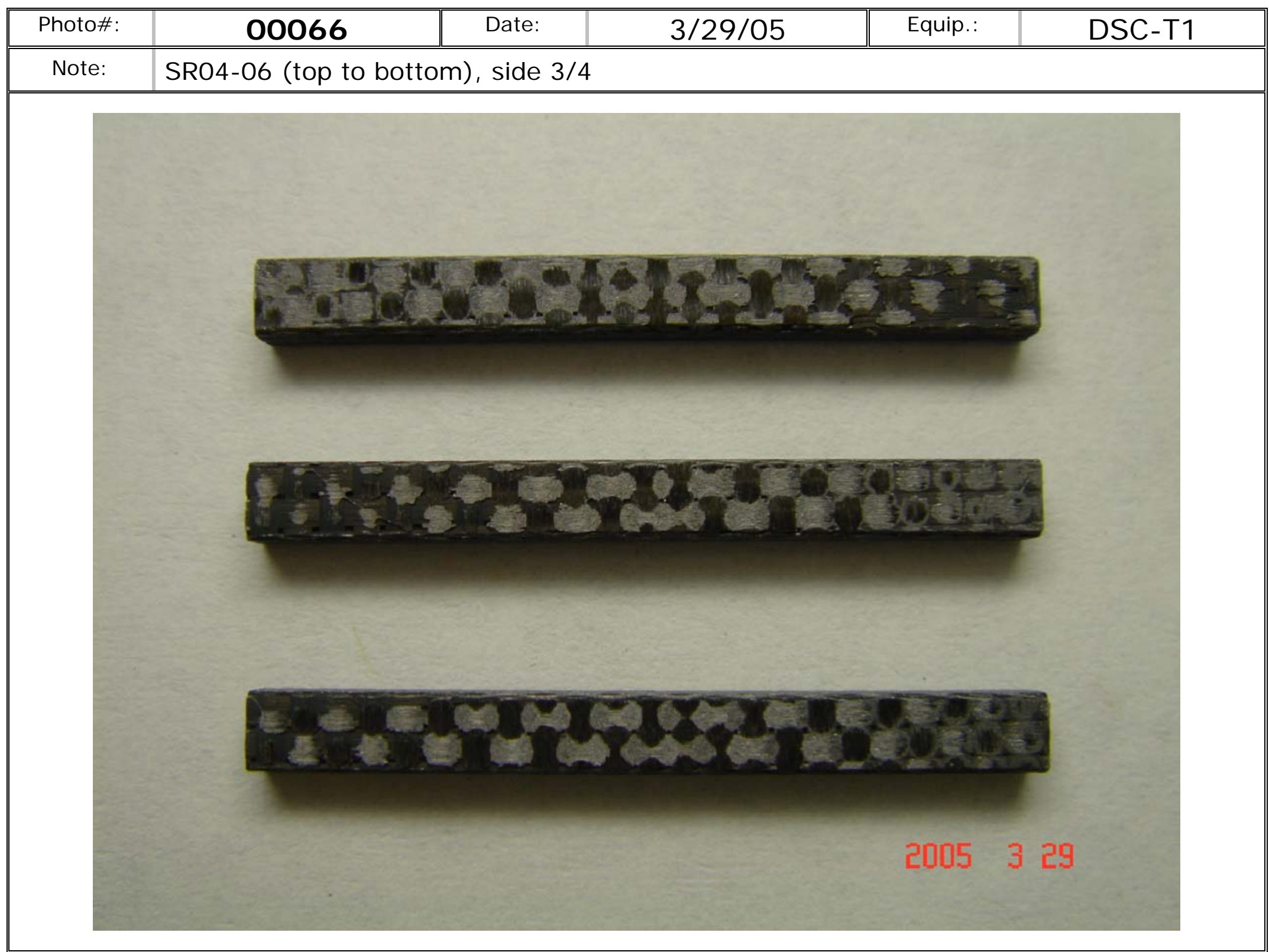




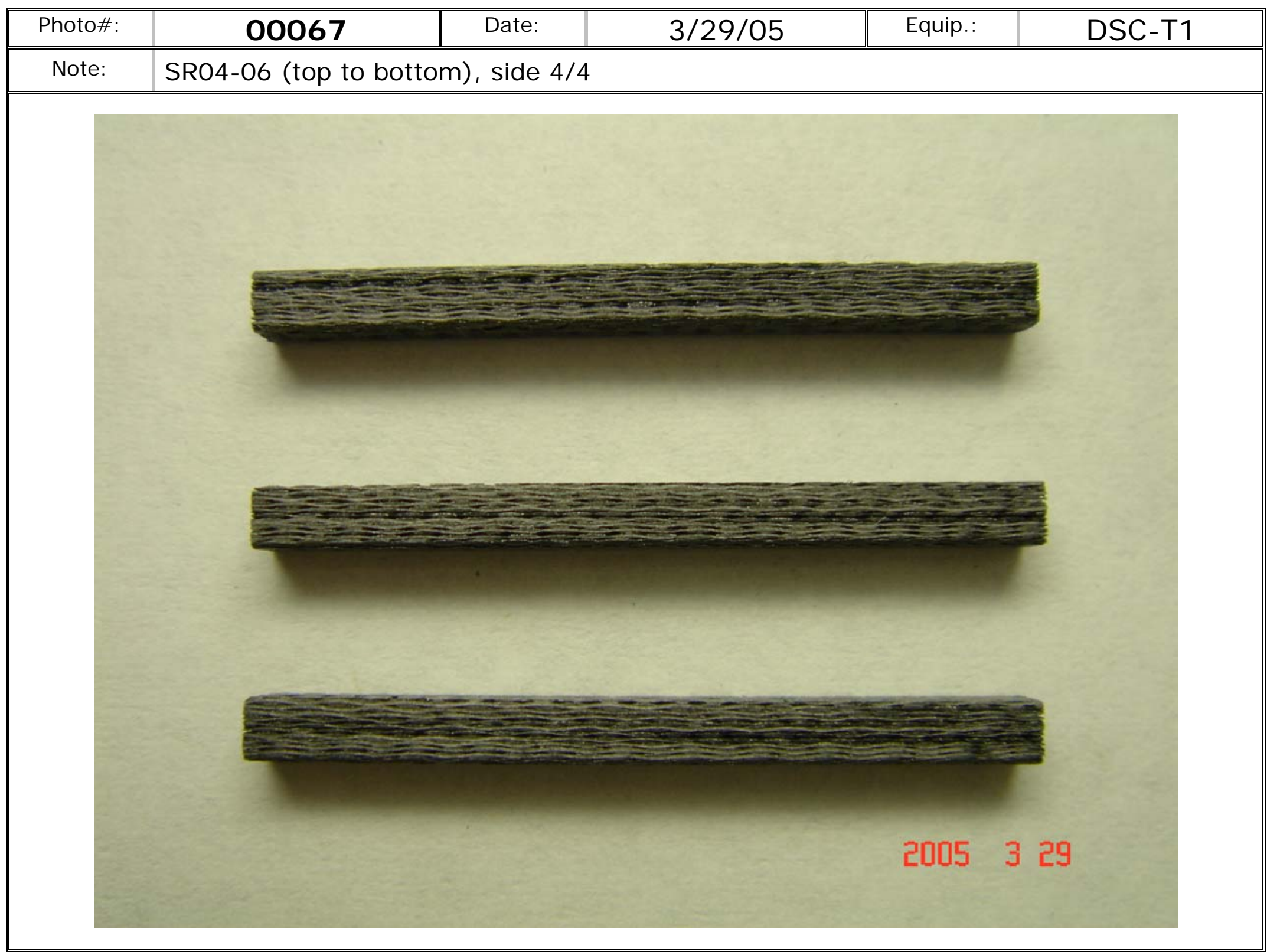




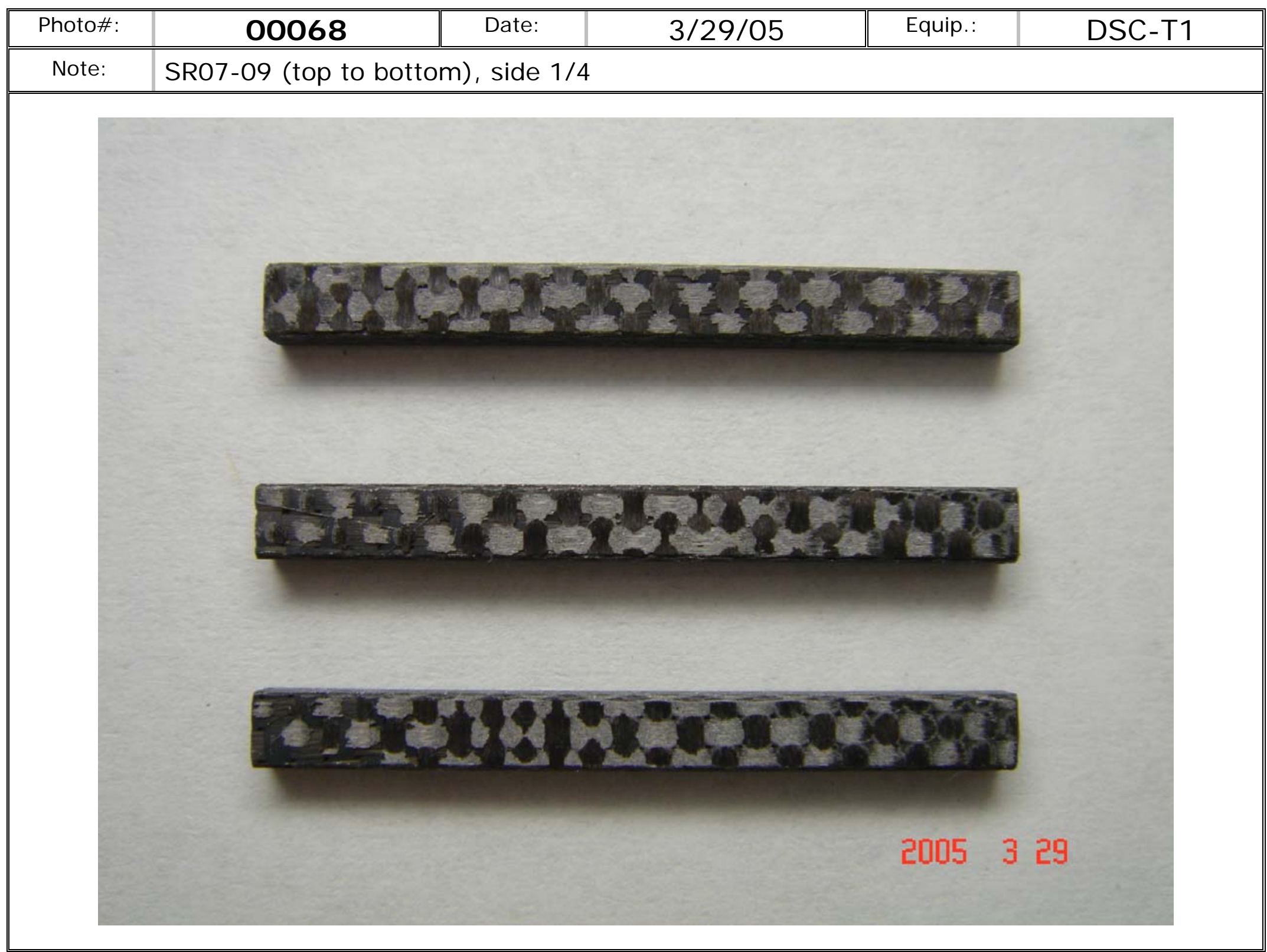




\begin{tabular}{|c|c|c|c|c|c|}
\hline Photo\#: & 00069 & Date: & $3 / 29 / 05$ & Equip.: & DSC-T1 \\
\hline \hline Note: & SR07-09 (top to bottom), side 2/4 & & \\
\hline \hline
\end{tabular}

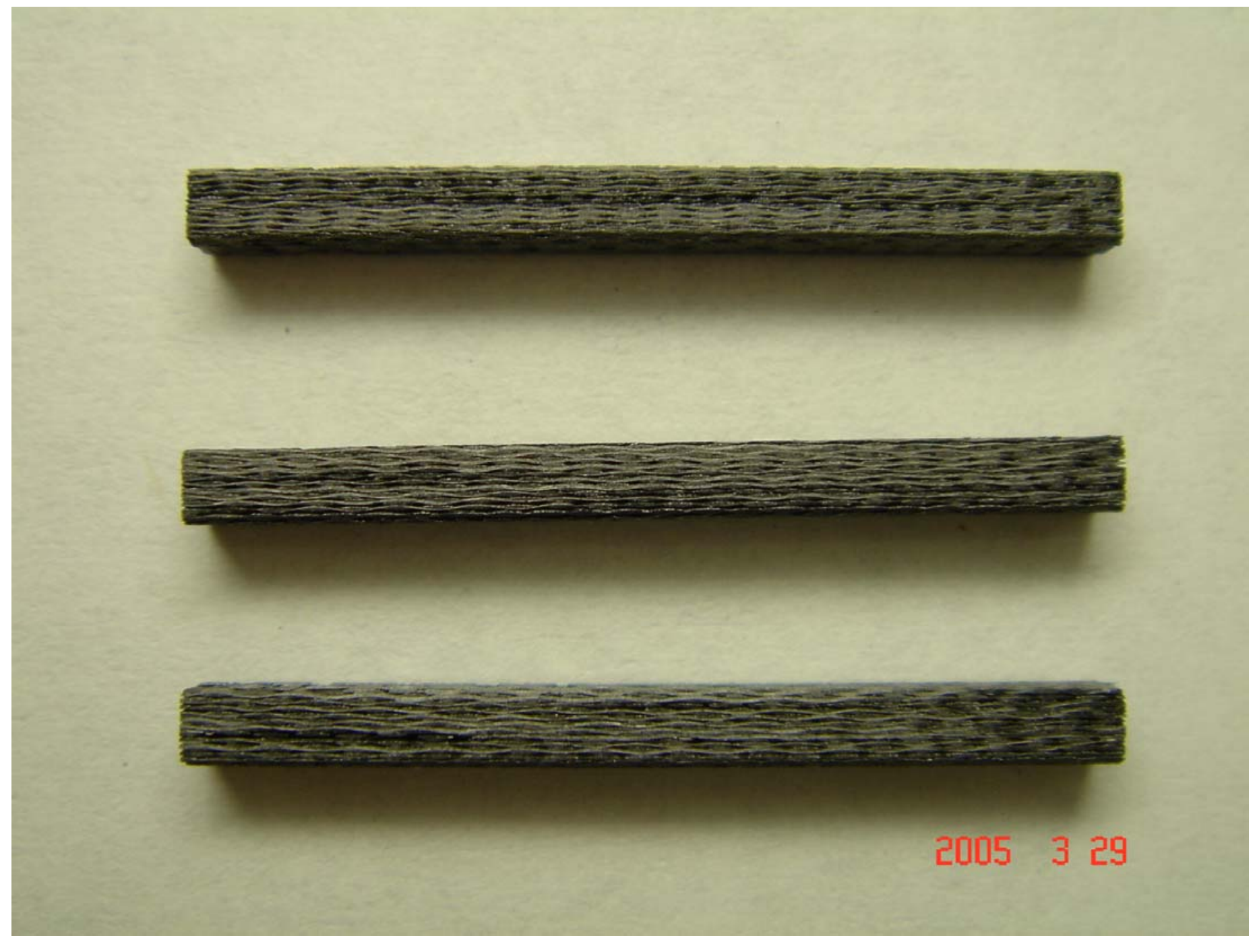




\begin{tabular}{|c|c|c|c|c|c|}
\hline Photo\#: & 00070 & Date: & $3 / 29 / 05$ & Equip.: & DSC-T1 \\
\hline \hline Note: & SR07-09 (top to bottom), side 3/4 & & \\
\hline \hline
\end{tabular}

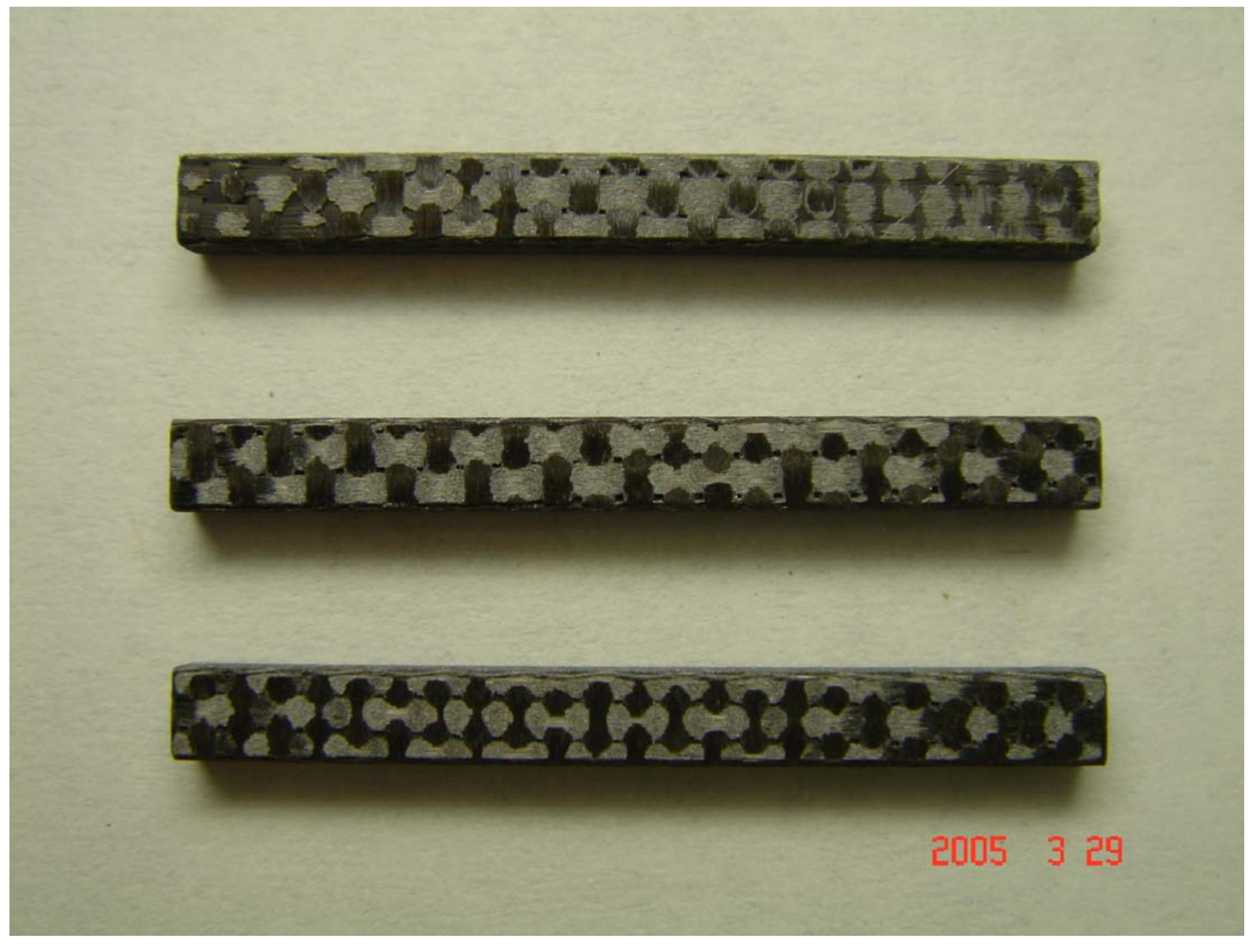




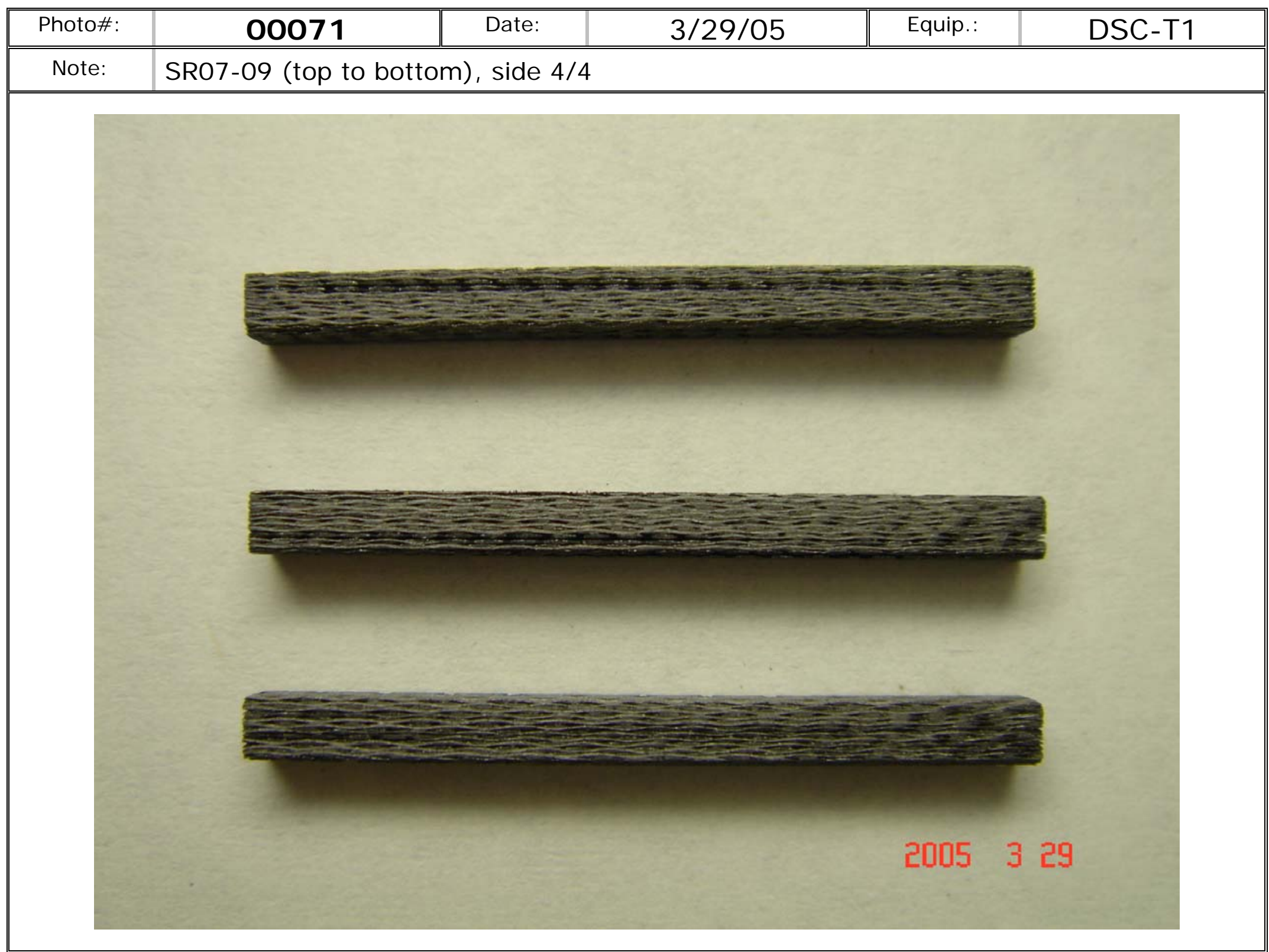




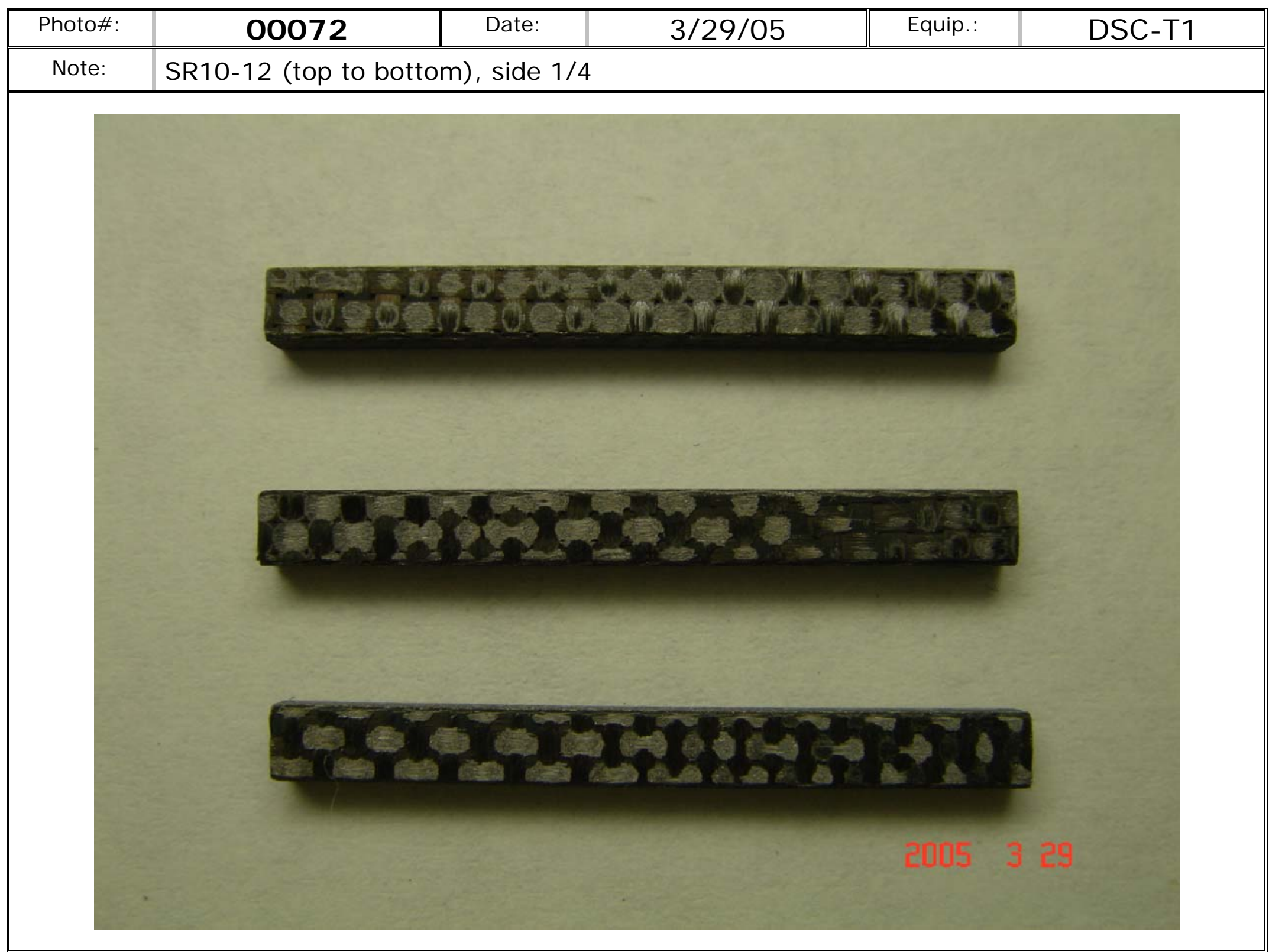




\begin{tabular}{|c|c|c|c|c|c|}
\hline Photo\#: & $\mathbf{0 0 0 7 3}$ & Date: & $3 / 29 / 05$ & Equip.: & DSC-T1 \\
\hline \hline Note: & SR10-12 (top to bottom), side 2/4 & & \\
\hline \hline
\end{tabular}

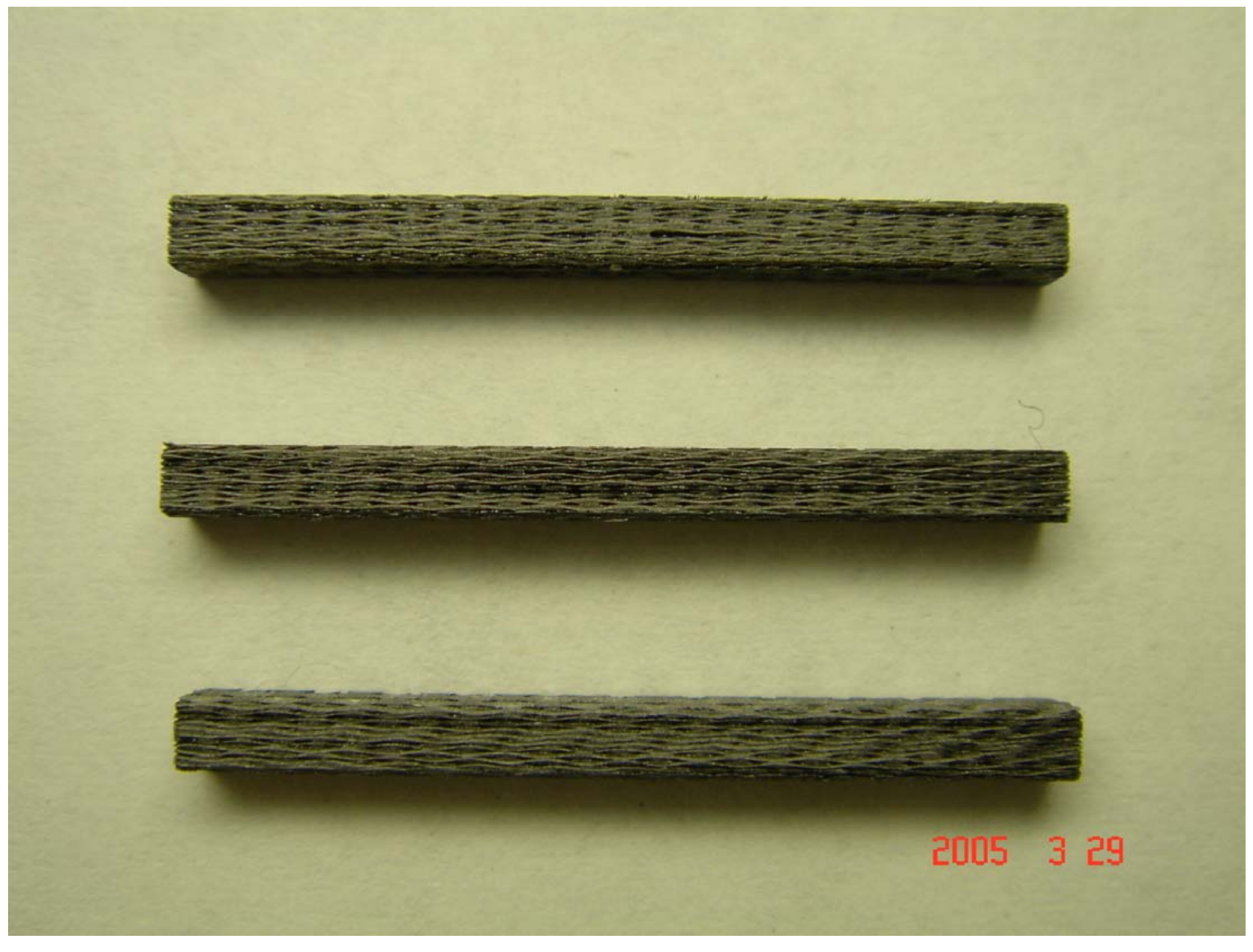




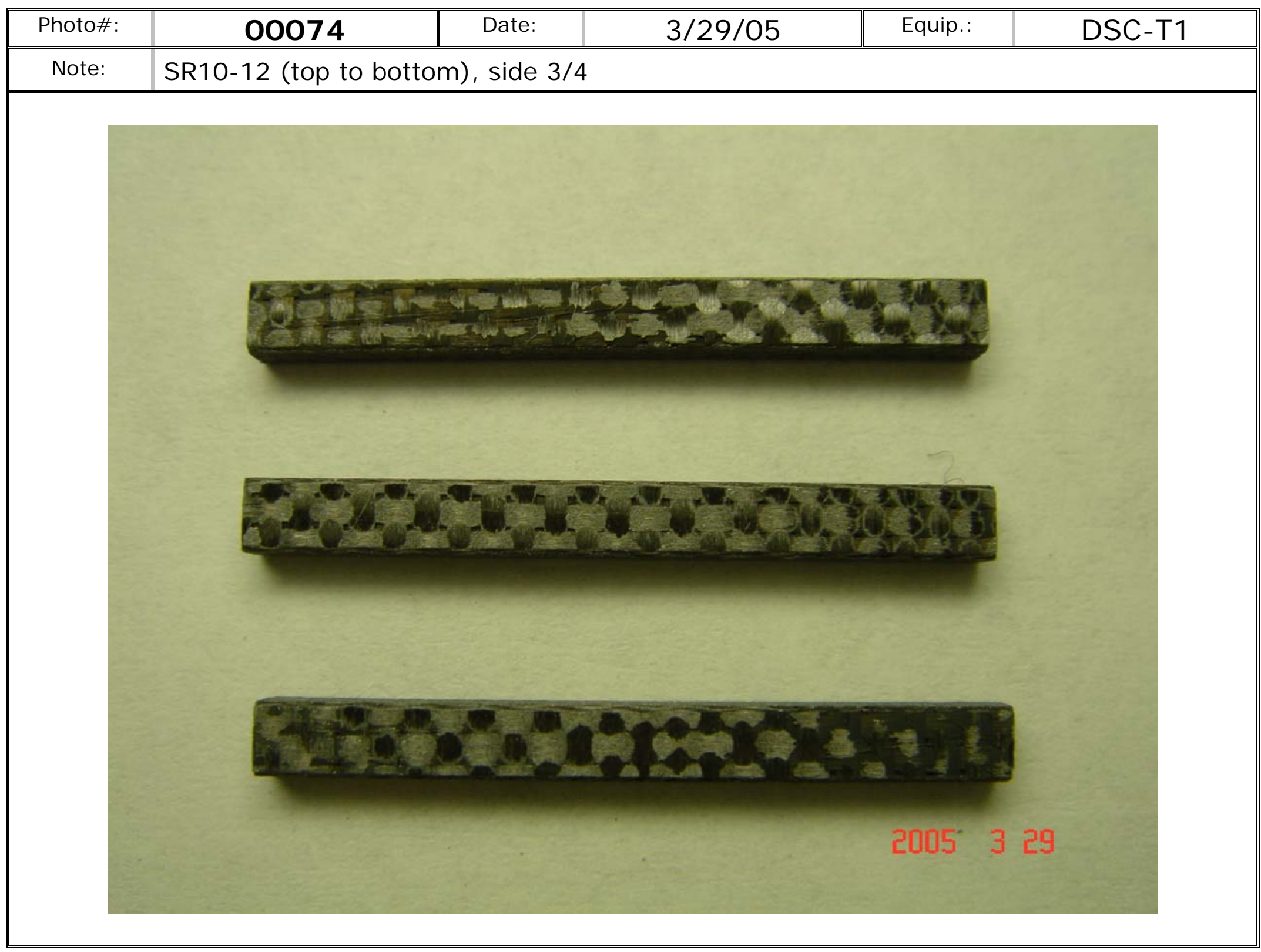




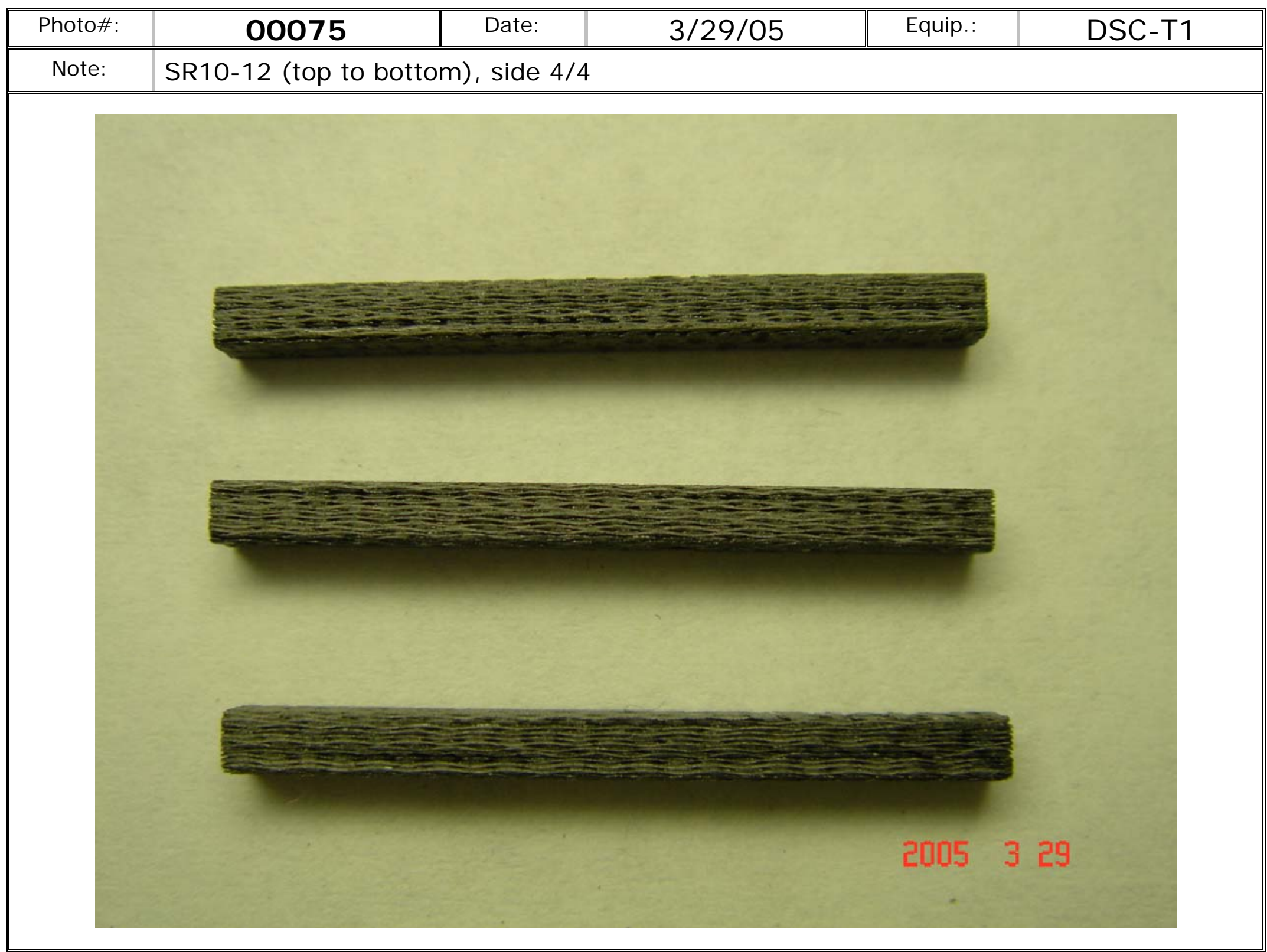




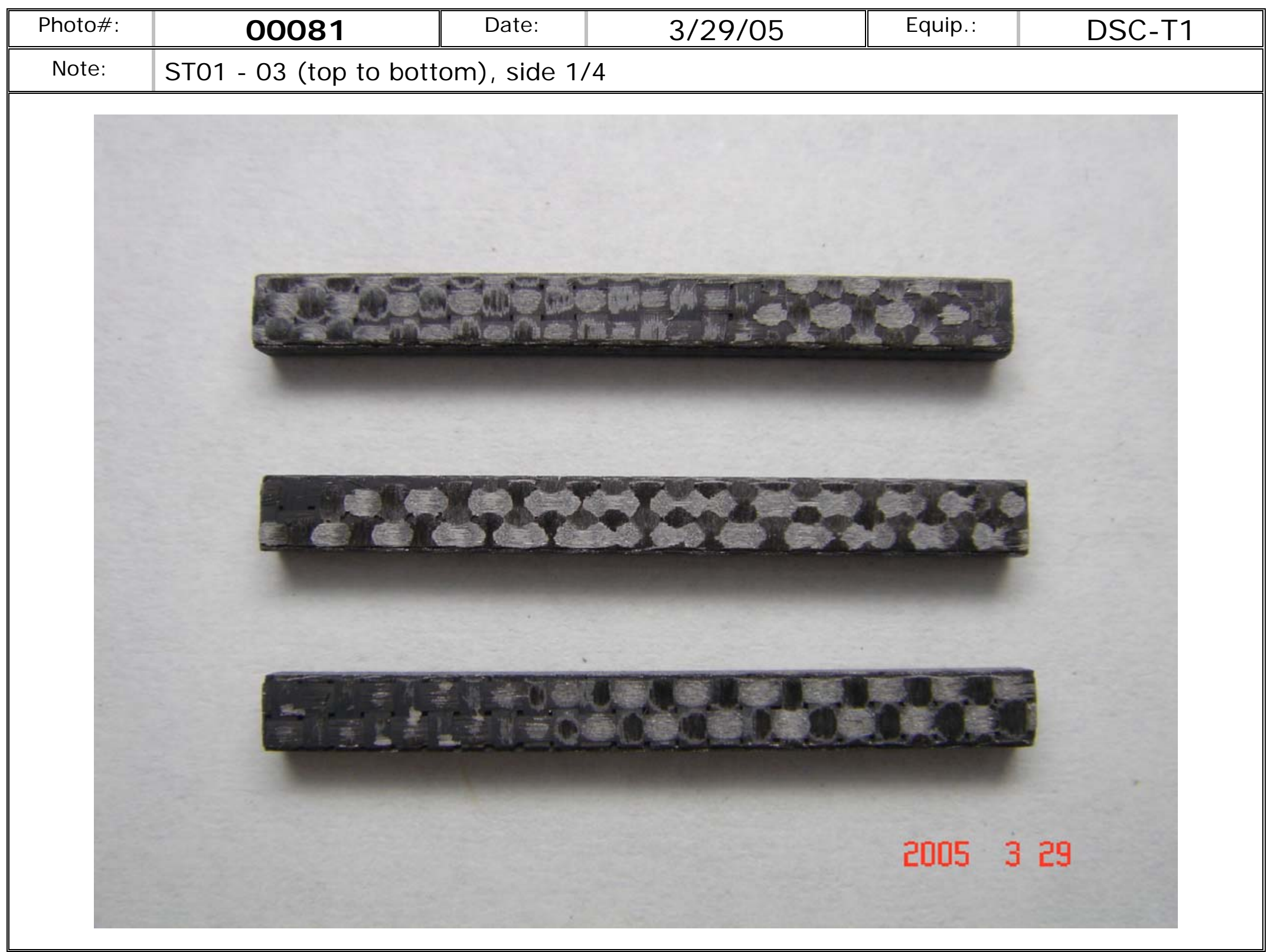




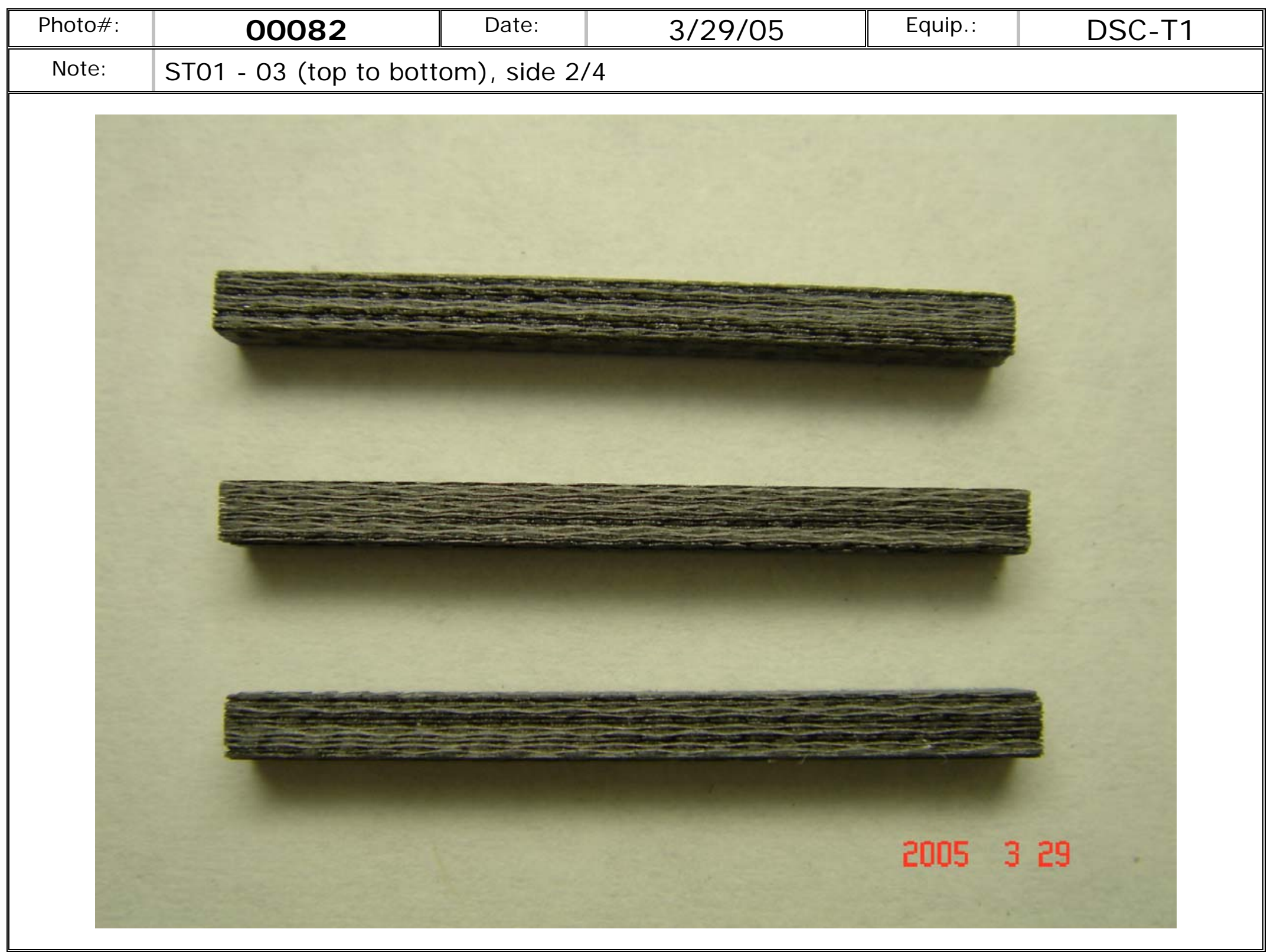




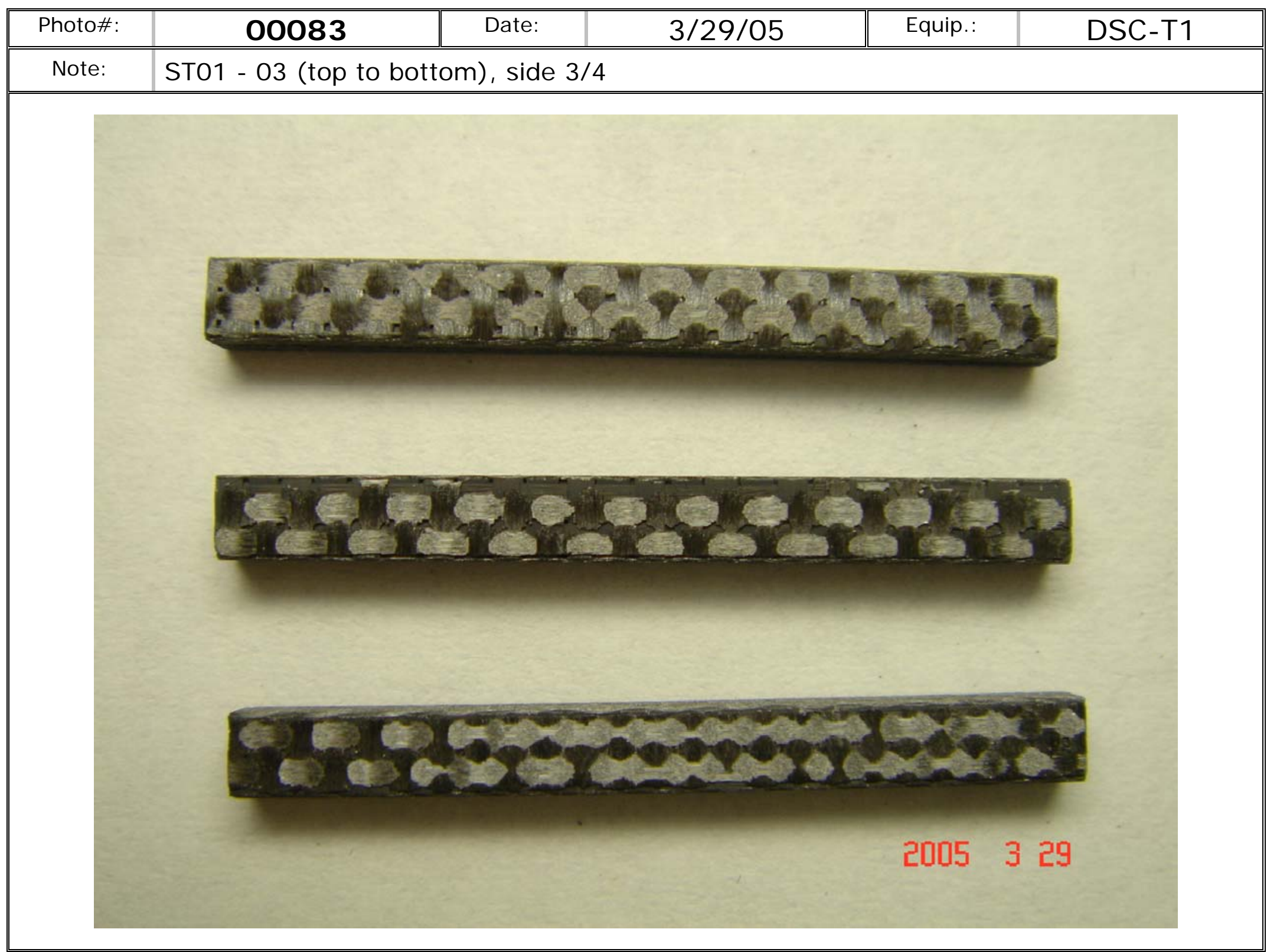




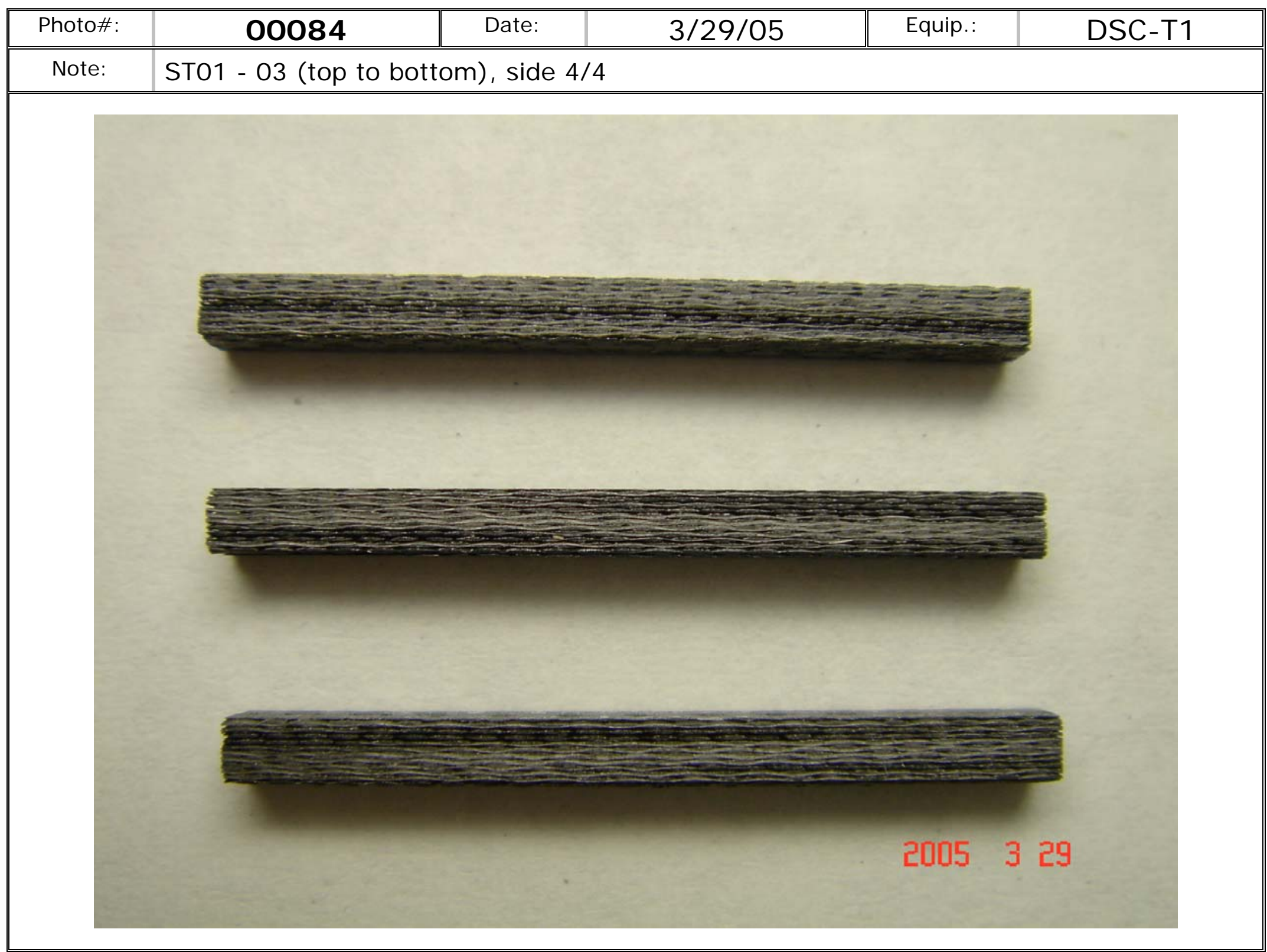




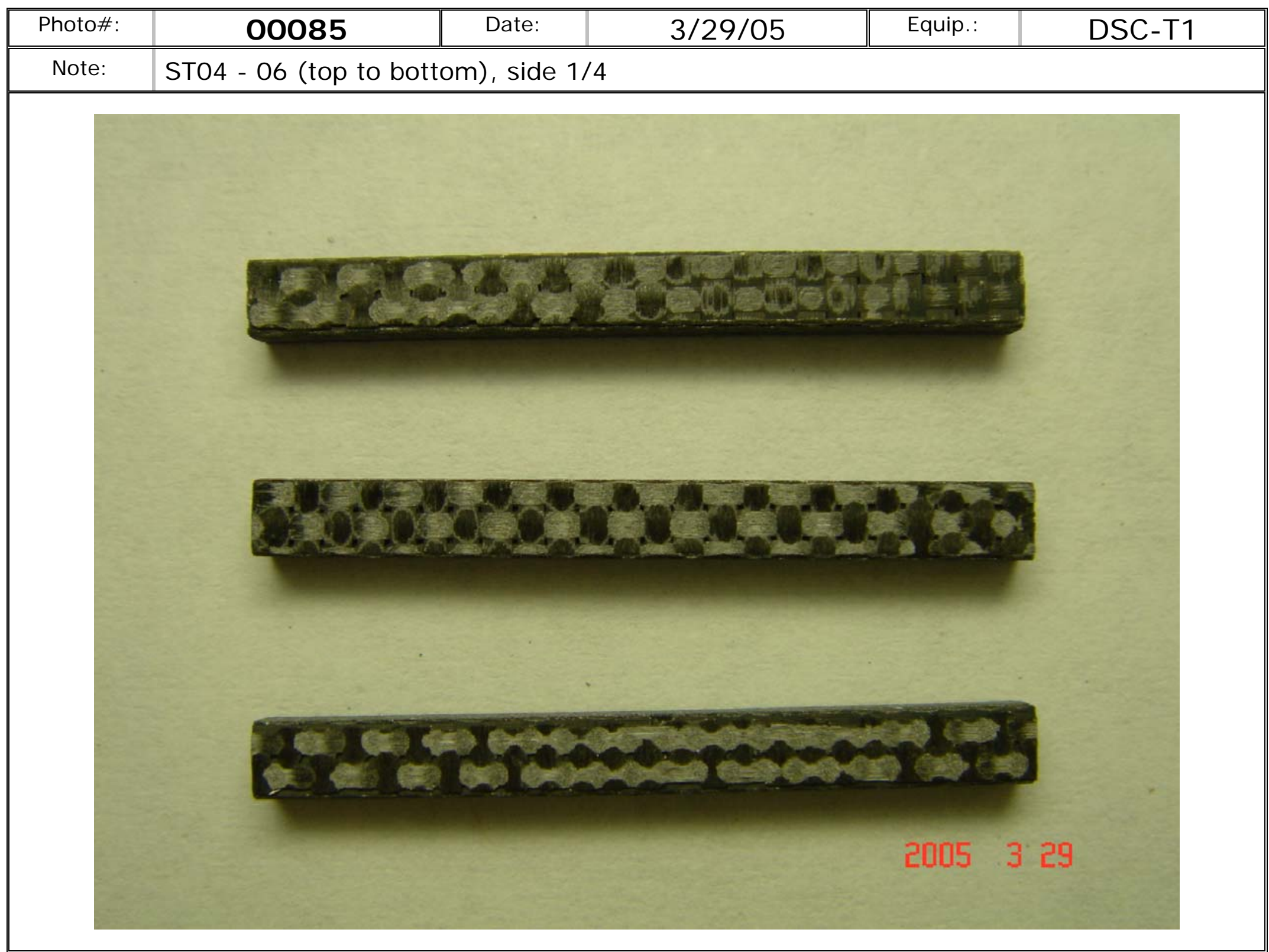




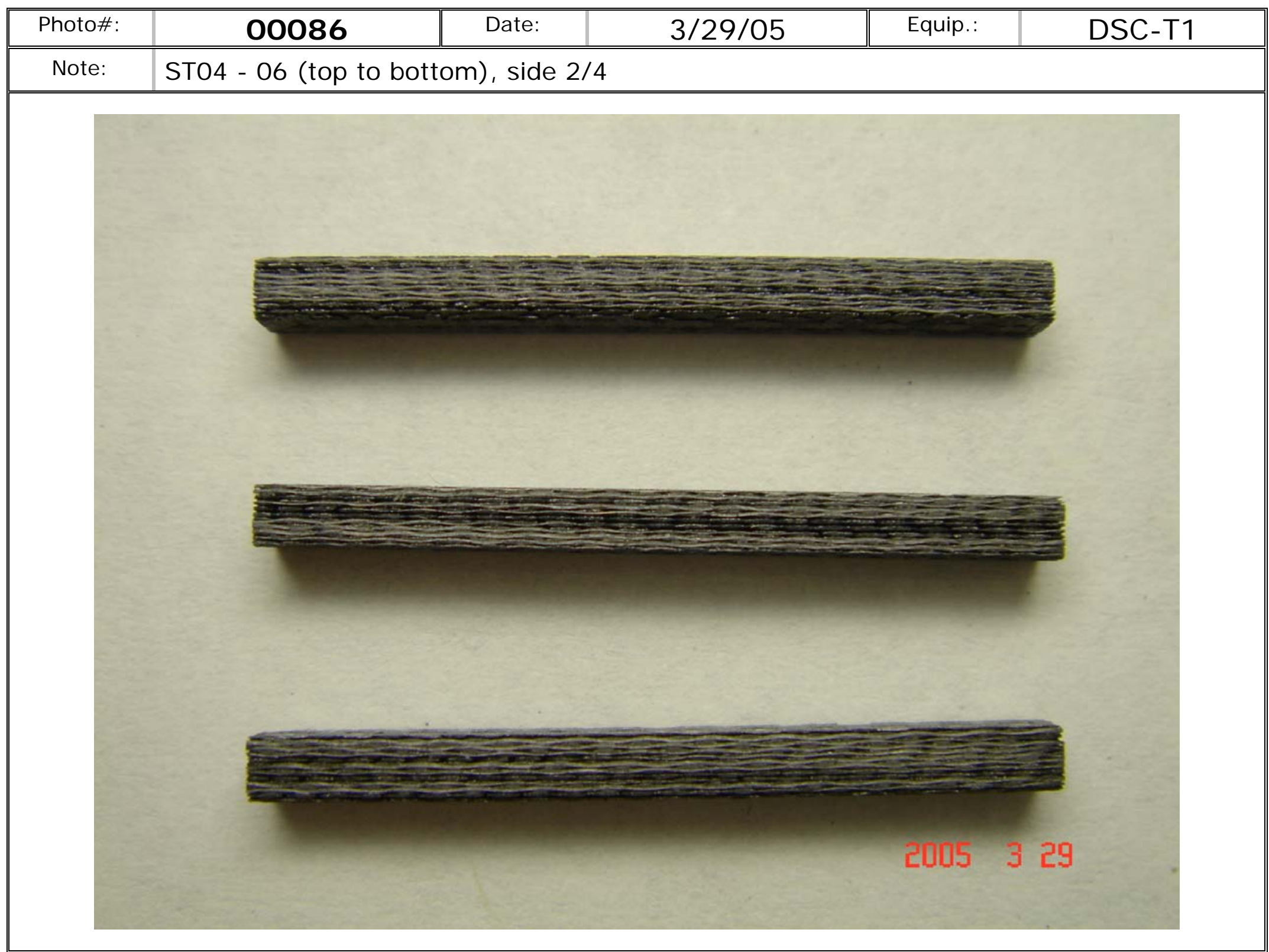




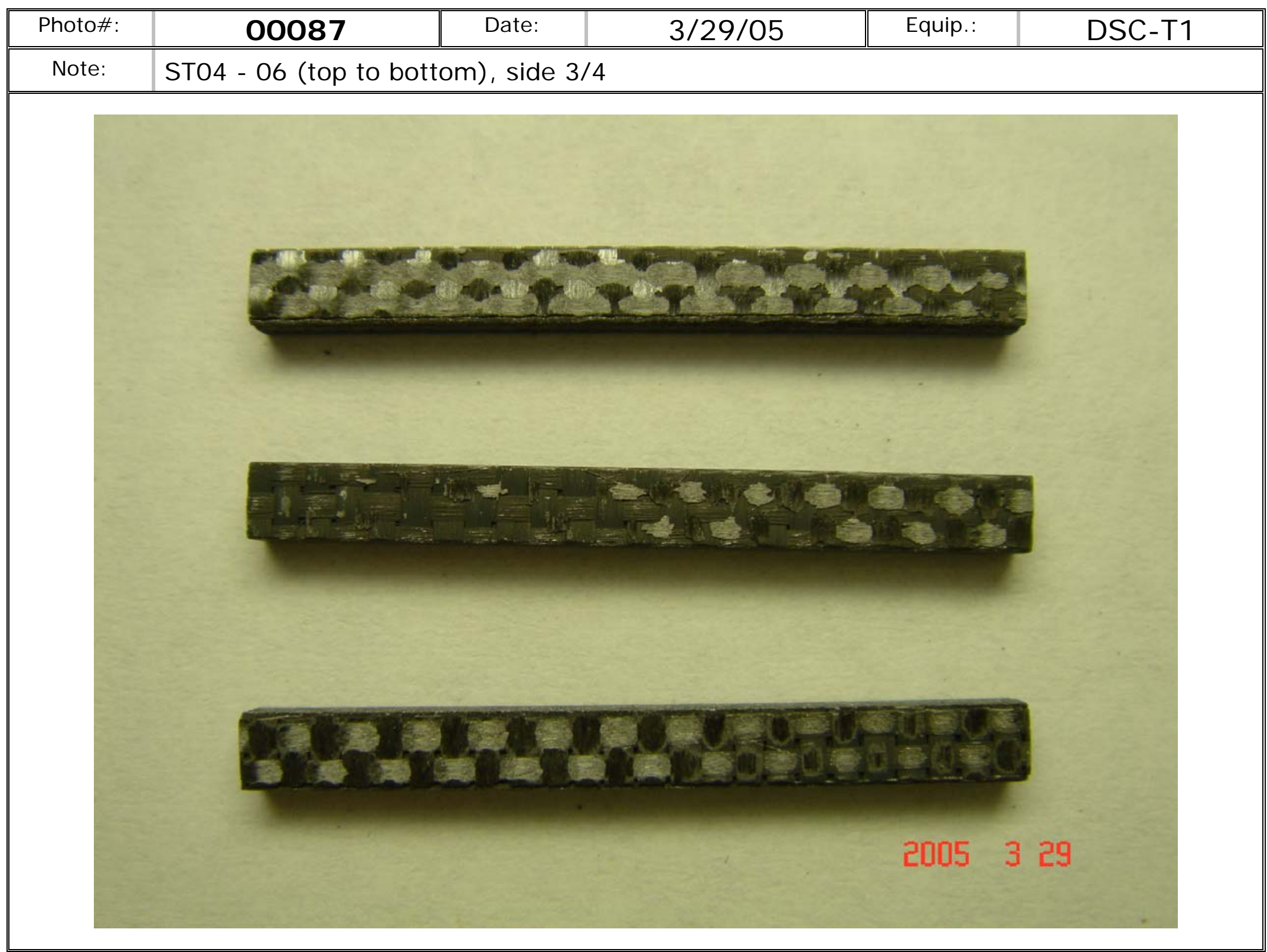




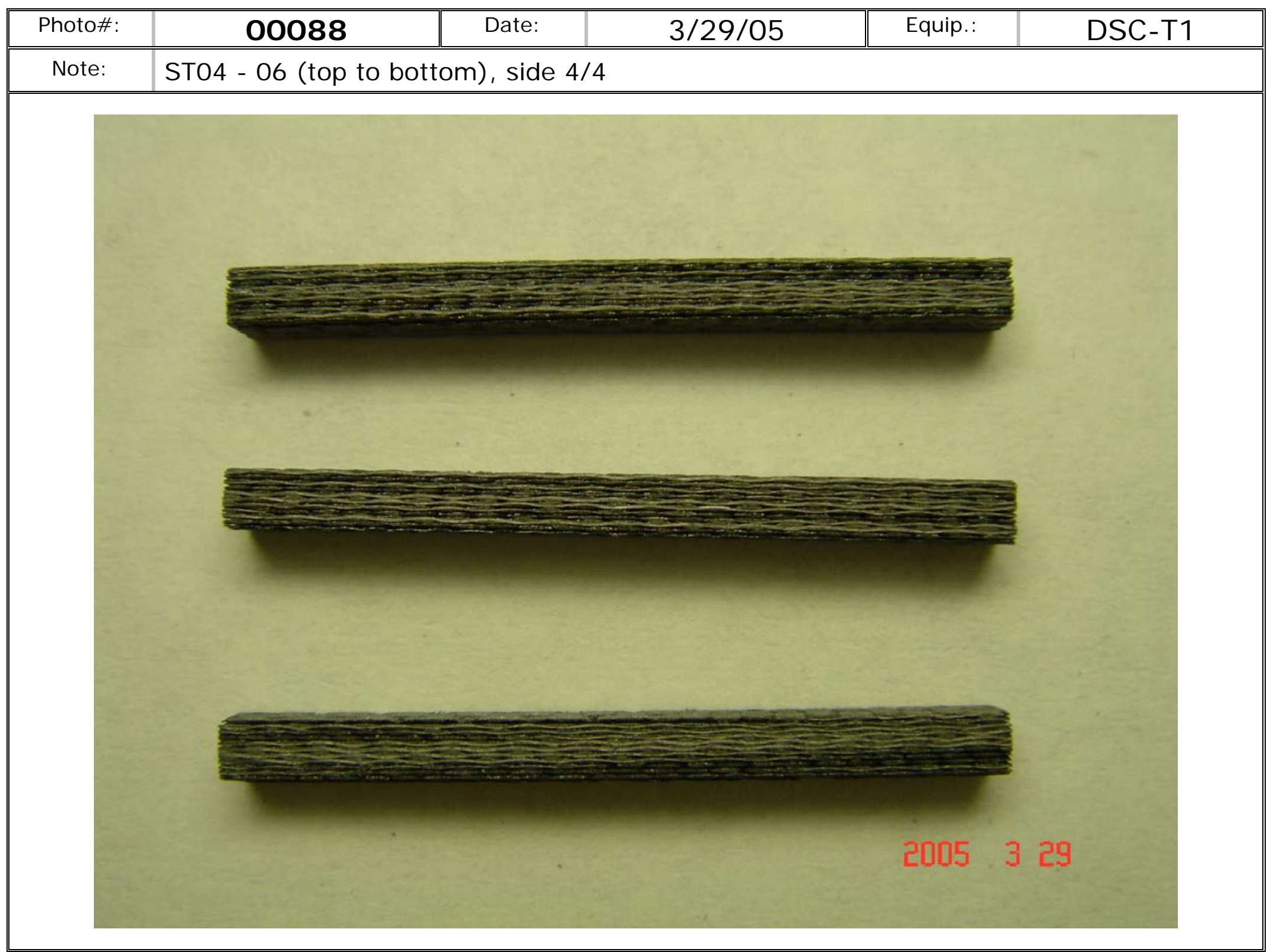




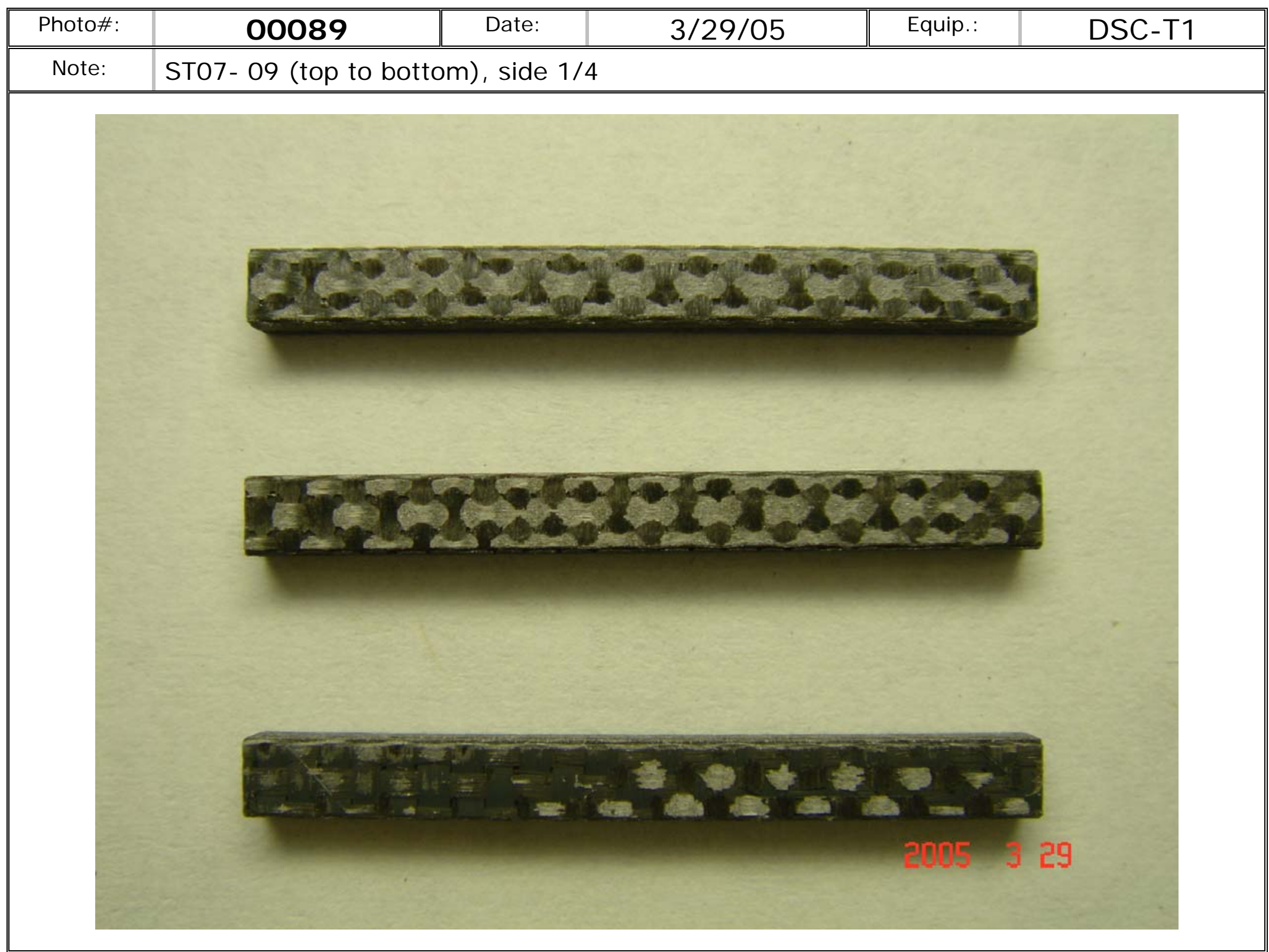




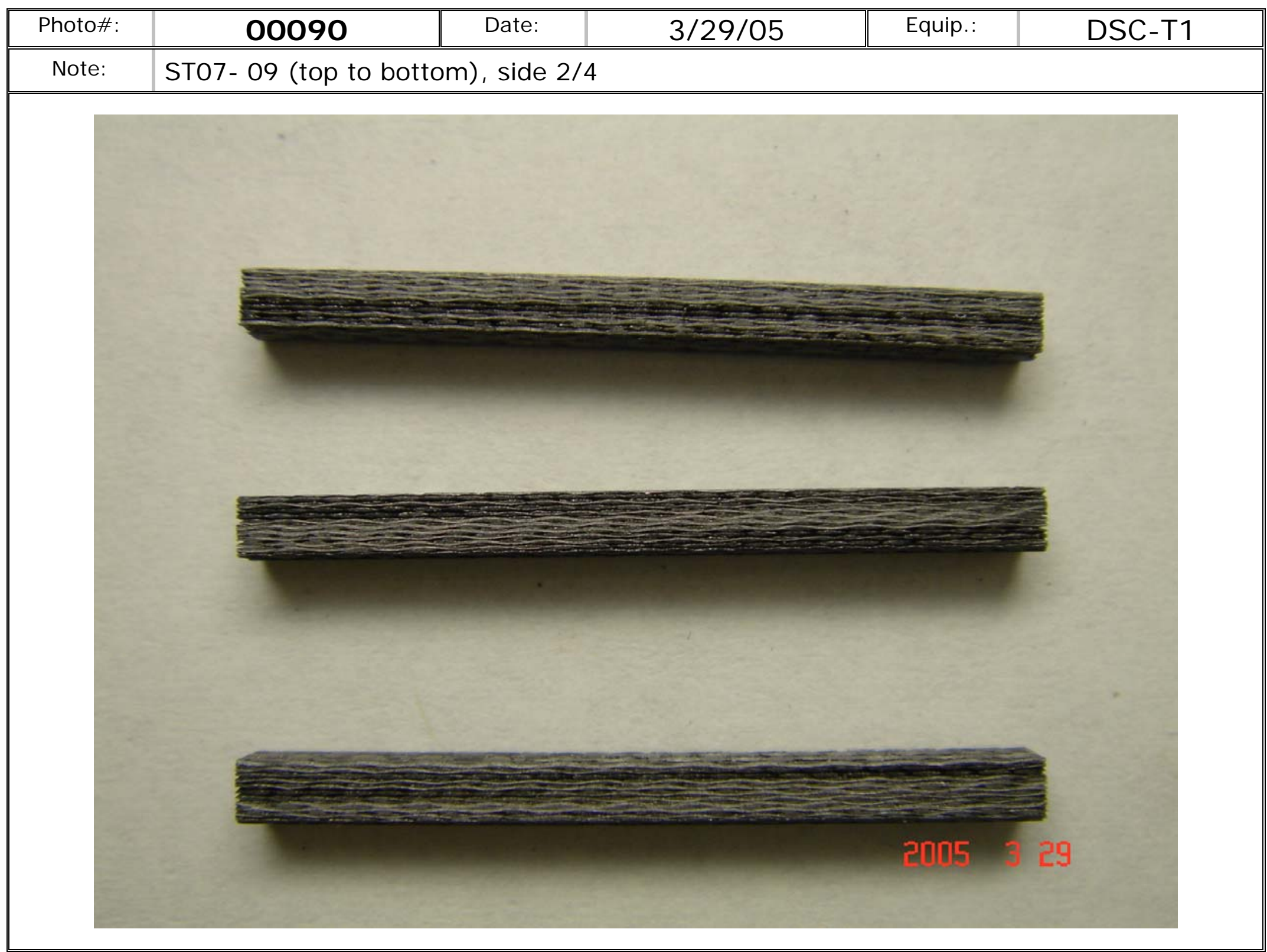




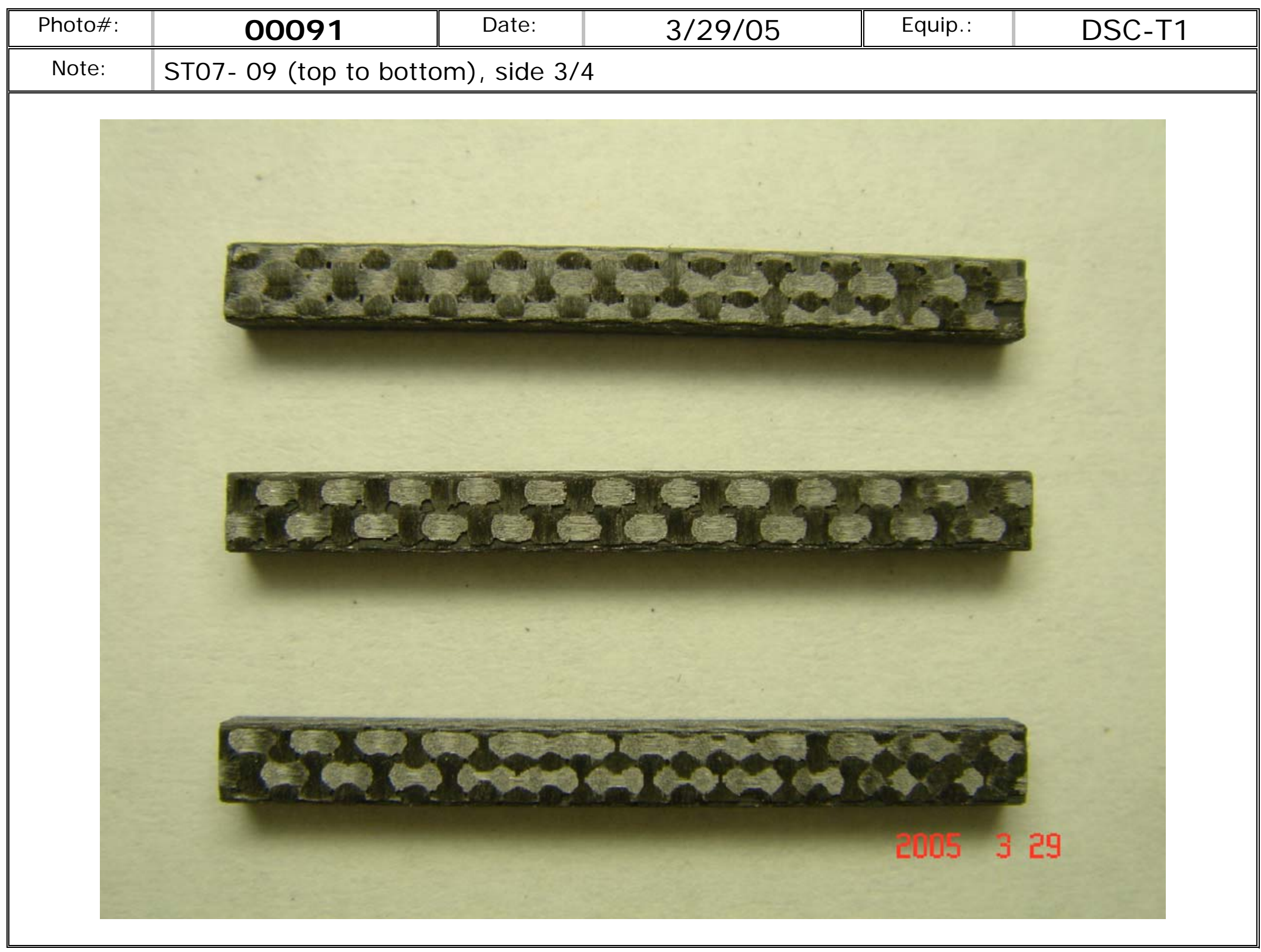




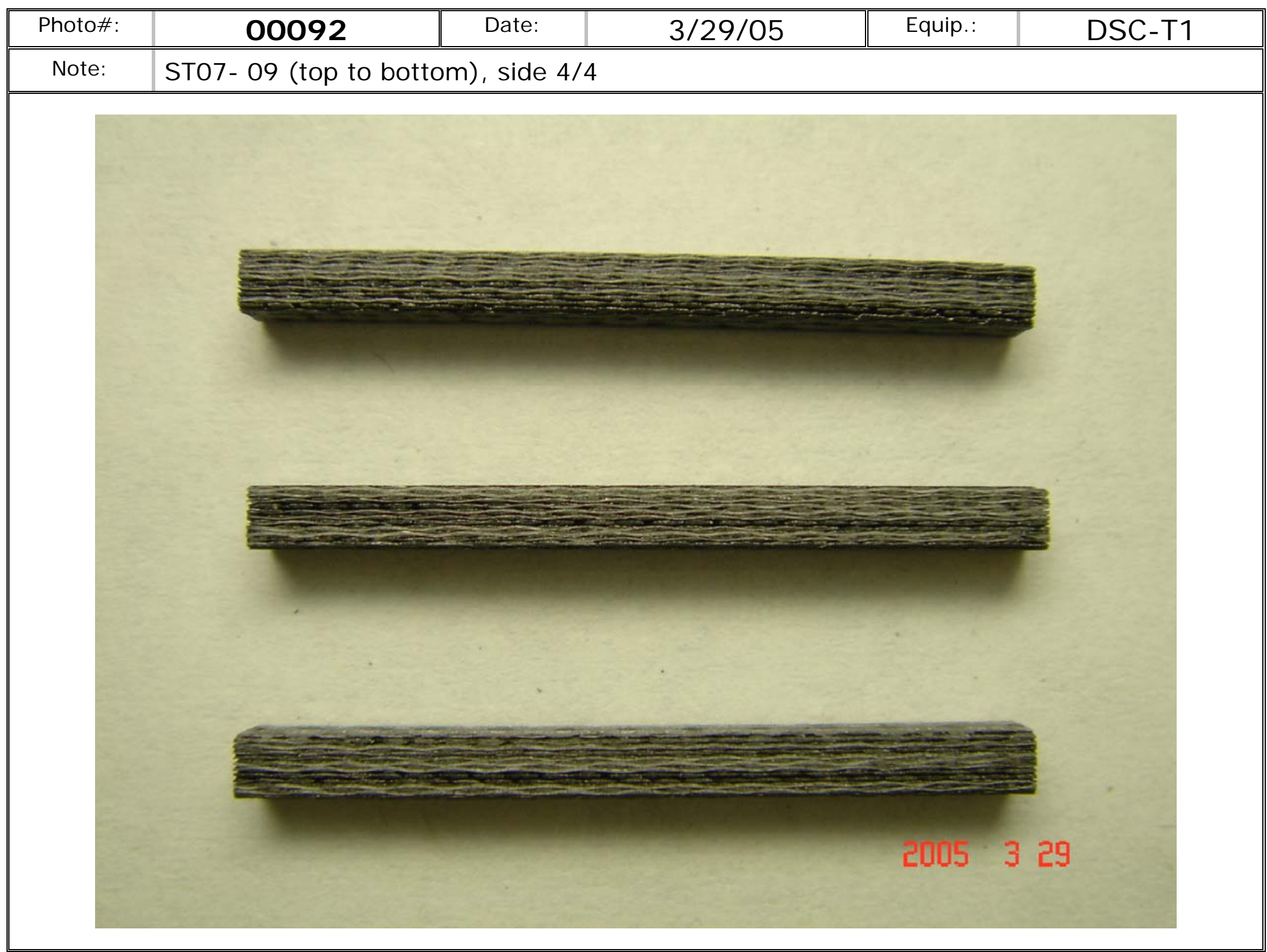




\begin{tabular}{|c|c|c|c|c|c|}
\hline Photo\#: & $\mathbf{0 0 0 9 3}$ & Date: & $3 / 29 / 05$ & Equip.: & DSC-T1 \\
\hline \hline Note: & ST10- 12 (top to bottom), side $1 / 4$ & & \\
\hline \hline
\end{tabular}
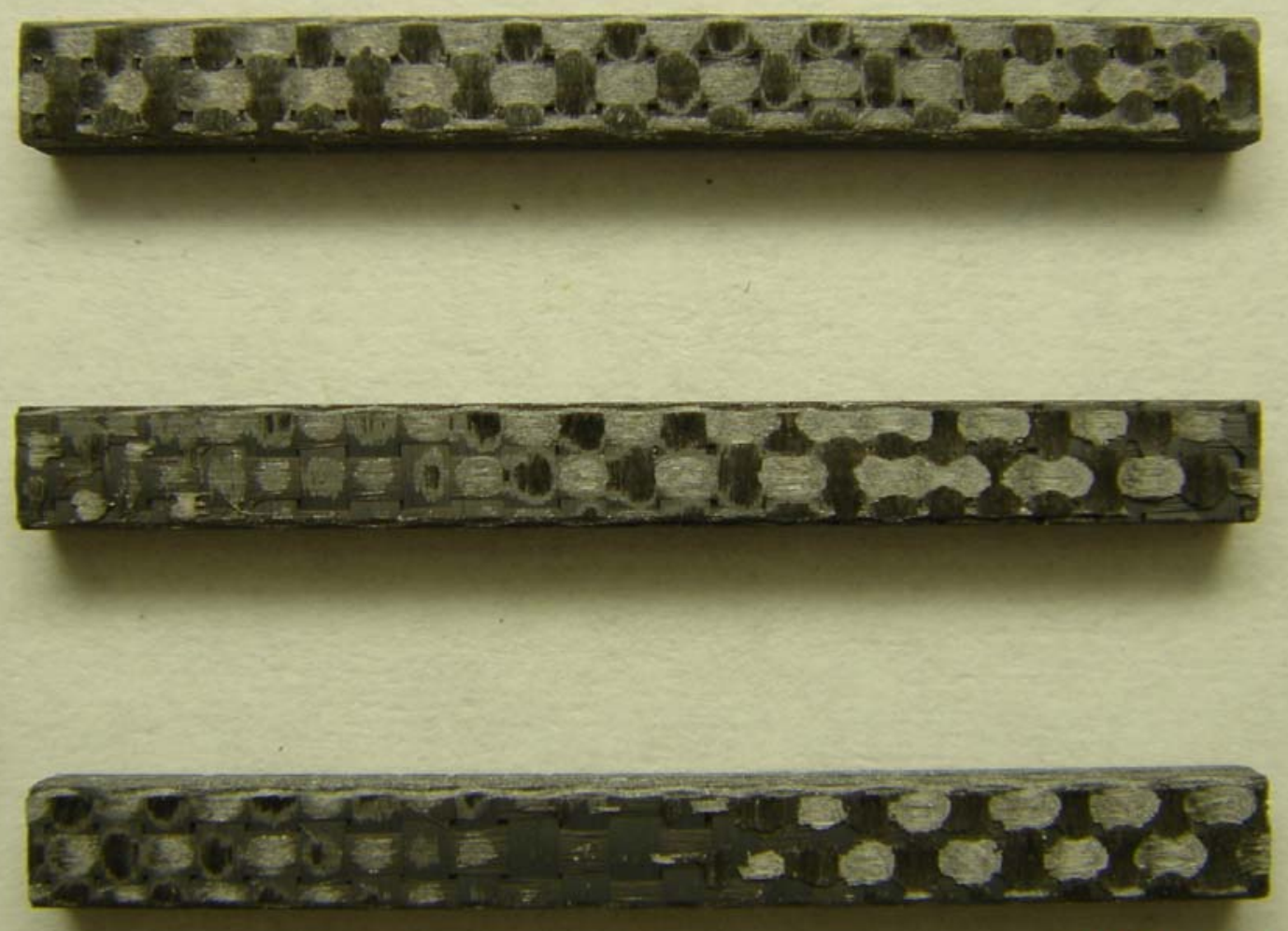


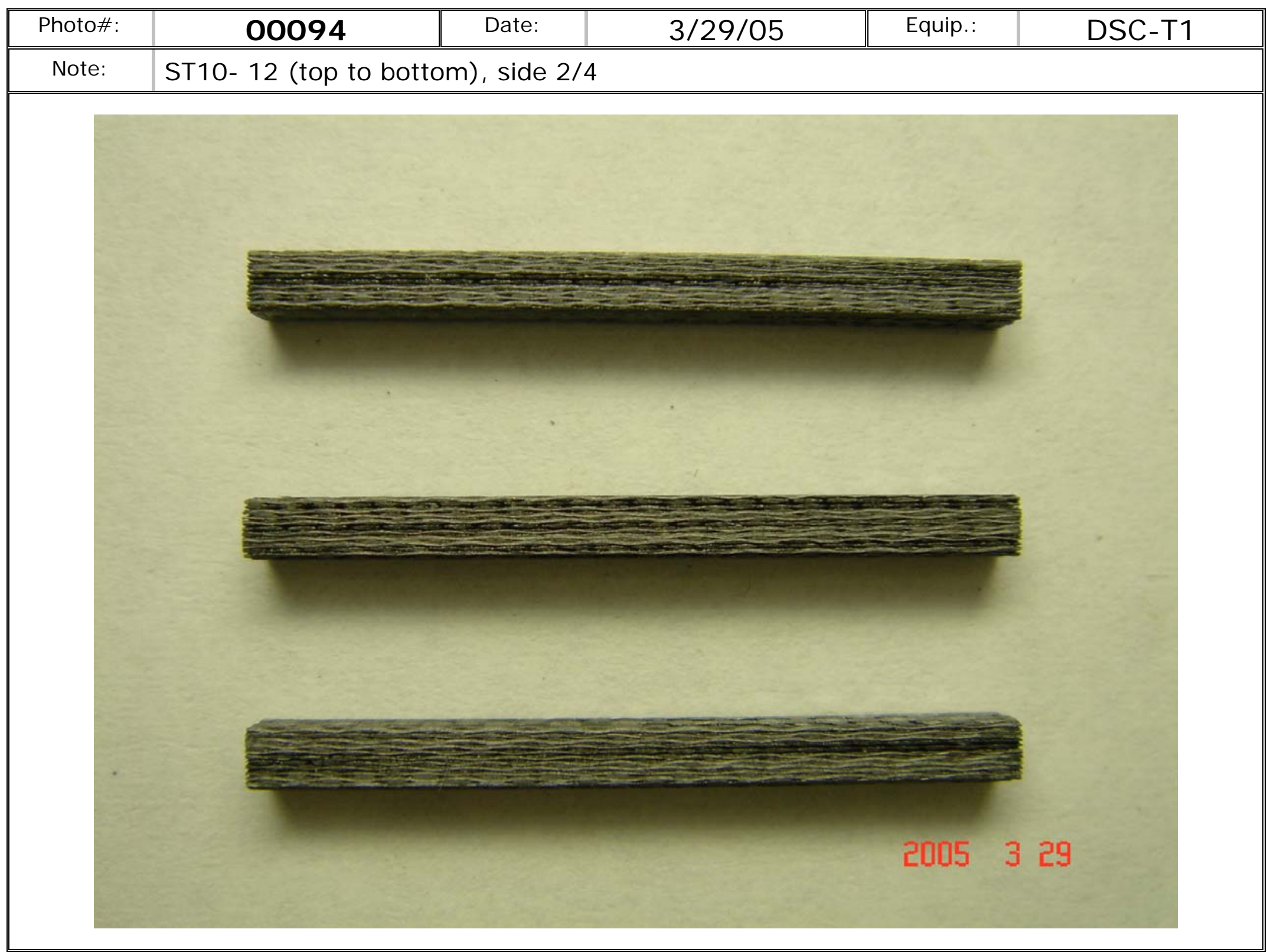




\begin{tabular}{|c|c|c|c|c|c|}
\hline Photo\#: & $\mathbf{0 0 0 9 5}$ & Date: & $3 / 29 / 05$ & Equip.: & DSC-T1 \\
\hline \hline Note: & ST10- 12 (top to bottom), side 3/4 & & \\
\hline \hline
\end{tabular}

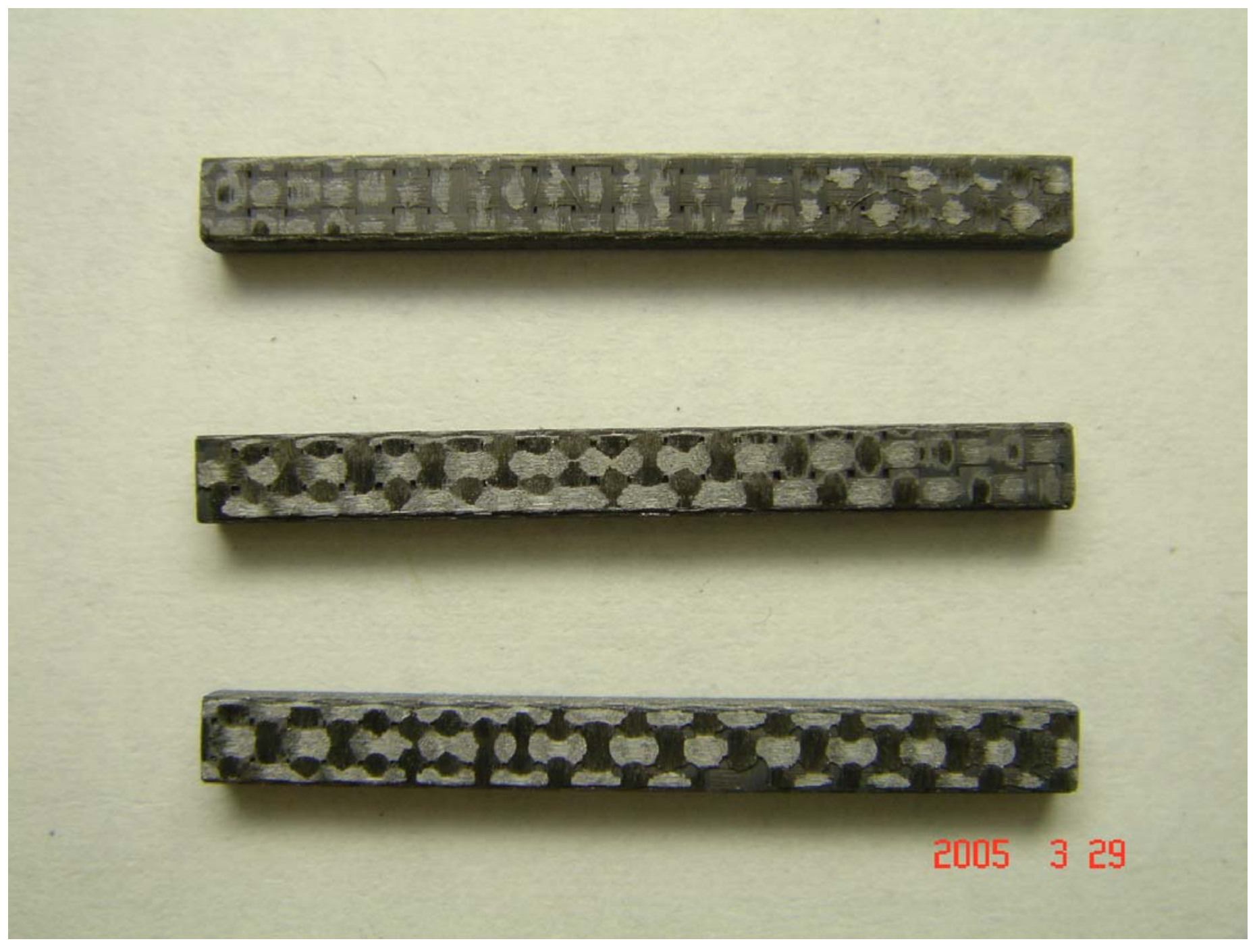




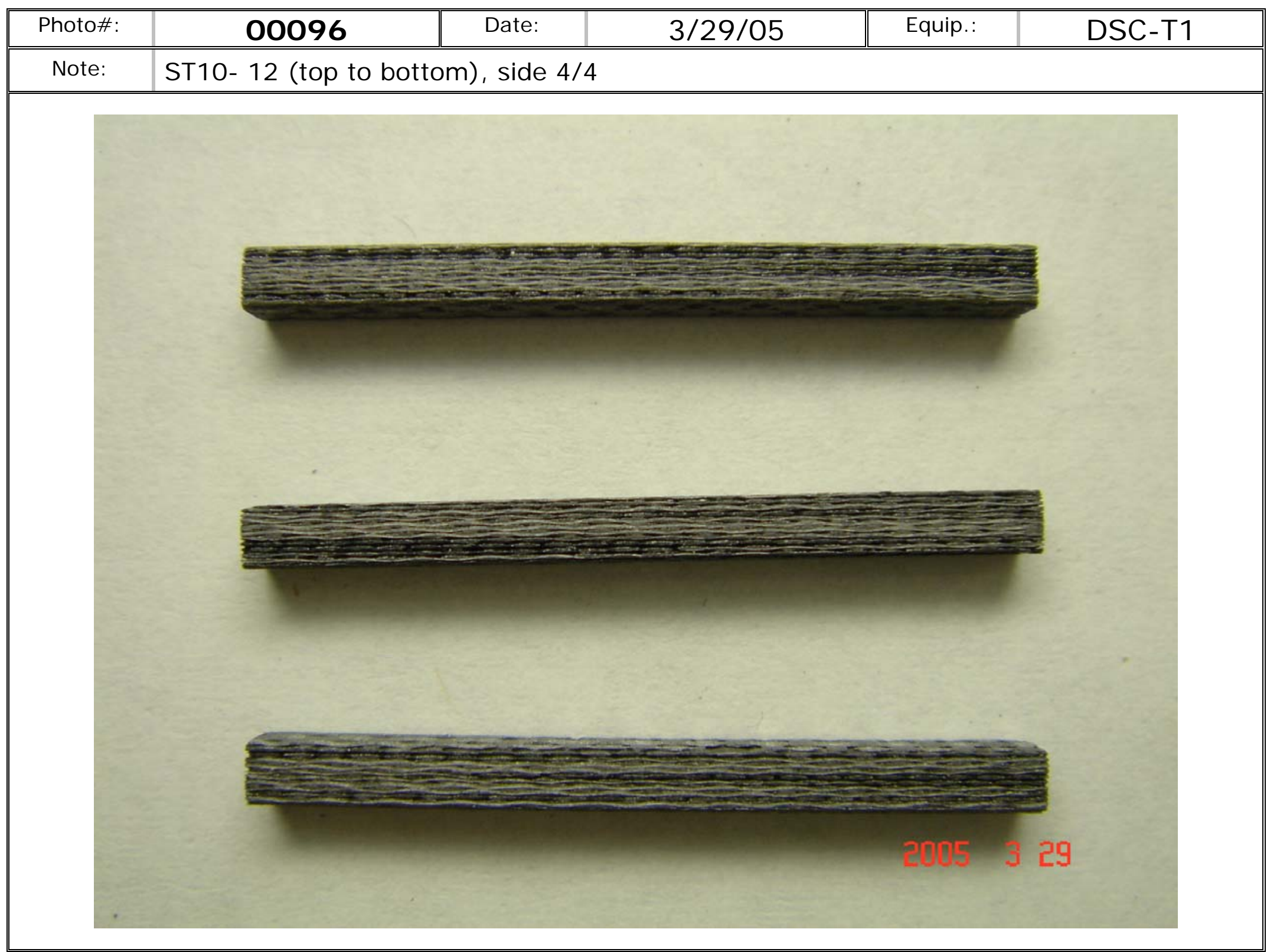




$$
\text { II }
$$


File: A6_Futurix-MI_ORNL_Specimen_Photos

Printed 5/ 9/ 2005 Page 54 / 76

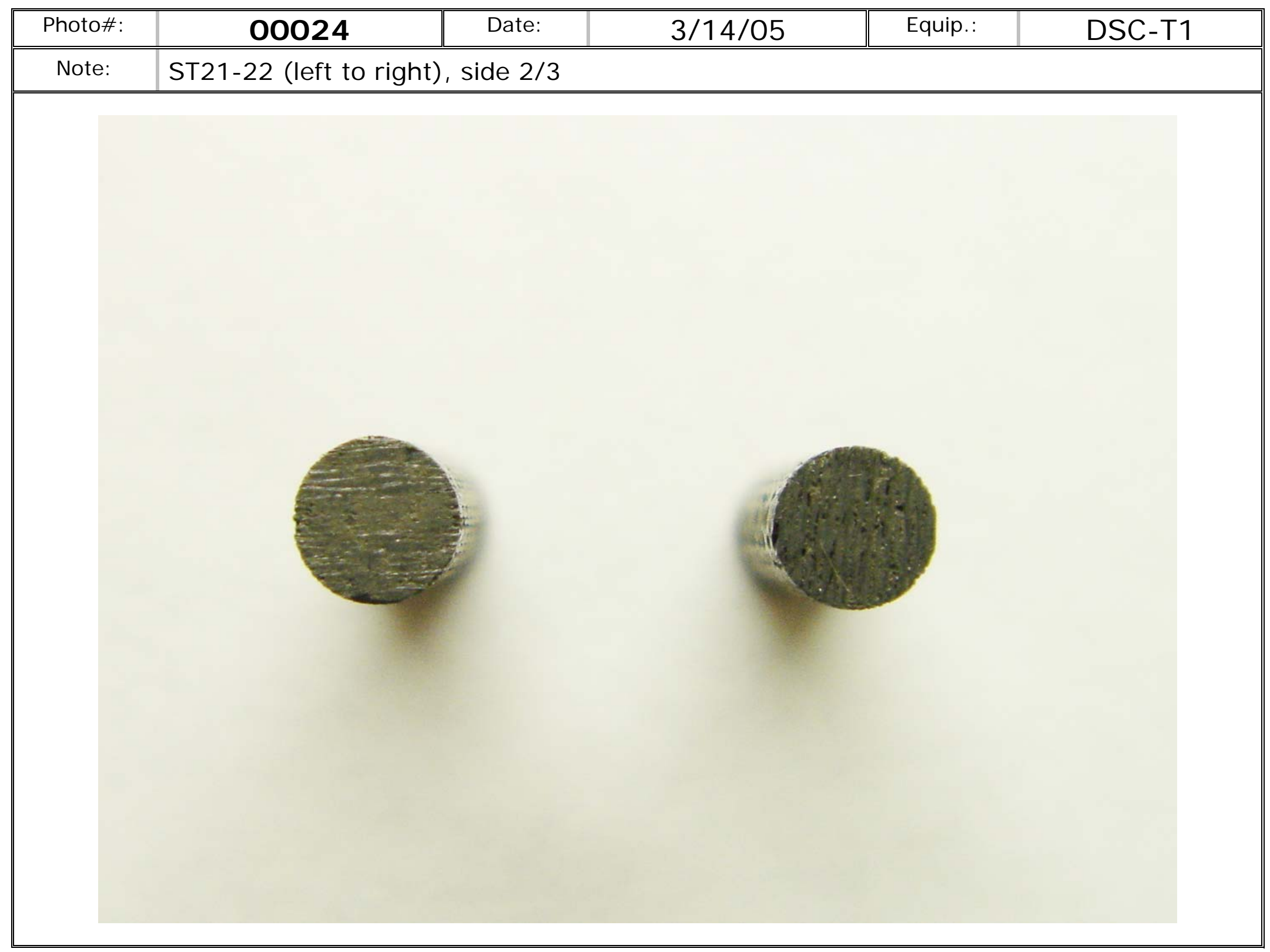

F54 
File: A6_Futurix-MI_ORNL_Specimen_Photos

Printed 5/ 9/ 2005 Page 55 / 76

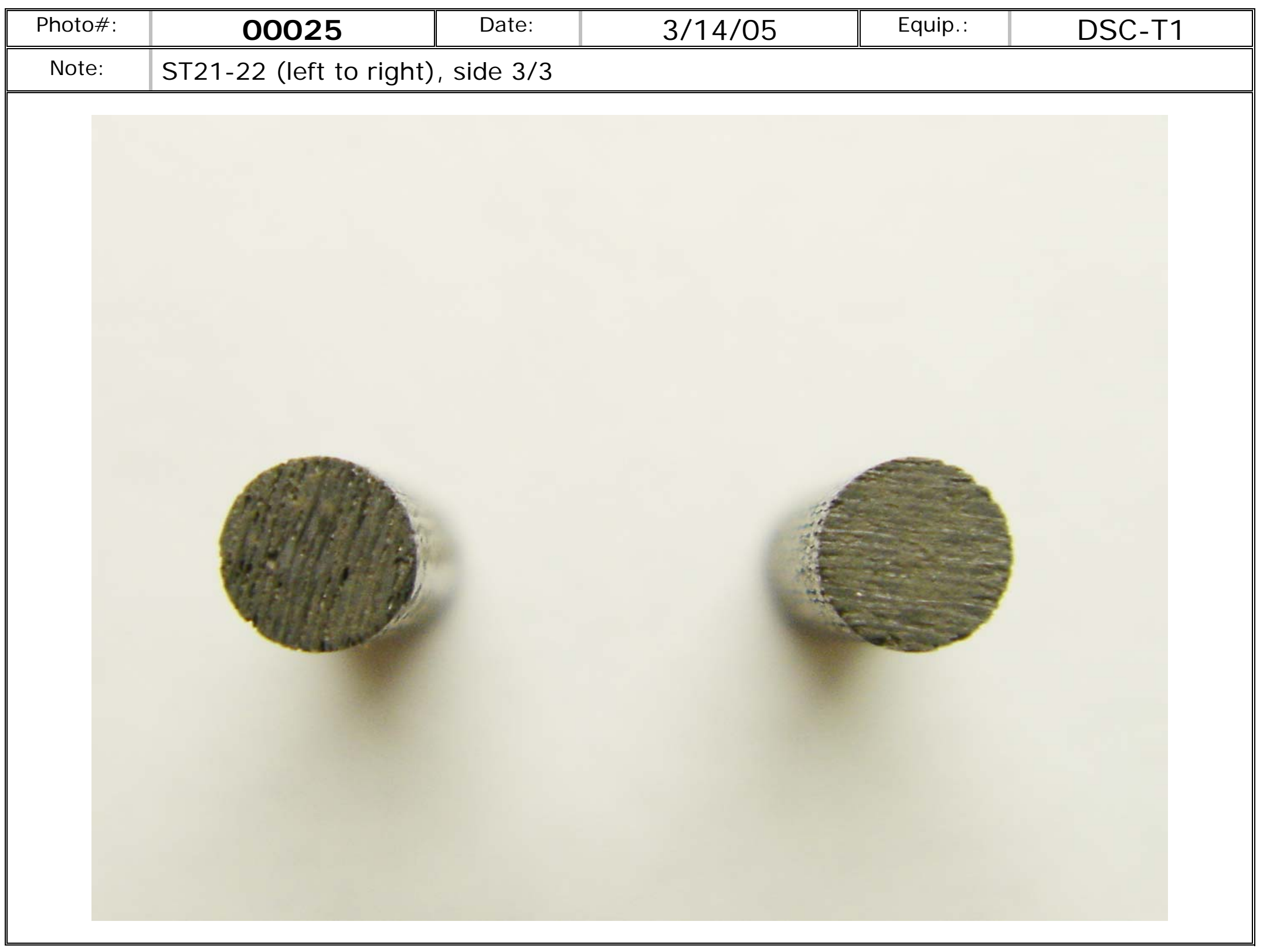

F55 


\begin{tabular}{|c|c|c|c|c|c|}
\hline Photo\#: & $\mathbf{0 0 0 0 5}$ & Date: & $3 / 14 / 05$ & Equip.: & DSC-T1 \\
\hline \hline Note: & TR31- 34 (left to right), side 1/2 & & \\
\hline \hline
\end{tabular}

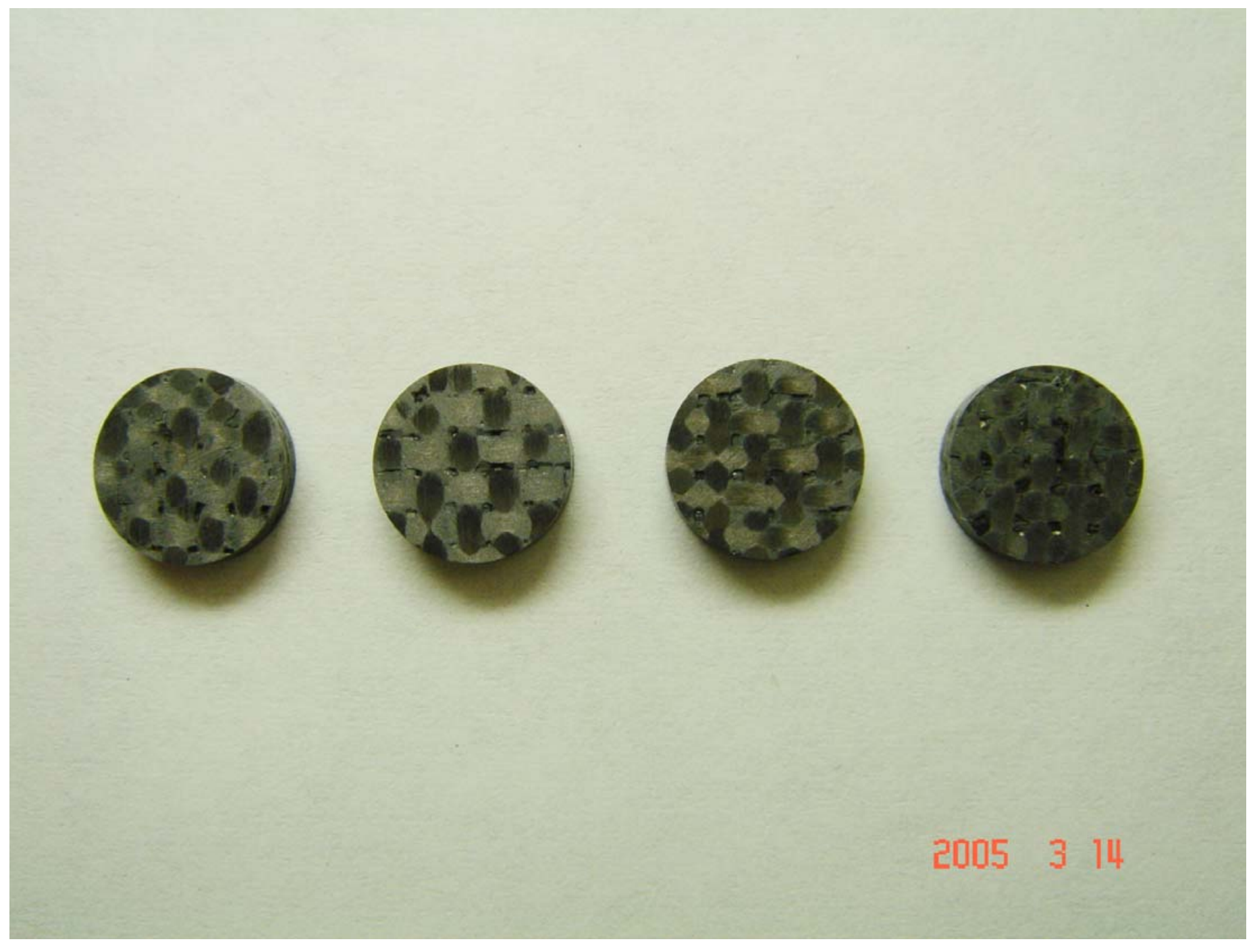




\begin{tabular}{|c|c|c|c|c|c|}
\hline Photo\#: & $\mathbf{0 0 0 0 6}$ & Date: & $3 / 14 / 05$ & Equip.: & DSC-T1 \\
\hline \hline Note: & TR31- 34 (left to right), side 2/2 & & \\
\hline \hline
\end{tabular}

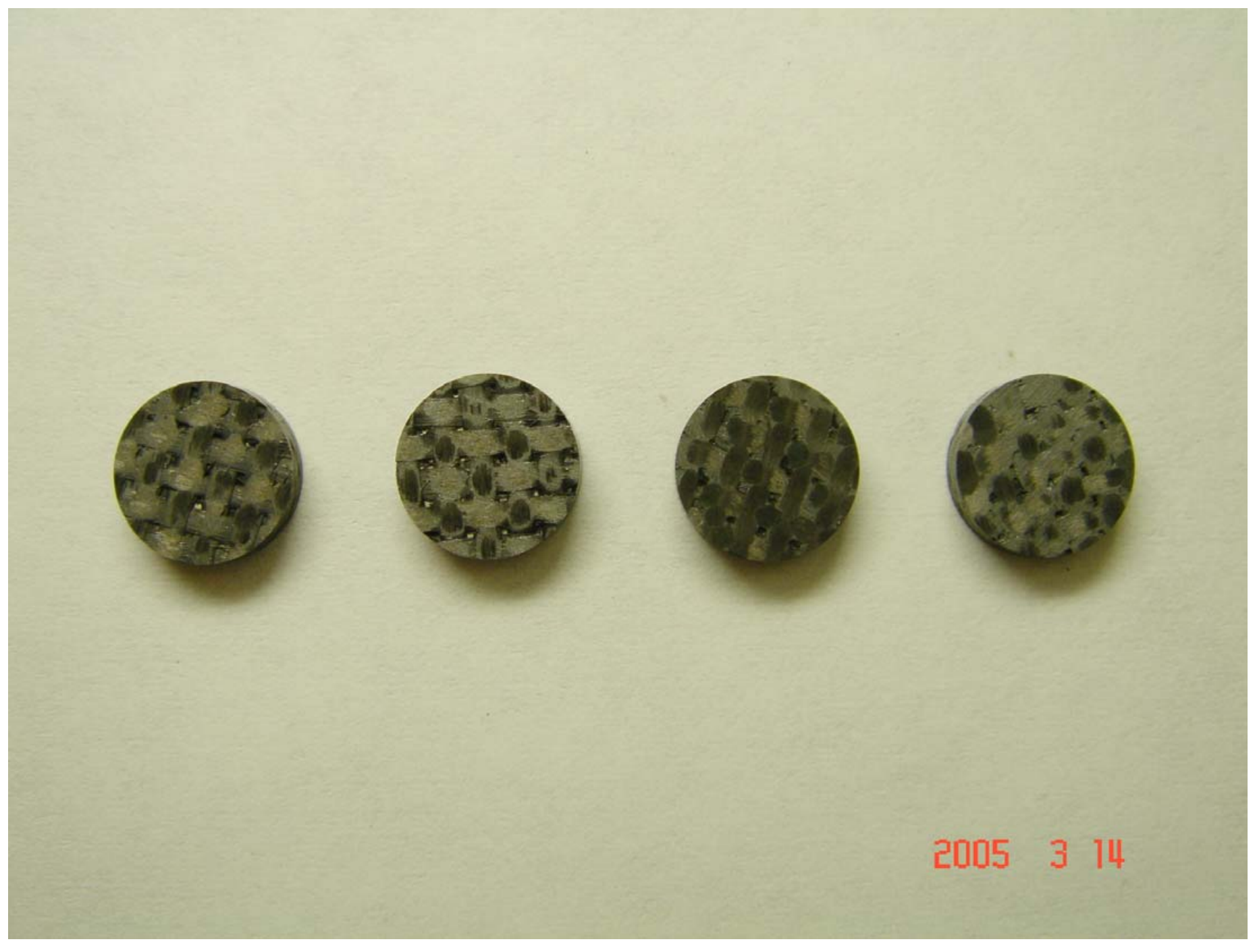




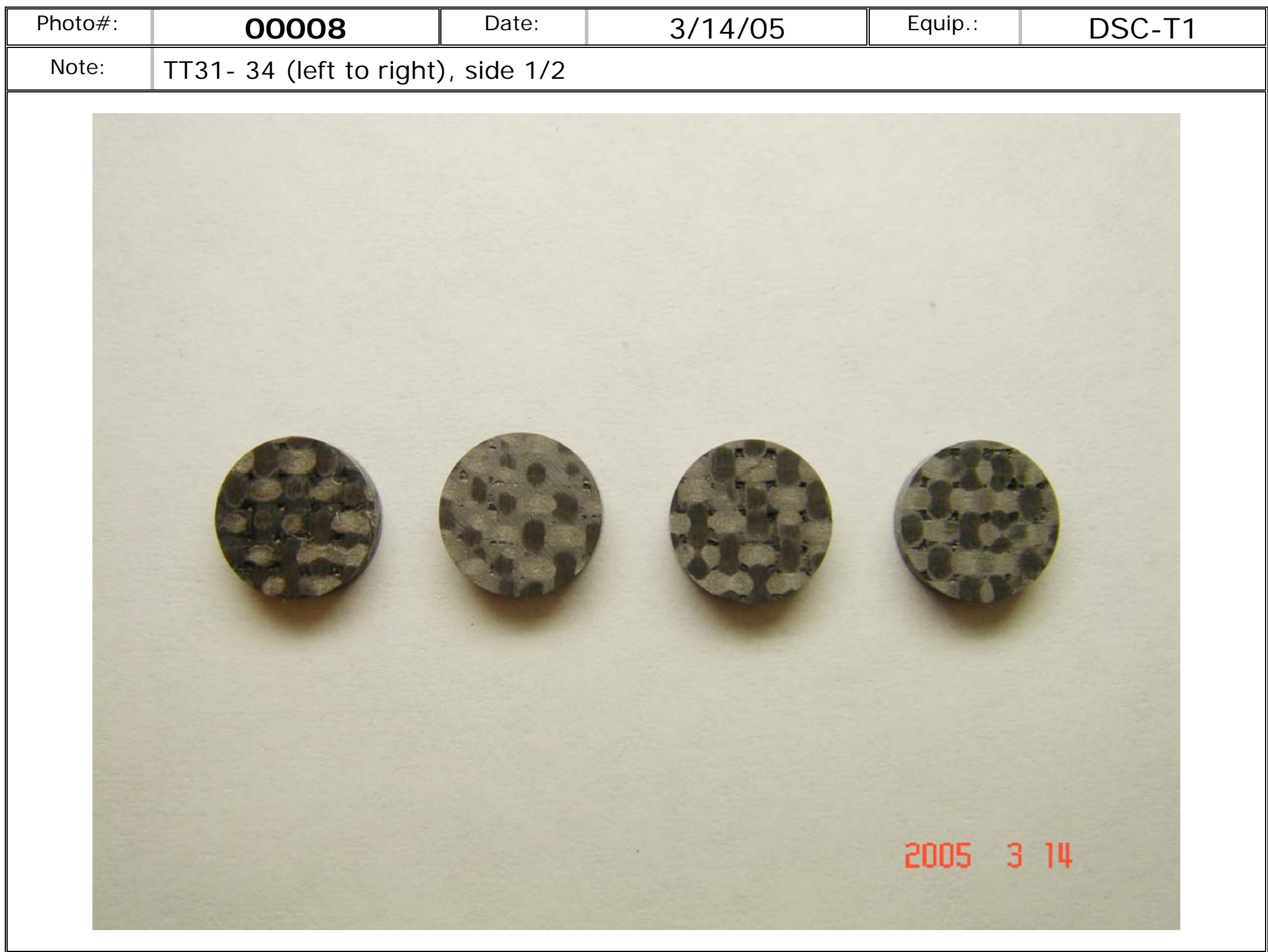




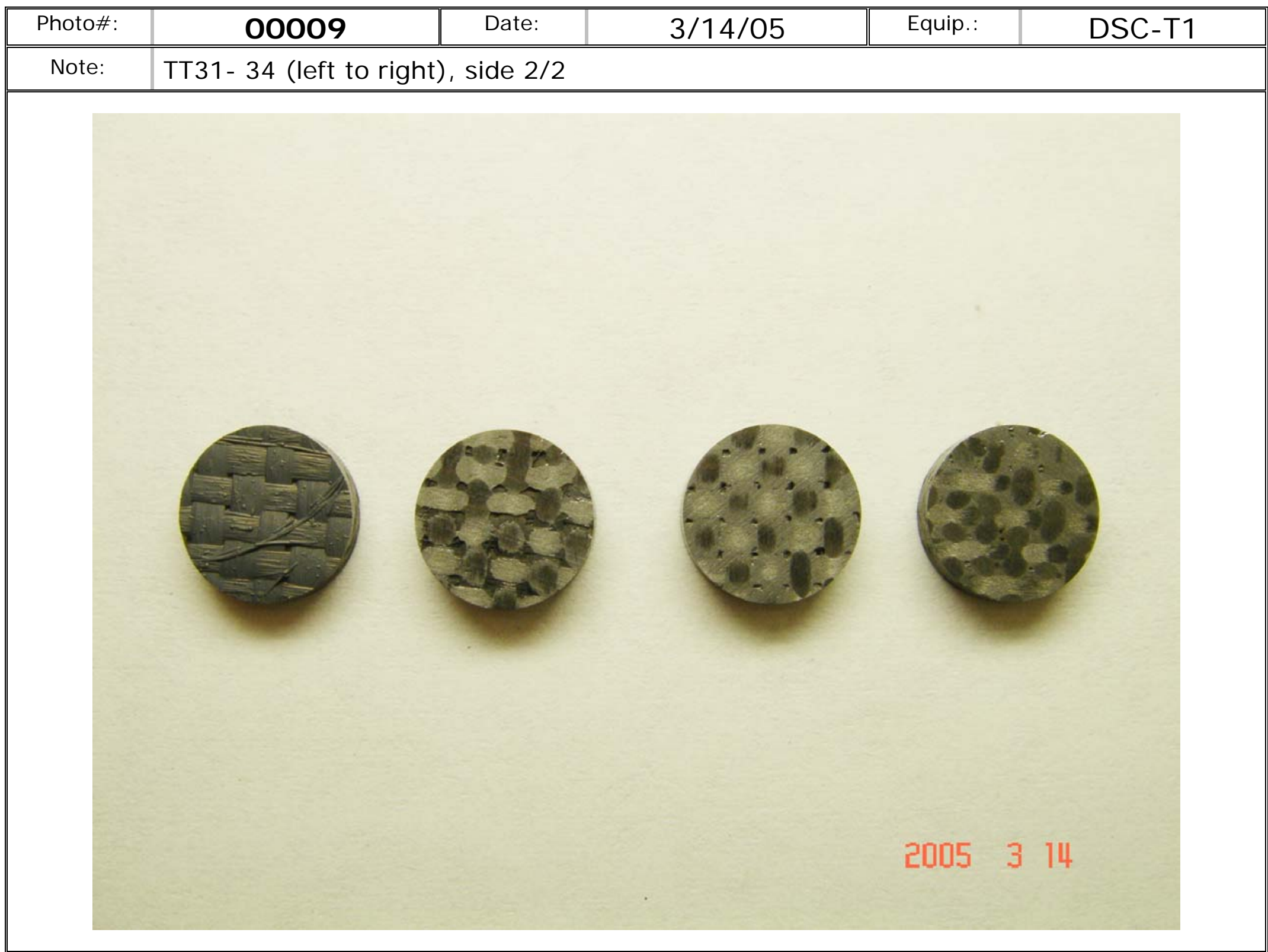




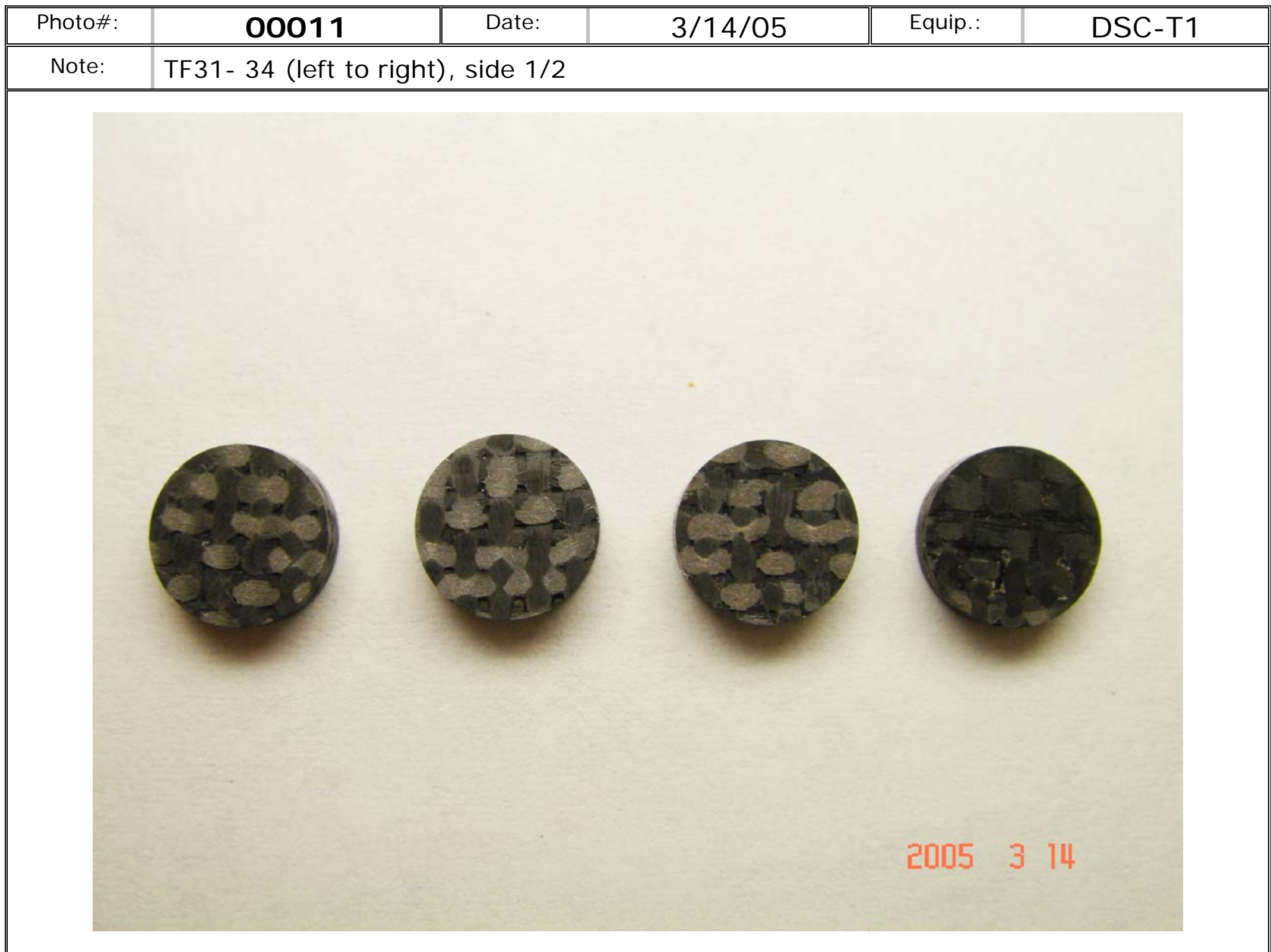




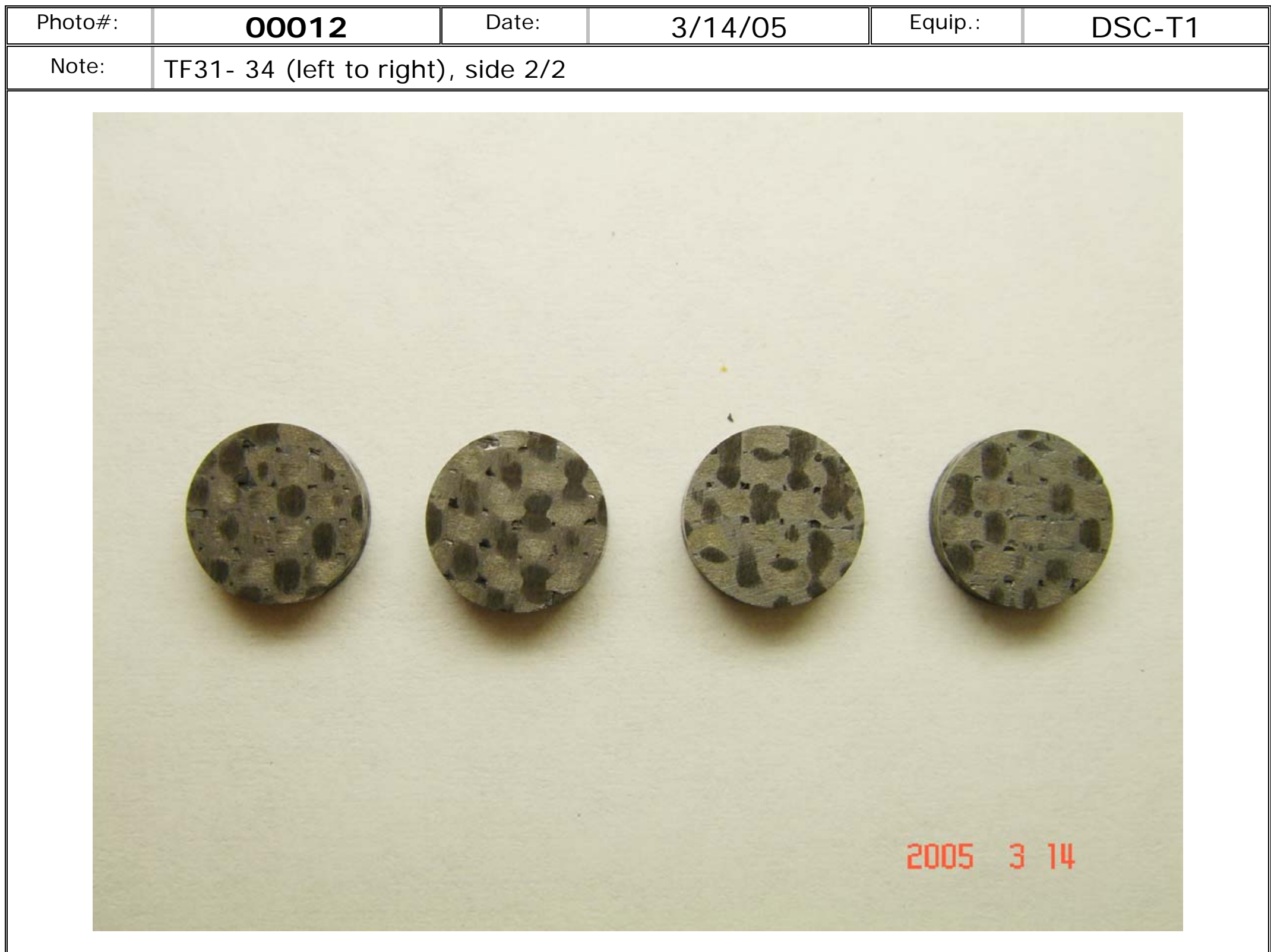




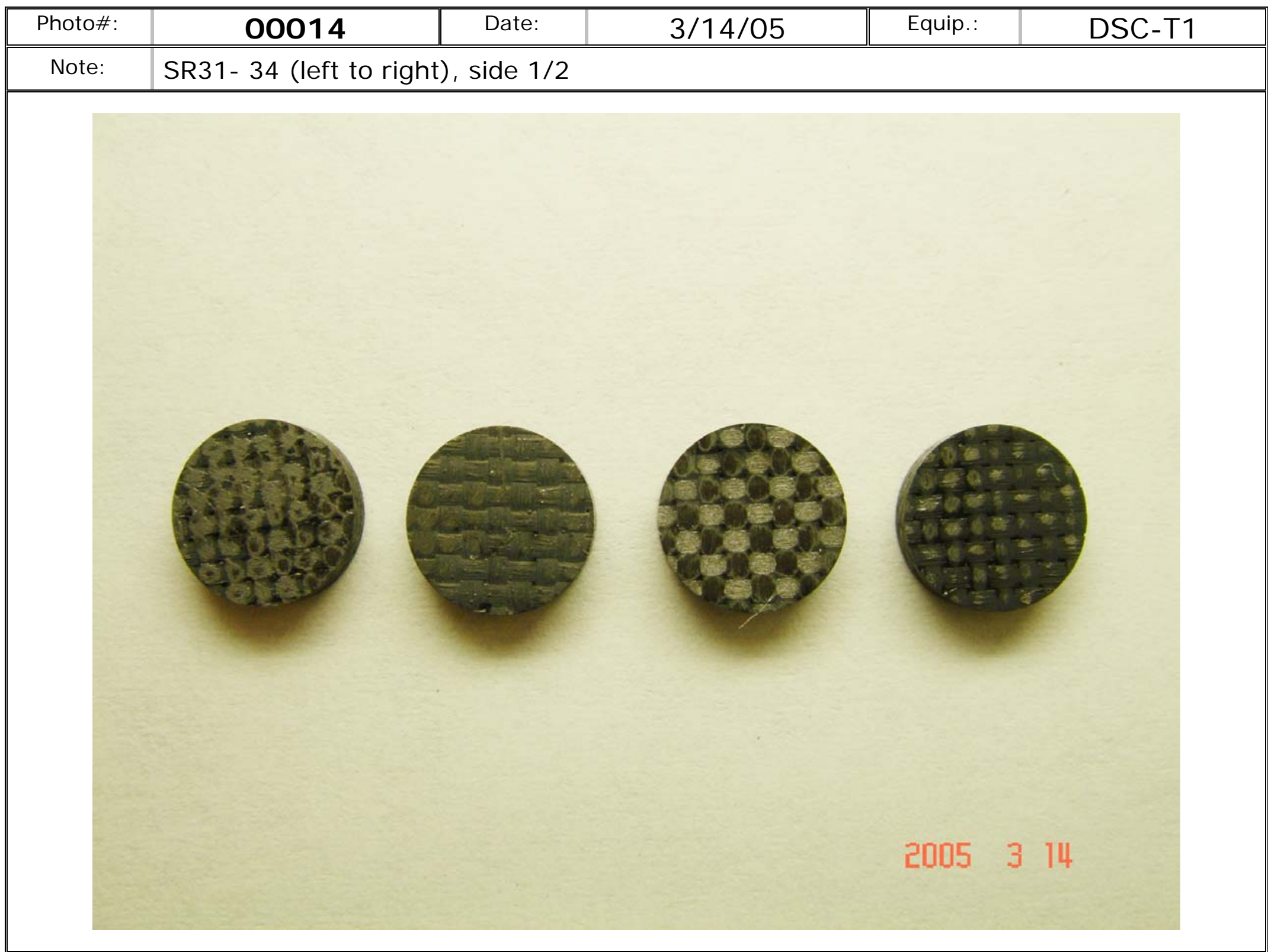




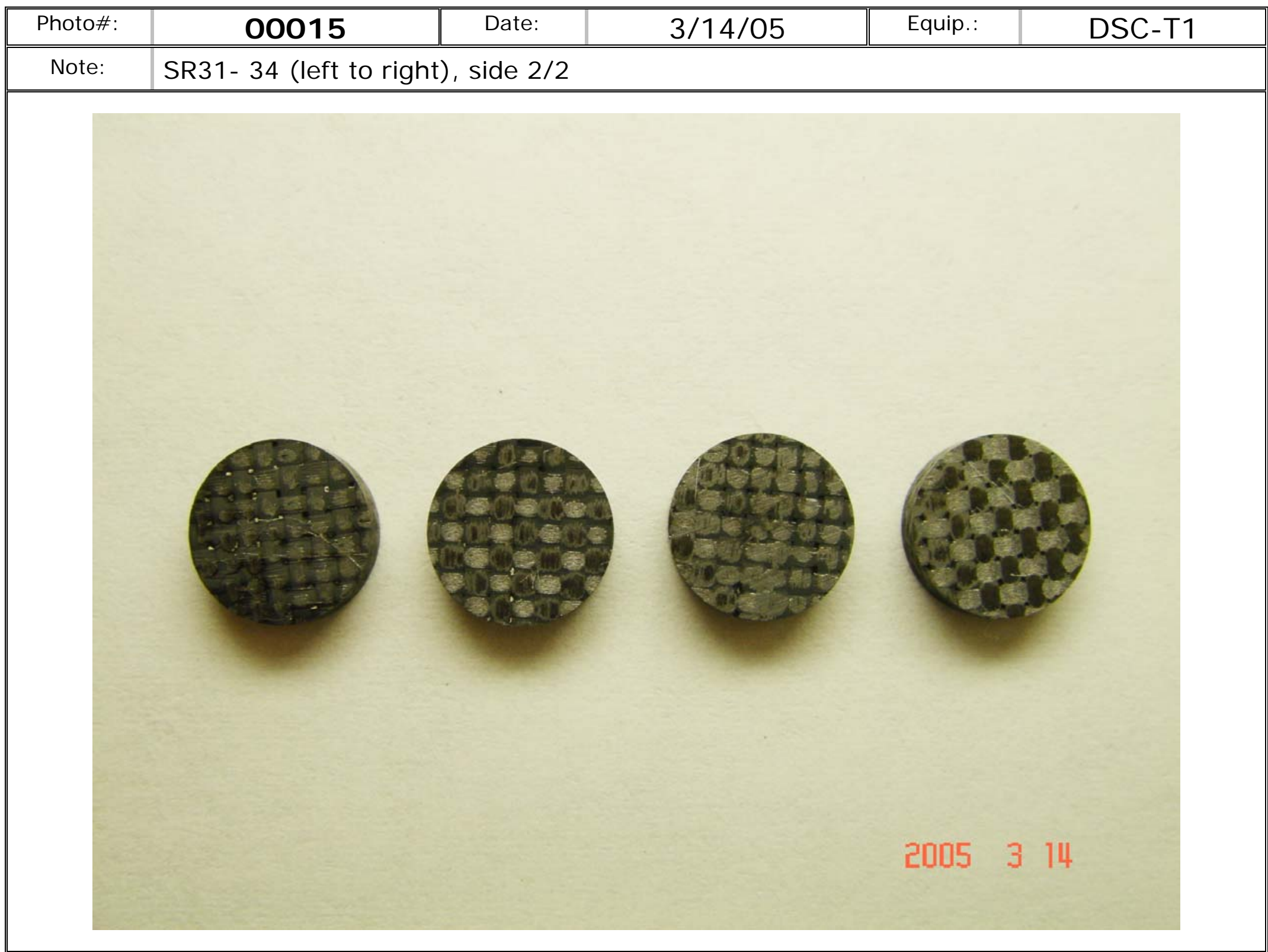




\begin{tabular}{|c|c|c|c|c|c|}
\hline Photo\#: & $\mathbf{0 0 0 1 7}$ & Date: & $3 / 14 / 05$ & Equip.: & DSC-T1 \\
\hline \hline Note: & ST31- 34 (left to right), side $1 / 2$ & & \\
\hline \hline
\end{tabular}

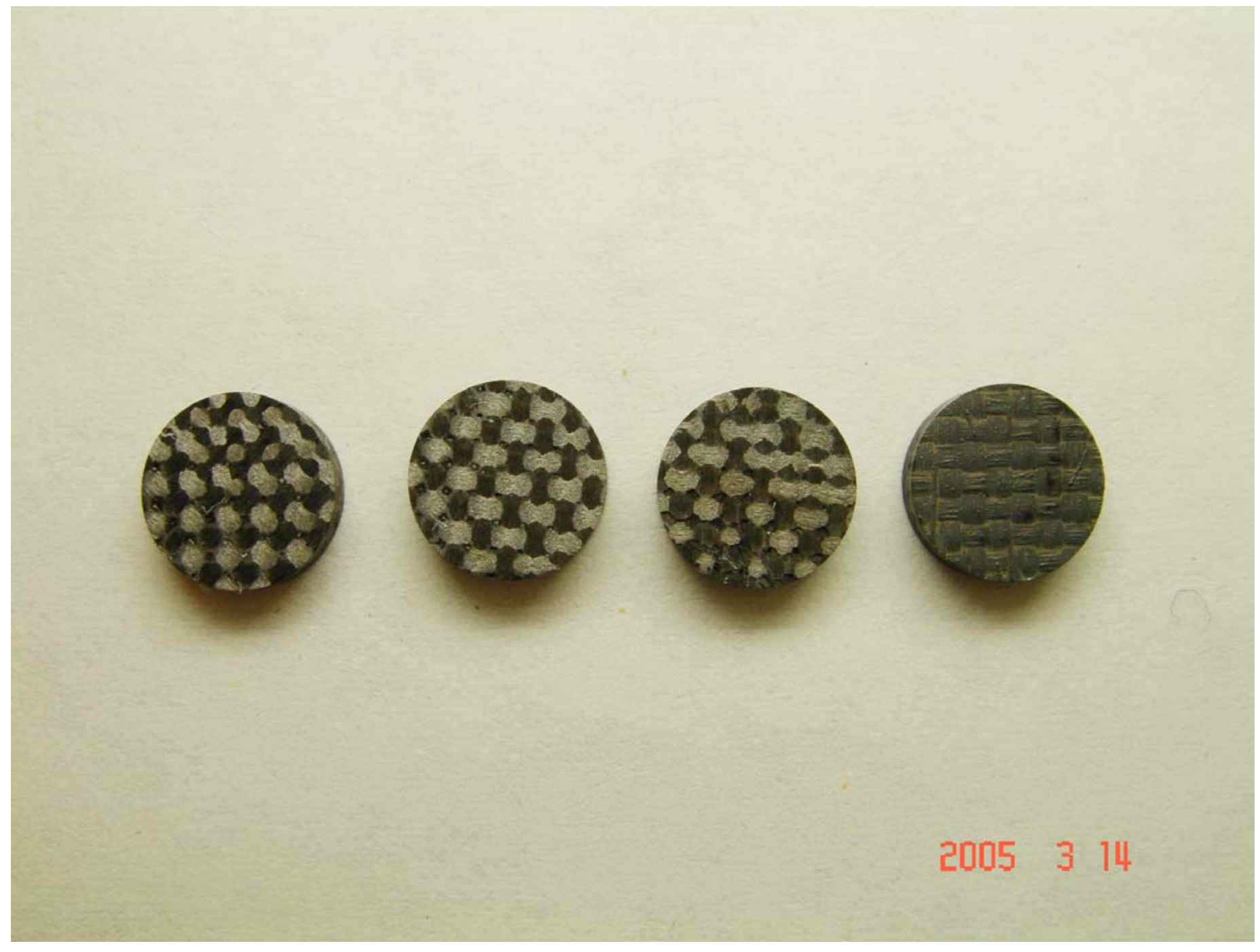




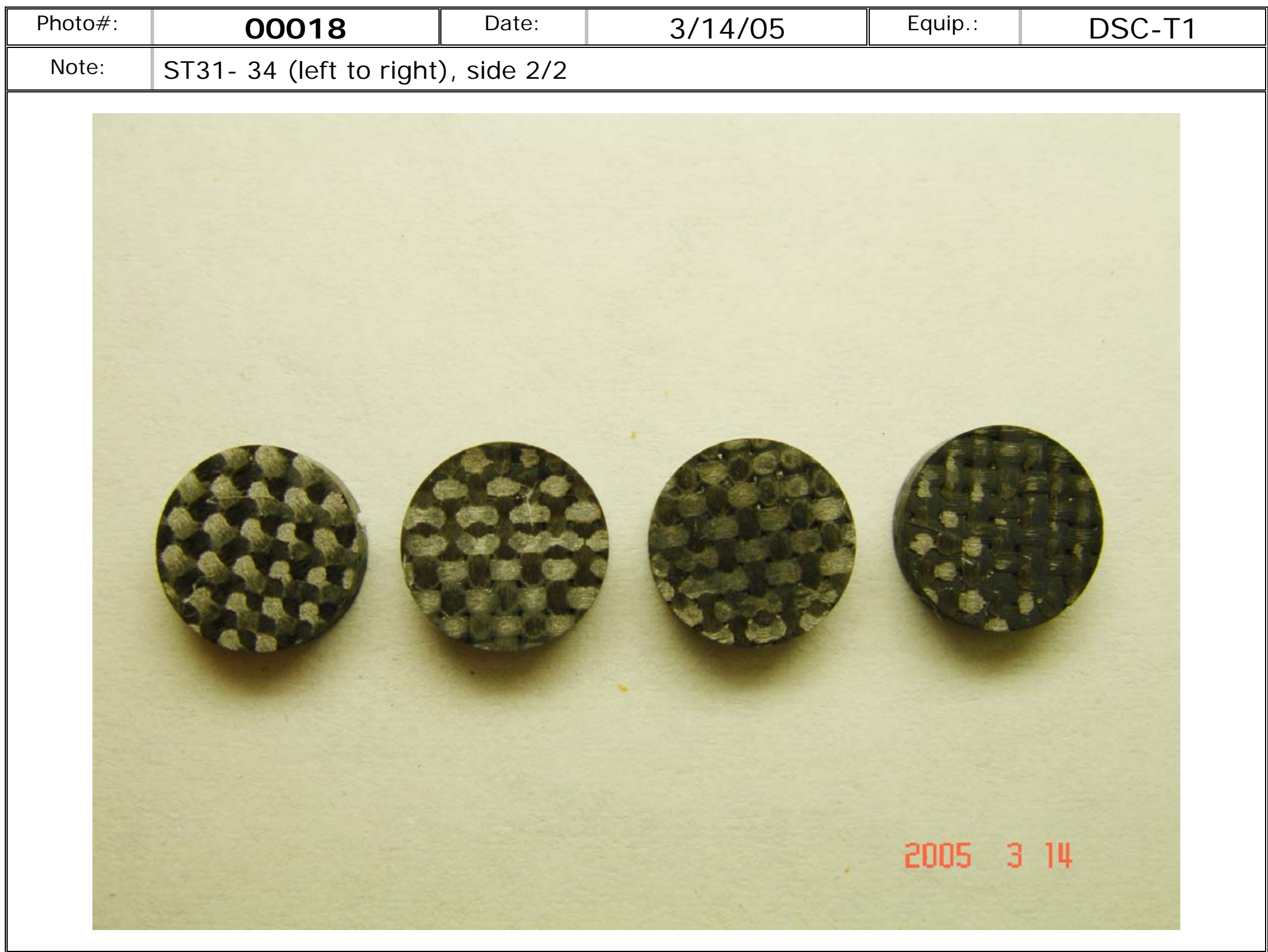




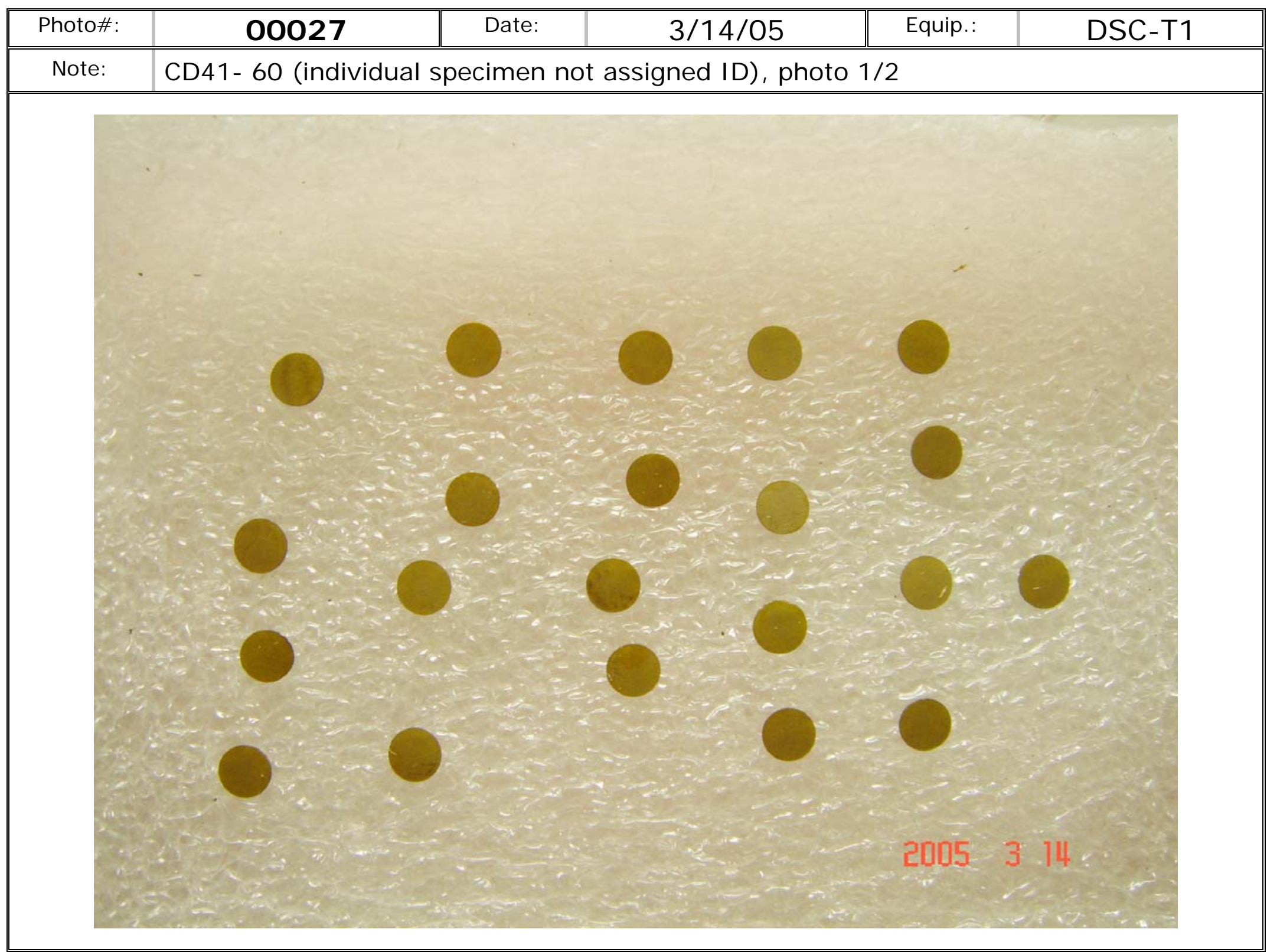




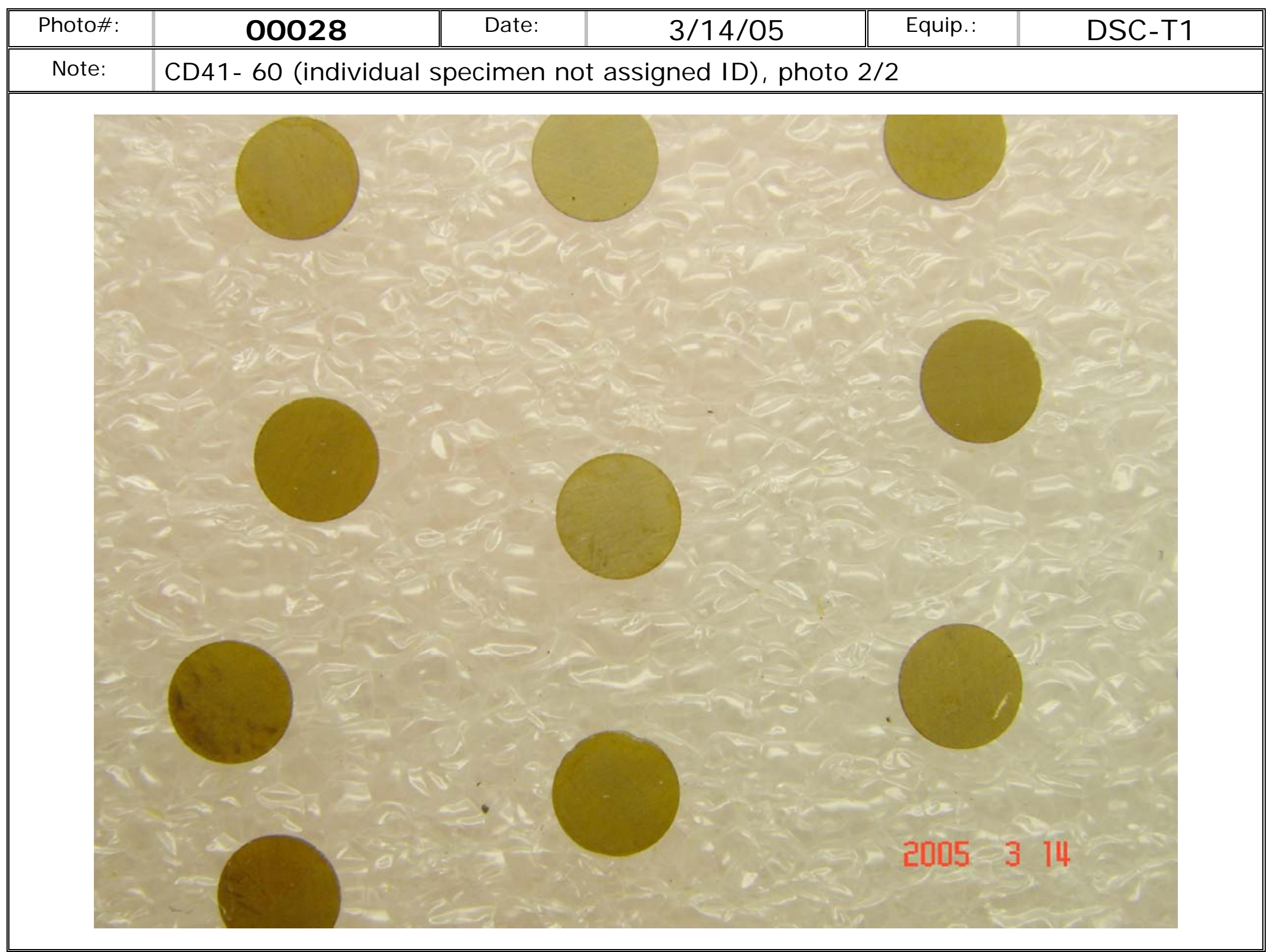


File: A6_Futurix-MI_ORNL_Specimen_Photos

Printed 5/ 9/ 2005 Page 68 / 76

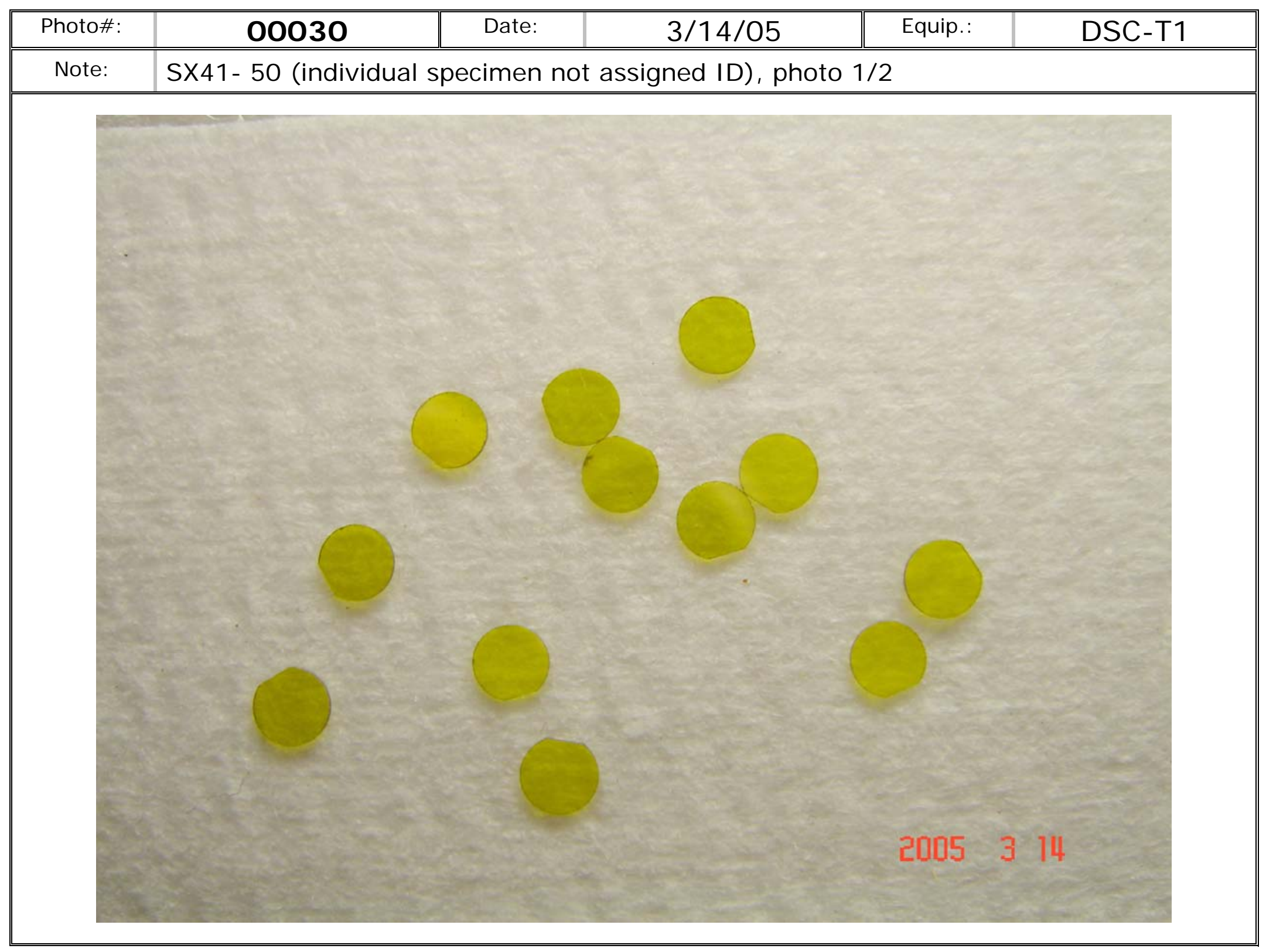

F68 
File: A6_Futurix-MI_ORNL_Specimen_Photos

Printed 5/ 9/2005 Page 69 / 76

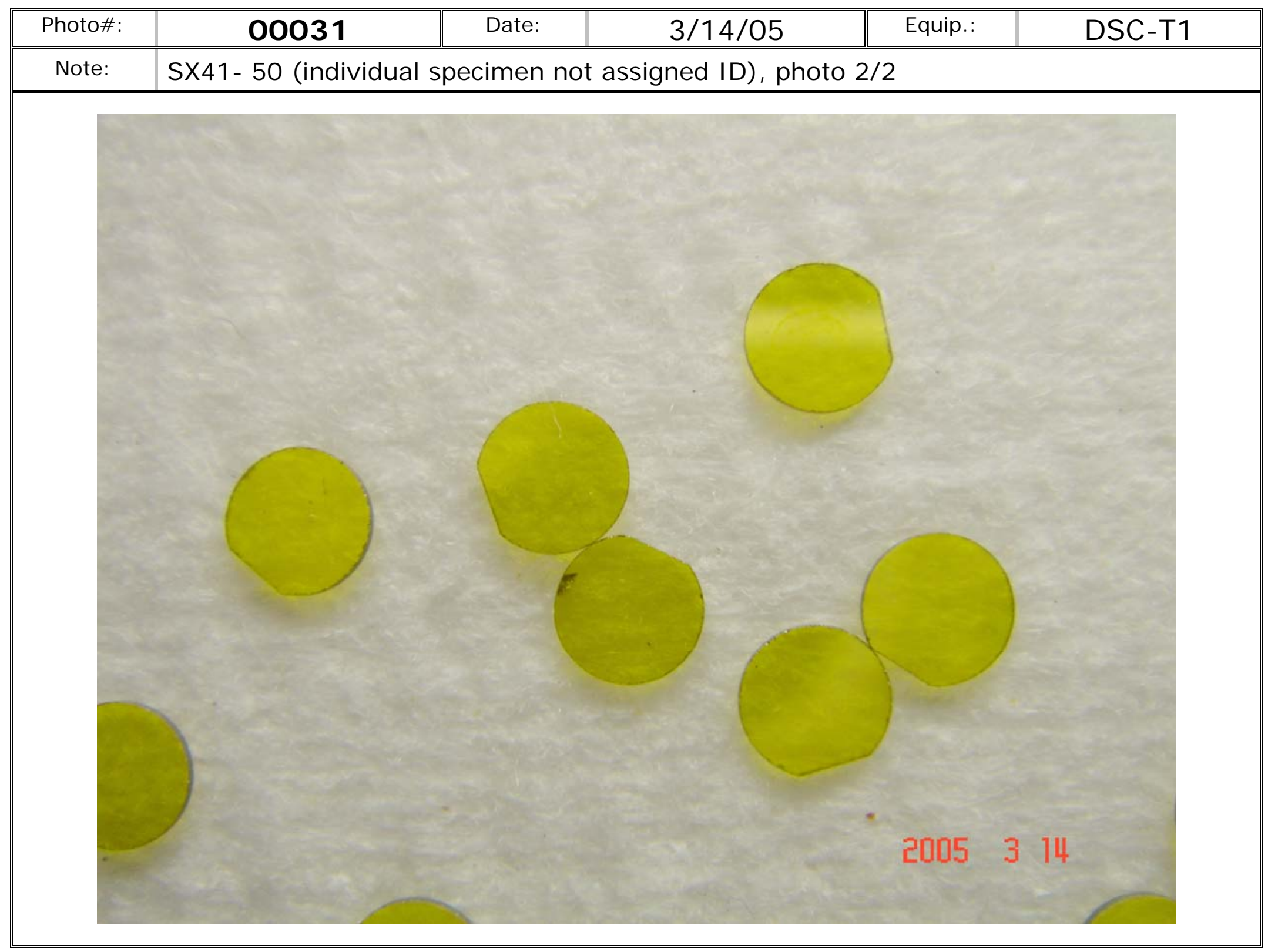

F69 


\begin{tabular}{|c|c|c|c|c|c|}
\hline Photo\#: & $\mathbf{0 0 1 0 7}$ & Date: & $4 / 12 / 05$ & Equip.: & DSC-T1 \\
\hline \hline Note: & L01-32 (see engraved ID), photo $1 / 1$ & & \\
\hline \hline
\end{tabular}

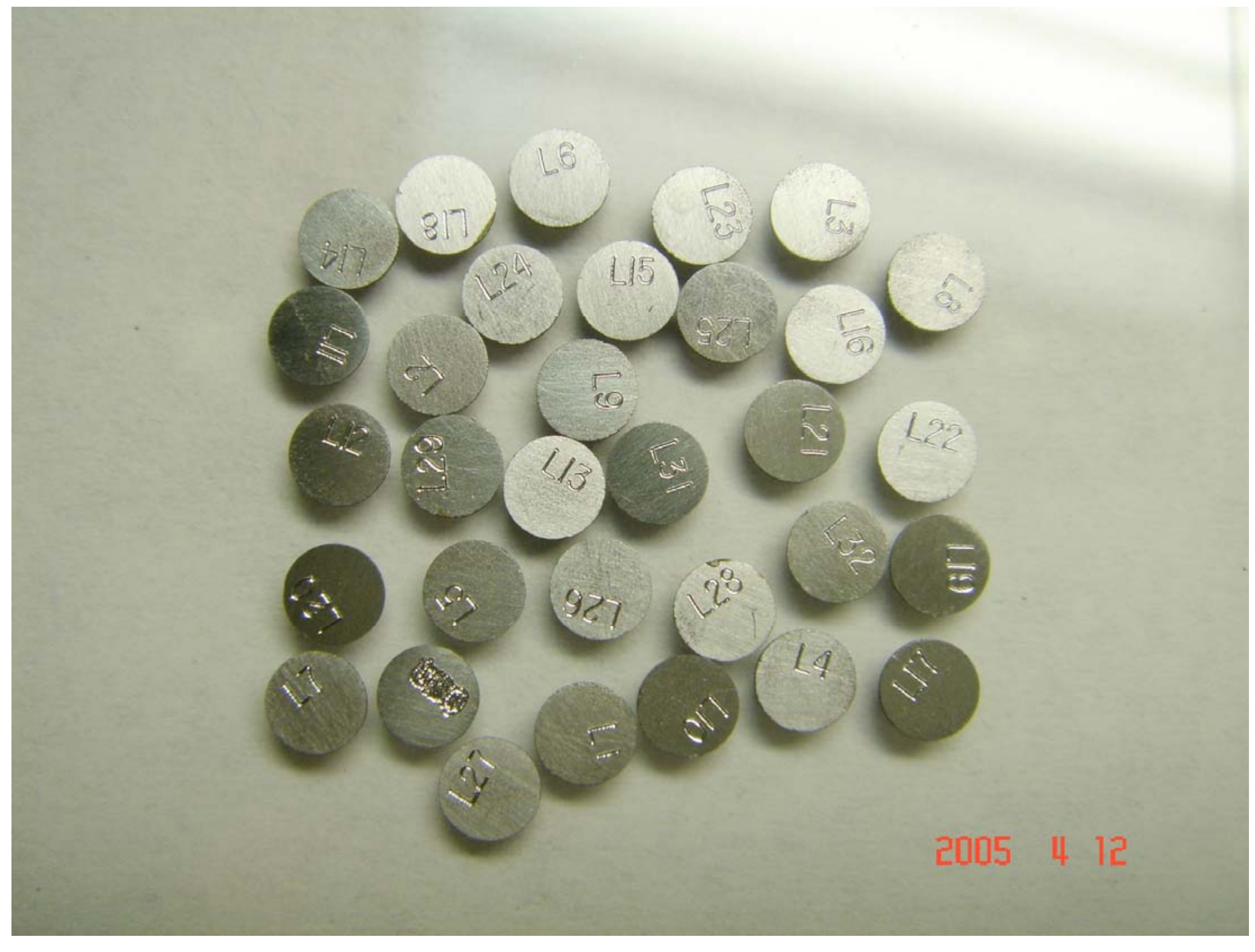




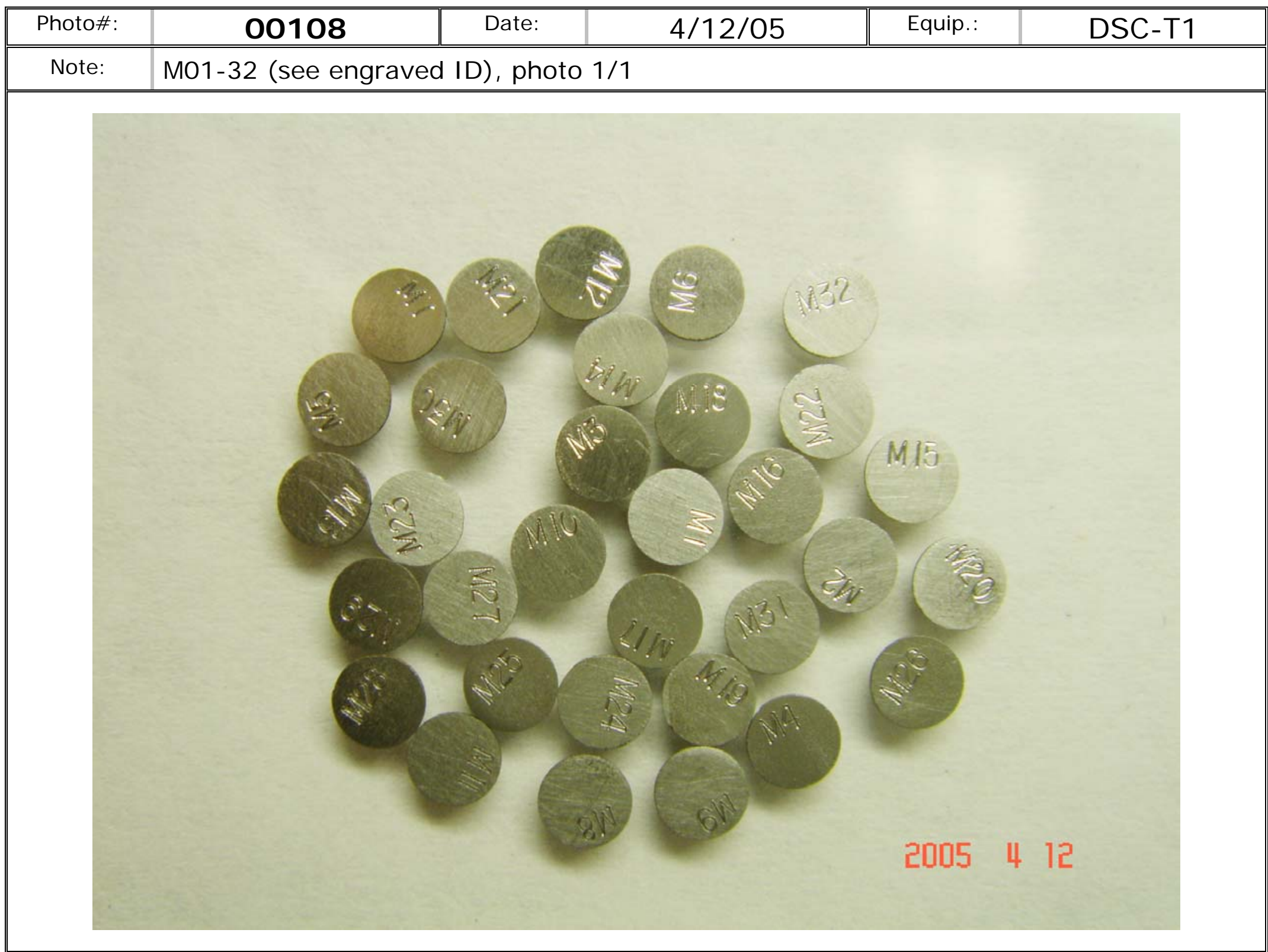




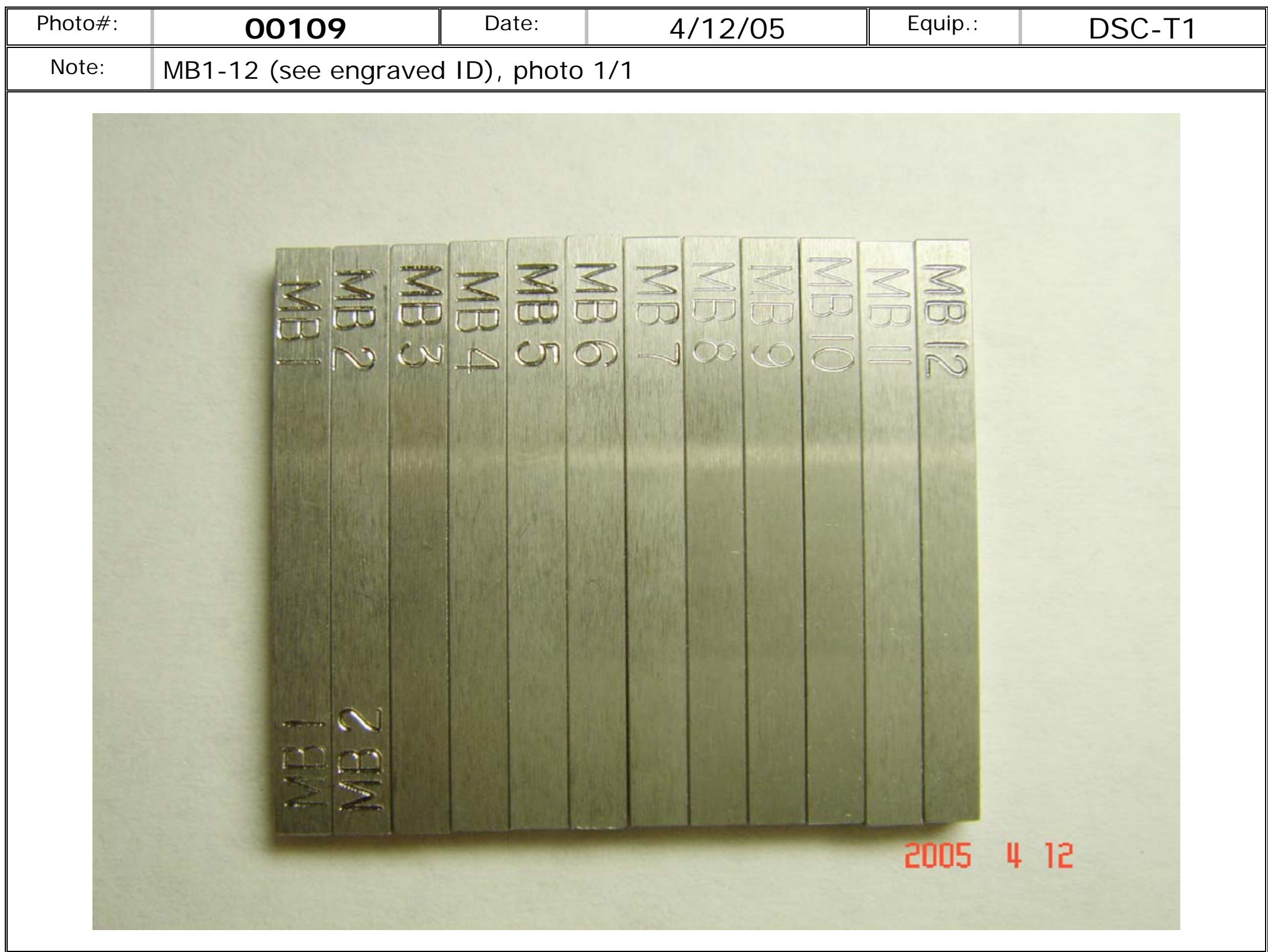




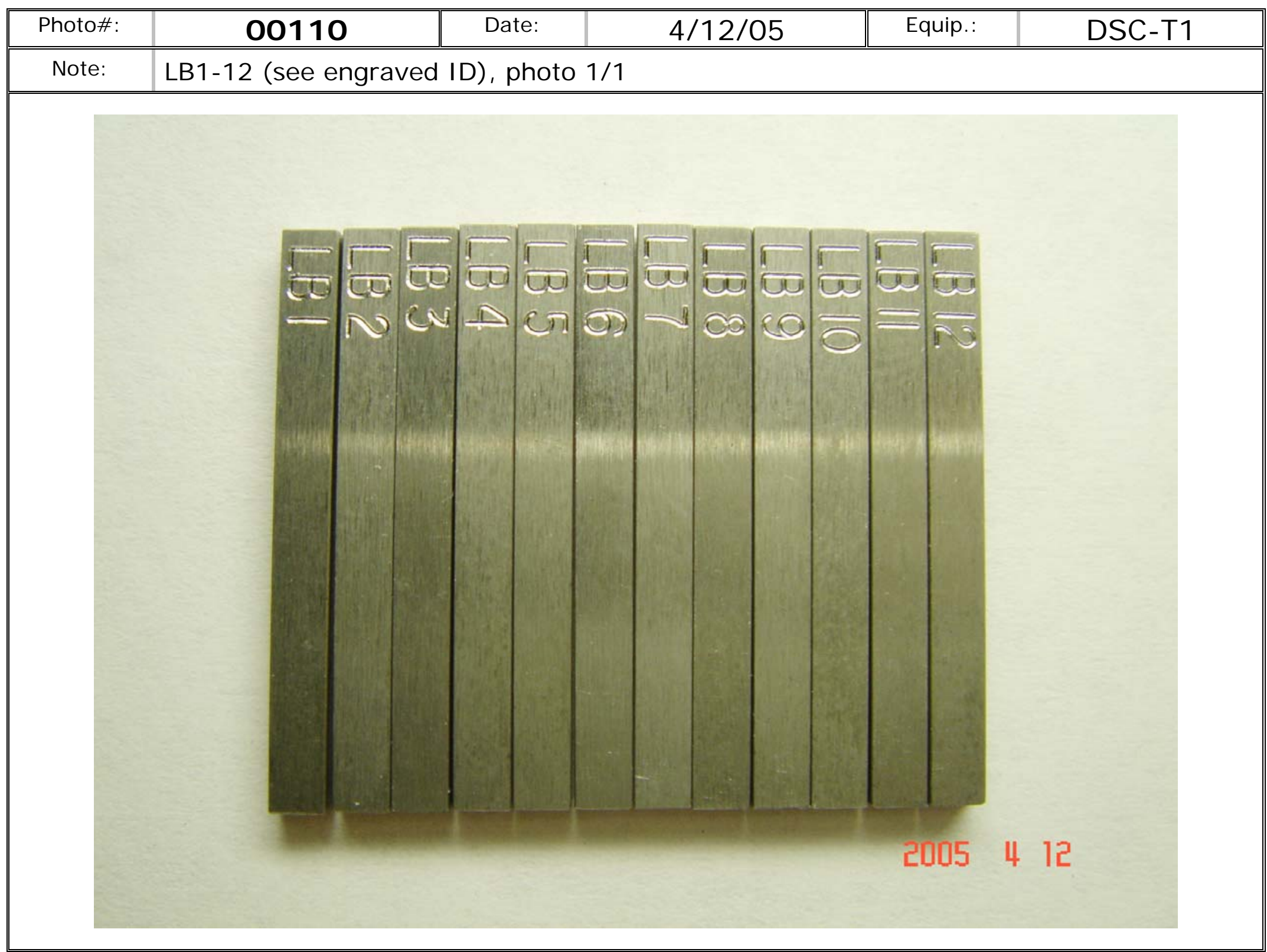




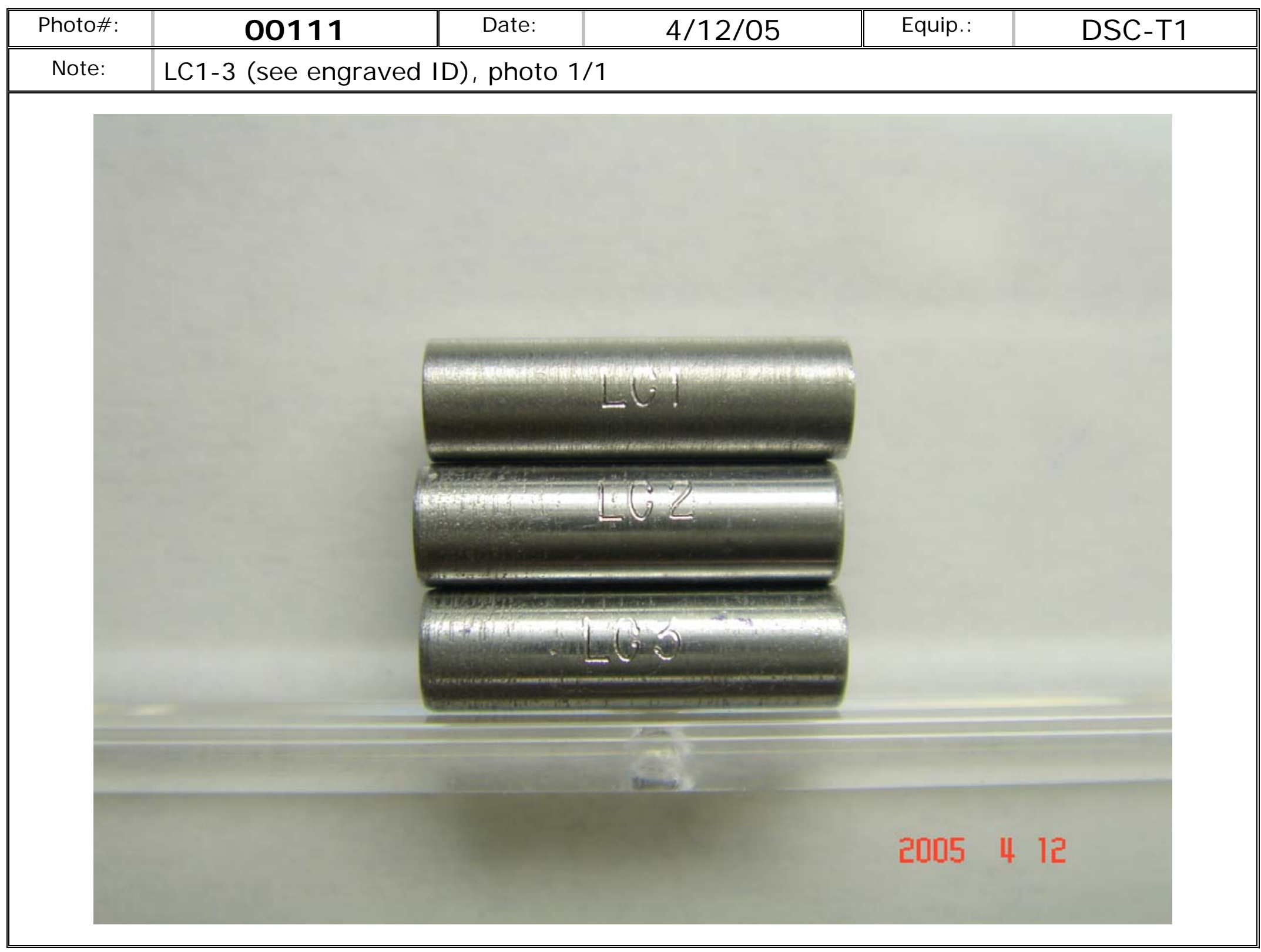




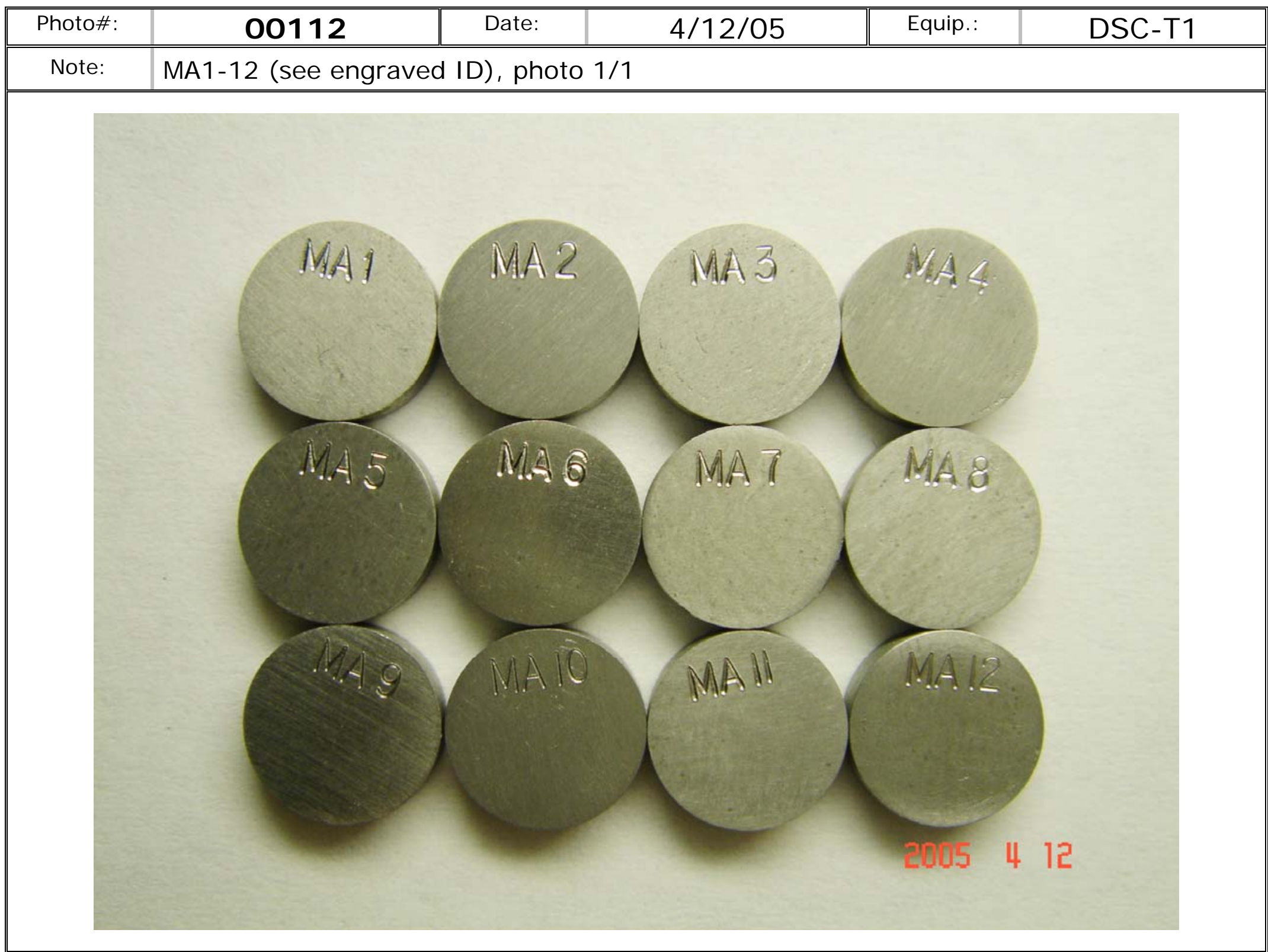




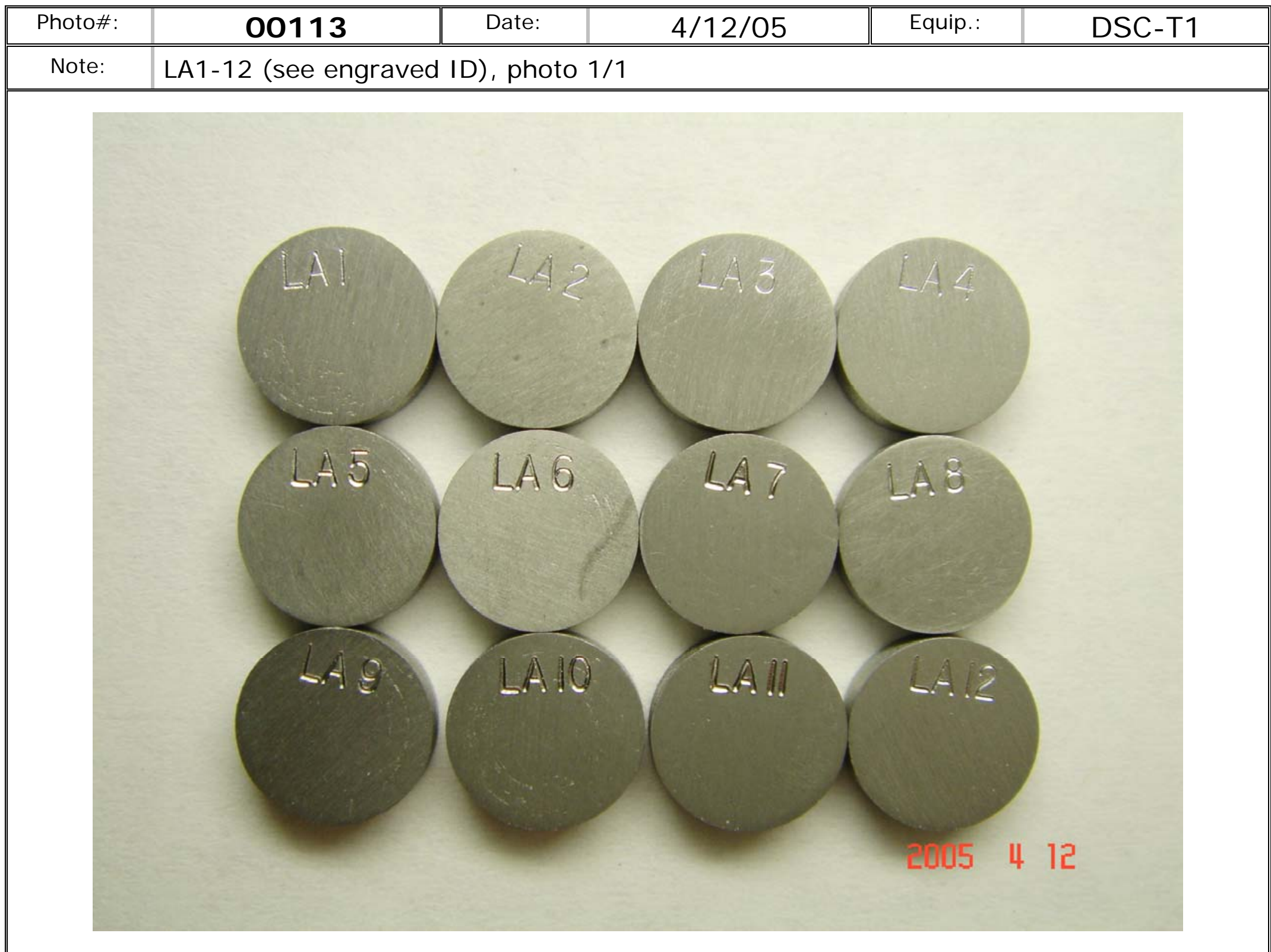

